UNIVERSIDADE DE SÃO PAULO

FACULDADE DE FILOSOFIA, LETRAS E CIÊNCIAS HUMANAS DEPARTAMENTO DE TEORIA LITERÁRIA E LITERATURA COMPARADA

LAURA PENNA ALVES

\title{
Considerações sobre estudos literários em meados de 1970
}

(versão corrigida) 
UNIVERSIDADE DE SÃO PAULO

FACULDADE DE FILOSOFIA, LETRAS E CIÊNCIAS HUMANAS DEPARTAMENTO DE TEORIA LITERÁRIA E LITERATURA COMPARADA

\section{Considerações sobre estudos literários em meados de 1970}

(versão corrigida)

Dissertação apresentada à Faculdade de Filosofia, Letras e Ciências Humanas da Universidade de São Paulo como requisito para a obtenção do título de mestre em Letras. Área de concentração: Teoria Literária e Literatura Comparada.

Orientador: Prof. Dr. Roberto Zular.

São Paulo 


\section{FOLHA DE APROVAÇÃO}

Laura Penna Alves

Considerações sobre os estudos literários em meados de 1970.

Dissertação apresentada à Faculdade de Filosofia, Letras e Ciências Humanas da Universidade de São Paulo como requisito para a obtenção do título de mestre em Letras. Área de concentração: Teoria Literária e Literatura Comparada.

Orientador: Prof. Dr. Roberto Zular

Aprovada em:

\section{Banca Examinadora}

Prof. Dr. Roberto Zular

Faculdade de Filosofia, Letras e Ciências Humanas da Universidade de São Paulo.

Prof. D. João Adolfo Hansen

Faculdade de Filosofia, Letras e Ciências Humanas da Universidade de São Paulo.

Prof. D. Antonio Alcir Bernardez Pécora

Instituto de Estudos da Linguagem da Universidade Estadual de Campinas. 
A todos os pesquisadores que lutam e lutaram por melhores condições de pesquisa. 


\section{Agradecimentos}

À minha mãe, Liriah Penna, por nunca ter perdido o sotaque baiano. Esse trabalho é fruto, antes de mais nada, do seu esforço em criar suas filhas trabalhando muito, com amor e inteligência. Mãe, esse trabalho é uma imitação ínfima da sua grande força, espero que ele faça jus à sua trajetória.

À minha irmã, Maíra Penna, essa segunda mãe com quem fui premiada e que sempre teve palavras de apoio e de incentivo para tudo em que me arrisquei que era verossímil. Mati, esse trabalho é fruto de boa birra e fincar pé foi coisa que aprendi com você. Também agradeço ao meu cunhado, José Roberto, por antigas conversas, e a minha sobrinha Marina, que vai nascer mês que vem e quero que veja o nome aqui quando crescer e puder ler.

Às minhas tias Marília Penna, Icléia Alves Cury e Marieta Trancoso de Castro. Essas três Marias que tanto me apoiaram em momentos difíceis e que foram fundamentais na construção da minha auto-confiança.

Às minhas amigas, Juliana e Fernanda, sempre dispostas a mudar de assunto e impor a nulidade dos sensos comuns universitários. Obrigada por me permitirem ter um cotidiano de liberdade em relação à pesquisa e vivê-la, ao máximo, como mundo restrito como qualquer outro. Esse trabalho não teria sido possível sem cada uma das brejas que tomamos. Valeu mesmo, para sempre, com carinho, irmãs metralha.

À minha amiga e colega Dalila Pinheiro, pela amizade, pelas discussões e, principalmente, pelo exemplo de resistência ao machismo acadêmico.

À minha amiga e colega Mônica Gama, por tudo e mais um pouco. Num ambiente de extrema competição, encontrei alguém disposto a me ajudar com a pesquisa, sem paternalismo, pelo posicionamento político de que o trabalho acadêmico é coletivo e os textos são um processo de aprendizado do qual nunca podemos nos envergonhar. Mônica, essa pesquisa não teria escapado da insanidade institucional se não fosse você.

Ao meu amigo Rafael Mantovani pela confiança que sempre teve em mim e por cada uma de nossas conversas. Berlim e o Rio Pequeno estarão sempre juntos enquanto forem nossas casas.

Ao professor Roberto Zular, orientador deste trabalho, e aos professores João Adolfo Hansen e Alcir Pécora, integrantes da banca de qualificação desta dissertação e que grandemente contribuíram com sugestões.

Ao meu pai, por ter me dado o exemplo, desde pequena, de que o conhecimento é e sempre será maior do que a universidade, assim como o amor de pai e filha será sempre maior do que a família como instituição burguesa e patriarcal. 
Aos meus avós Lulia Elias Alves e Azarias Alves, em especial à minha avó, com quem pude conviver mais intensamente e cuja memória esteve presente ao longo deste trabalho. Ainda sinto o cheiro da casinha de doce das manhãs em Cássia, saudades.

Ao Júlio, meu 'mais que tudo'. Amor com rimas que não interessam. Assim de mãos dadas, nos seduzimos em cotidiano que vive sempre quebrado. Júlio, este trabalho é seu, para você, com todo amor das infinitudes que existiram e existirão. 
Título: Considerações sobre estudos literários em meados de 1970

\section{Resumo}

Este trabalho examina os estudos literários que se seguem, publicados em meados de 1970: $A$ perversão do trapezista: o romance em Cornélio Penna (1976), de Luiz Costa Lima; Verso Universo em Drummond (1975) de José Guilherme Merquior; Ao vencedor as batatas (1977), de Roberto Schwarz; Fundamentos da investigação literária (1974), de Eduardo Portella e Carlos Drummond de Andrade (1976) de Silviano Santiago. Nosso objetivo é investigar de que modo a produção do conhecimento sobre literatura e a produção do valor literário se deram nesses trabalhos, bem como indicar algumas transformações no campo literário naquele período.

Palavras chaves: teoria literária, campo literário, estudos literários, Luiz Costa Lima, José Guilherme Merquior, Roberto Schwarz, Silviano Santiago, Eduardo Portella 


\section{Título: Considerations on literary studies in the mid-1970s}

\section{Abstract}

This academic work examine the literary studies that follows, all published in the mid-1970s: A perversão do trapezista: o romance em Cornélio Penna (1976), by Luiz Costa Lima; Verso Universo em Drummond (1975), by José Guilherme Merquior; Ao vencedor as batatas (1977), by Roberto Schwarz; Fundamentos da investigação literária (1974), by Eduardo Portella e Carlos Drummond de Andrade (1976), by Silviano Santiago. Our purpose is to investigate how the production of knowledge about literature and the production of literay value is given in this work, as well as indicate somes changes in the literary field in that period.

Keywords: literary theory, literary field, literary studies, Luiz Costa Lima, José Guilherme Merquior, Roberto Schwarz, Silviano Santiago, Eduardo Portella 


\section{Sumário}

1. Introdução 9

1.1 Segundas intenções com um terceiro elemento 9

$\begin{array}{lll}1.2 & \text { Percurso de um caminho } & 15\end{array}$

2. Reflexões sobre as transformações universitárias de 1960 e 1070 e a ideia $\begin{array}{ll}\text { de campo literário } & 17\end{array}$

2.1 As lutas por autonomia e as transformações universitárias $\quad 17$

2.2 A atribuição do adjetivo nacional ao termo campo literário 26

2.3 A relatividade da autonomia na compreensão simbólica das transformações universitárias. 36

3. As tomadas de posição em relação à teoria literária e à estética. 43

3.1 Caso a caso 46

$\begin{array}{lll}3.2 & \text { Observações gerais } & 75\end{array}$

4. As tomadas de posição em relação ao valor literário 80

4.1 O gesto de falar sobre $\quad 83$

4.2 Caso a caso 95

$\begin{array}{lll}4.3 & \text { Observações gerais } & 116\end{array}$

$\begin{array}{ll}\text { 5. Considerações finais } & 118\end{array}$

$\begin{array}{ll}\text { Bibliografia } & 121\end{array}$ 


\subsection{Introdução}

\subsection{Segundas intenções com um terceiro elemento}

O modo como compreendemos a temporalidade do objeto que aqui construímos não é entendido como pretensamente neutro e em relação de empatia com o que seria o "espírito" da época a que pertence. Nesse sentido, não caberia aqui uma tentativa artificial de trazer o "clima da época" antes de entrar no assunto que seria relevante. Apesar de comum aos estudos literários que se debruçam sobre o período de 1960 e 1970, tentaremos fugir da construção de um "clima da época", pensando, antes de mais nada, no modo como naquele tempo existiu uma autorrepresentação histórica que tornou aquele momento presente de diferentes formas até os dias de hoje. Sobre a presença dessas décadas nas que se seguiram fenômeno que ultrapassou as fronteiras nacionais e estaria em diferentes âmbitos -, Irene Cardoso (2005, p.4) diz que isso faz parte do modo idealista como tem circulado a herança da chamada "geração dos anos 1960":

ao se congelar em uma unidade imaginária, [...] preservam o que seria seu menor denominador comum, ao mesmo tempo em que perdem sua historicidade. Esse processo constrói a identidade heróica de uma geração, cujo peso para as gerações posteriores tem sido considerável, senão desmedido.

Tentando contribuir para um esforço geral de arejamento de uma visão idealizada deste passado e, portanto, do presente dos estudos literários, cremos ser interessante experimentar outras categorias de compreensão temporal. Aqui empregaremos centralmente a de campo literário, pois, apesar de ser uma metáfora espacial, ela pode ser lida como convívio de diferentes temporalidades das práticas que o constituem: literatura, crítica literária, teses sobre literatura, resenhas literárias, instituições etc., em movimentos de transformações constantes.

\footnotetext{
${ }^{1}$ Segundo a autora, atualmente a geração dos anos 1960 teria entrado para o registro do exótico na medida em que seu lado contestatório submergiu à assimilação pela publicidade. Após algumas décadas, os símbolos dessa geração acabariam associados a um modo de vida apaziguado, e a sua complexa identidade, criada entre movimentos sociais, políticos e culturais, transformou-se em um mito que, enquanto tal, não apresenta possibilidades de "recontextualizações, deslocamentos, redefinições, interpretações, novas questões" (CARDOSO, 2005, p.4). No âmbito da teoria e da crítica literária, João Cezar de Castro Rocha aponta muito bem esse problema em Crítica Literária: em busca do tempo perdido (2011), atendo-se particularmente ao diagnóstico que Terry Eagleton faz em Depois da teoria: um olhar sobre os Estudos Culturais e o pósmodernismo (2005).
} 
No ponto 2.0 desta dissertação, justificaremos a pertinência do emprego desse conceito de campo literário. Por ora, cabe apenas indicar que o conjunto dos estudos literários por nós abordado nos interessa quanto às suas condições de produção, bem como pelas compreensões e valores literários que emprega. Esse conjunto é constituído basicamente dos livros A perversão do trapezista: o romance em Cornélio Penna (1976), de Luiz Costa Lima; Verso Universo em Drummond (1975), de José Guilherme Merquior; Ao vencedor as Batatas (1977), de Roberto Schwarz; Fundamentos da investigação literária (1974), de Eduardo Portella; e Carlos Drummond de Andrade (1976), de Silviano Santiago.

O estado do campo literário nesse momento, bem como o modo de compreensão e valoração dos objetos literários neles, serão tratados separadamente, ainda que estabeleçamos vínculos entre eles. No caso do primeiro, em que há elementos não textuais na construção de nossas hipóteses, esta possibilidade de análise é marcada, antes de tudo, pelo que Bourdieu e Foucault constroem como relação entre o empírico e o transcendental. A divisão entre ambos rejeitaria a presença de um capítulo primeiro sobre campo literário, pois esse soaria como contexto numa tese sobre estudos de crítica e valor literário. Contudo, essa divisão se justifica tanto pela necessidade de exposição e aprofundamento da pesquisa, como porque, pelo contrário, contribui justamente para operar essa aproximação.

No caso de Foucault, em Arqueologia do saber (1972, p.78-79), o filósofo afirma a existência de um âmbito pré-conceitual que, "em lugar de delinear um horizonte que viria do fundo da história e se manteria através dela, é, pelo contrário, ao nível mais 'superficial' (ao nível dos discursos), o conjunto das regras que ali se encontram efetivamente aplicadas" e que "deixa aparecerem as regularidades e coações discursivas que tornaram possível a multiplicidade heterogênea dos conceitos e, mais além ainda, a abundância desses temas, dessas crenças, dessas representações [...]." (grifo nosso). Ora, vejamos que Bourdieu, principalmente em Meditações pascalinas (2001), também afirma a pertinência da investigação do que seriam as condições de possibilidade de uma "gramática de práticas", se podemos dizer assim. No capítulo "Fundamentos históricos da razão", o sociólogo afirma a historicidade radical da razão:

o campo é um lugar de um regime de racionalidade instituído sob a forma de constrangimentos racionais os quais, objetivados e manifestados numa certa estrutura da troca social, encontram a cumplicidade imediata das disposições adquiridas pelos pesquisadores [...] Tais disposições lhes permitem construir o espaço dos possíveis específicos inscritos no campo (a problemática) sob a forma de um estado da discussão, da questão, do saber, ele próprio encarnado por agentes e instituições, figuras notáveis, conceitos em -ismo etc. (BOURDIEU, 2001, p.137, grifo nosso) 
Vejamos então que, assim como Foucault pensava em uma episteme, Bourdieu pensa a ideia de campo como categoria fundamental de combate a uma compreensão da história do conhecimento metafísica ou isolada como história das ideias. Nessa direção, nossa pesquisa fez um esforço em reunir mais de um trabalho produzido na mesma época, com uma diversidade considerável de olhares sobre a literatura e de condições de suas produções. Nossa meta é pensar os "possíveis específicos" nos âmbitos da teoria, da estética e do valor literário, junto com o que seriam possíveis, nesse sentido, "inespecíficos" e relativos, em especial, ao campo do poder e da política. A ideia será identificar uma problemática comum a esses trabalhos que inclusive nos permitiria incluí-los dentro de uma geração.

O conceito de geração nos oferece a possibilidade de ler os estudos literários do nosso corpus principal como posicionamentos em relação a problemas compartilhados: “[...] todo produtor é irremediavelmente situado e datado enquanto participa da mesma problemática que o conjunto de seus contemporâneos (no sentido sociológico)" (BOURDIEU, 2005a, p.267). Ao mesmo tempo, auxilia-nos a romper com as ideias conservadoras de gênio e talento, que rondam os trabalhos e assinaturas com as quais aqui lidamos, e tomá-los como frutos de posicionamentos possíveis e facilitados pelos percursos de trajetórias compostas de contingências e sobredeterminações. Desta forma,

cada tomada de posição (temática, estilística etc.) defini-se (objetivamente e, por vezes, intencionalmente) com relação ao universo das tomadas de posição e com relação à problemática como espaços dos possíveis que aí se acham indicados ou sugeridos; recebe seu valor distintivo da relação negativa que a une às tomadas de posição coexistentes [...] (BOURDIEU, 2005a, p.263)

Assim, os agentes de um campo compartilham tanto das possibilidades quanto propriamente das leituras de revistas, frequentação de universidades, ocupação de cargos burocráticos, conquista de diplomas etc. Para esse sociólogo, não é o compartilhamento do mesmo momento cronológico que cria vínculo entre os trabalhos que analisaremos, mas o compartilhamento de expectativas, projeções, representações etc. semelhantes entre si por agentes em determinado momento e não de determinado momento.

É nesse sentido que Bourdieu (2001, p.139) afirma ser fundamental para o fim da ideologia do criador - segundo a qual as grandes descobertas, revoluções, transformações na história de um campo seriam frutos de indivíduos geniais - "admitir que o verdadeiro 'sujeito' das obras humanas mais bem-sucedidas não é outro senão o campo no qual, isto é, graças ao qual e contra o qual elas se realizam." Apesar dessa formulação fazer ressoar Foucault, autor de quem inclusive se aproxima ao dizer que "o inconsciente epistêmico é a história do campo" (BOURDIEU, 2001, p.120), não se trata, em nenhum dos dois casos, da afirmação de uma 
"morte do sujeito", ao contrário do que diria um leitor apressado em classificar. O esforço intelectual desses dois pensadores traz contribuições cruciais para a crítica de formas românticas de pensar categorias como autor, escritor, obra, leitor, etc. e, dessa forma, se há um sujeito que morre é o sujeito criador que carrega algum tipo de aura mágica que o permite criar grandes obras.

Em $O$ que é um autor (1992), transcrição de um debate do qual Foucault participa sobre a sua própria obra, ocorrido em 1969, Lucien Goldmann repõe a acusação de que, nos trabalhos de Foucault, Lévi-Strauss, Althusser, Derrida etc., haveria a negação do sujeito, na medida em que este seria transposto para a dimensão da estrutura ou da episteme, no caso. A ideia de função autor, contudo, tem como meta exatamente estabelecer a mediação entre o que é o sujeito empírico, a assinatura de um texto e a figuração de um autor no texto (narrador, eulírico, etc.). A ideia de "função" de uma autoria, ou seja, desta como "modo de existência, de circulação e de funcionamento de alguns discursos no interior de uma sociedade" (FOUCAULT, 1992, p.46), é então fundamental para a discussão não personalista dos textos, pois toca o sentido que os próprios textos, valores e discursos têm ou poderiam ter em uma comunidade e não as "pessoas autores".

A função autor teria como consequência imediata a ruptura com uma visão essencialista na qual a autoria deve ser uma unidade coerente, ainda que dividida em fases. Ela questiona uma historiografia que desde o século XIX submetia o "autor" aos princípios da “evolução, maturação ou da influência" (FOUCAULT, 1992, p.5) (de modo análogo às ciências biológicas) e às categorias a eles vinculadas de obra, pensamento ou estilo do autor que integram a compreensão romântica de que, associados ao espírito da época e suas características gerais, poder-se-ia elucidar e julgar de modo dedutivo um texto. Essa ruptura é crucial em nosso trabalho, na medida em que pressupomos não haver previsibilidade nos posicionamentos dos autores, porque eles não têm uma essência (esquerda, direita, rigoroso, criativo etc.) nem determinações diretas (elite, classe média baixa, universitários etc.), mas trajetórias que lhes colocaram possibilidades diferentes, vividas de formas diferentes, e que não podem ser descritas como qualidades inerentes.

A morte do sujeito ou do autor também não pode ser deduzida da formulação de Bourdieu de que o autor é o campo literário. Pelo contrário, trata-se da investigação da historicidade das escolhas por meio da reflexividade crítica dos estudos literários, a qual não pode ser conquistada com o estudo de um autor, no sentido convencional do termo, mas apenas a partir de um jogo de concorrência que une e contrapõe os posicionamentos de agentes em um campo num processo de produção de distinções que nunca para. Há, de fato, 
como indica em "É possível um ato desinteressado?" - transcrição de dois cursos publicados em 1988 -, a continuidade de uma concepção da sociologia como investigação de um nível profundo do que seria uma "lógica" de tais ou tais fenômenos sociais. Esse nível profundo não se dá, contudo, em uma relação de determinação direta de causa e efeito, mas passa pela tentativa de construir o que poderíamos chamar de sociologia do desejo ou da libido:

de fato, existem tantos tipos de libido quanto de campos: o trabalho de socialização da libido é, precisamente, o que transforma as pulsões em interesses específicos, interesses socialmente constituídos que apenas existem na relação com um espaço social no interior do qual certas coisas são importantes e outras são indiferentes, para os agentes socializados, constituídas de maneira a criar diferenças correspondentes às diferenças objetivas nesse espaço. (BOURDIEU, 1994, p.141-2)

Essa formulação é posterior à afirmação de uma ideia de homologia estrutural entre campos e campo e indivíduo, cuja construção máxima se deu em As regras da arte: gênese e estrutura do campo literário (2005). Essa ideia é marcada por uma abordagem, no limite, positivista, na qual incluiríamos a ideia de ciência das obras ou de ponto de vista total do campo $^{2}$. Ao contrário,em outra formulação posterior, de Meditações Pascalinas (2001), o sociólogo não menciona o termo homologia estrutural, mas apenas uma busca geral pelo não arbitrário dos gestos sociais, dentre os quais se integram as construções intelectuais. Nesse mesmo texto, inclusive, o sociólogo se atém em romper com uma filosofia da consciência, fundamentalmente cartesiana, que se preocuparia em distinguir, de forma precisa, o consciente do insconsciente, a má-fé da sinceridade, o premeditado e o espontâneo, o sensível e o inteligível etc. Pelo contrário, a ideia de interesse dos agentes é reformulada: "à redução ao cálculo consciente, oponho a relação de cumplicidade ontológica entre habitus e campo." (BOURDIEU, 2001, p.143). Os agentes de um campo "não são sujeitos diante de um objeto", ou de um problema "envolvidos em seus afazeres [...] presentes no por vir, no a fazer e no afazer (pragma, em grego), correlato imediato da prática (praxis) que não é posto como objeto do pensar, como possível visado em um projeto, mas inscrito no presente do jogo." (BOURDIEU, 2001, p.143)

Assim, trata-se aqui menos de se achar o motivo, a causa ou a origem de tais ou tais escolhas de um agente do que entender em que espécie de jogo simbólico em que suas escolhas estão inscritas como posicionamentos válidos. Tal é a illusio que constitui um campo, qual seja o interesse por participar e até mesmo dedicar a vida a esse jogo. A dimensão da escolha de um agente se dá sempre acompanhada de possibilidades exteriores a

\footnotetext{
${ }^{2}$ Aqui apontamos que, apesar de não podermos nos deter nisso, essa obra anterior talvez tenha caído em algo que o próprio Bourdieu (2001, p.147) sugere: “A prática tem uma lógica que não é da lógica e consequentemente, aplicar às lógicas práticas a lógica lógica, é arriscar destruir, através dos instrumentos que utilizamos para descrevê-la, a lógica que queremos descrever."
} 
uma discursividade específica e que podem ser desde uma vestimenta a uma variante linguística. Esses elementos, juntos, constituem um momento do habitus, conceito que teria uma função de "consciência transcendental", caso tivéssemos aqui uma filosofia do sujeito, e “é um corpo socializado, um corpo estruturado, um corpo que incorporou as estruturas imanentes de um mundo ou de um setor particular desse mundo, de um campo, e que estrutura tanto a percepção desse mundo como a ação nesse mundo." (BOURDIEU, 2005b, p.144, grifo nosso). Ele permite pensar simultaneamente o arbitrário da realização de toda ação como possibilidade e o não arbitrário do jogo no qual se dá o investimento da libido que a move. Nesse sentido, não se trata de "desresponsabilizar" ou apagar a responsabilidade dos agentes por suas escolhas por suas relações com o campo literário, mas de redimensioná-las dentro de uma illusio.

Como antecipa Bourdieu (2005b, p.137) falando de sua própria obra, em uma observação que também notamos em outro tempo e espaço, “o furor e o horror que o resultado do meu trabalho às vezes suscita talvez se explique em parte pelo fato de que esse olhar desencantado [...] também se dirige aos universos que são, por excelência, lugar de desinteresse [...] como é o mundo intelectual.”. Haveria então um fundamento histórico, dos conceitos, categorias, oposições etc., de um campo, e a tentativa de organização deste último contribui para que ele continue se transformando. Desta forma, se pensarmos dentro do que nos propõe, de modo geral, a obra de Bourdieu, veremos que a reflexão sobre o modo de produção de um discurso crítico ou literário é também uma reflexão sobre a própria produção crítica e literária. O estudo do campo literário, aparentemente "herege", pois fora das questões tidas como propriamente literárias, é, ao contrário, fortalecedor de sua autonomia, dado que esta depende da própria capacidade que um campo tem em questionar suas crenças e saberes por meio da reflexão de suas práticas. 


\subsection{Percurso de um caminho}

Passemos a um breve resumo da exposição de nossa pesquisa. Como mencionamos, na primeira parte desta pesquisa, vamos nos ater à historicidade do conceito de campo literário no período que estudamos; na segunda, investigaremos cinco estudos literários de fôlego pertencentes a esse momento de acordo com seus diferentes modos de compreensão da literatura; na terceira, veremos a maneira como estes modos de compreensão são acompanhados de distintos modos de valoração dos objetos literários. Ora, essa divisão se dá por uma necessidade de organizar a exposição de nossa pesquisa, mas, na prática, o como se compreende e o como se julga um texto literário não se separam, e um está pressuposto no outro. Ainda que muitos digam que a atividade de julgar um texto literário se vincula a priori a uma visão normativa da literatura, no próprio gesto de escolher um poema, um conto, um romance etc., está posto um juízo de valor.

Assim, no ponto 2.0, marcaremos algumas das transformações universitárias daquele momento, em especial do curso de Letras, a partir das trajetórias dos autores que assinam os trabalhos de nosso corpus, bem como do debate direto e indireto sobre essas mudanças. Com base nisso, arriscamos algumas especulações sobre elementos da historicidade do conceito de campo literário de Bourdieu quando deslocado da de seu emprego original.

No ponto 3.0, tentaremos ver nos livros que compõem nosso corpus principal diferenças que dizem respeito à compreensão do objeto literário. Quais são os pressupostos teóricos de suas leituras? Quais as outras disciplinas implicadas nessa compreensão? Qual ou quais as temporalidades históricas dessas compreensões? Quais são os problemas relativos a uma verdade filosófica, a uma realidade social etc. e em relação a quê se posicionam? Essas e outras questões são feitas nesse capítulo de investigação de definições do literário, depreendidas por meio das análises literárias ou de formulações explícitas.

Por fim, no ponto 4.0, estamos interessados nas tomadas de posições relativas ao valor literário. Nele, primeiro fazemos uma reflexão sobre os critérios de escolha na seleção de um objeto literário a partir de uma visão panorâmica das publicações de Roberto Schwarz, José Guilherme Merquior, Costa Lima, Silviano Santiago e Eduardo Portella entre 1960 e 1970. Em seguida, veremos como, no nosso corpus principal, o problema do valor literário pode ser pensado separadamente, sem poder se desvincular dos problemas teóricos e estéticos, ainda que sem relação de determinação direta com eles. 
Além da divisão por assuntos, há uma divisão do corpus com que trabalhamos. Nele, temos um principal e um secundário. O primeiro, nós citamos anteriormente e tratamos verticalmente nos pontos 3.0 e 4.2, sobre a compreensão e a valoração dos objetos literários construídos nesses trabalhos, respectivamente. O segundo, nós tratamos horizontalmente no ponto 4.1, sobre a escolha em falar de um texto literário do ponto de vista do valor literário. 


\subsection{Reflexões sobre as transformações universitárias de 1960 e 1970 e a ideia de campo literário}

\subsection{As lutas por autonomia e as transformações universitárias}

Os trabalhos sobre atividades do campo literário feitos a partir da sociologia de Bourdieu pouco têm se debruçado sobre a própria condição de existência do conceito quando deslocado para outra experiência histórica de produção, circulação e recepção da literatura, o que parece esvaziar, de certo modo, o emprego desse termo. Não se tratando aqui de um trabalho de sociologia, arriscamos uma apropriação heterodoxa do conceito de campo literário de modo a abdicar de uma pretensão, tal como o entende o sociólogo, de objetividade e a assumir uma postura especulativa e restrita, em seu ponto de partida, a um pequeno corpus de textos e problemas dos estudos literários da época. É a partir desse território que, junto com outros elementos não textuais, elucubramos sobre um funcionamento geral do campo literário. Apesar de restrito, ele nos permitiu observar diferenças em relação ao campo literário francês, tal como Bourdieu o descreveu. Se não foram suficientes para negar a autonomia relativa que garante a existência de um campo literário, não foram bastantes, no entanto, para fazer crer na centralidade da luta entre o amor puro ao conhecimento e à arte e o amor interessado nos bens temporais ${ }^{3}$.

O conceito de campo literário, tal como originalmente foi construído, pressupõe uma ideia de amor puro à arte, postura que tinha como lastro histórico uma nobreza e uma cultura de corte que afirmou, durante séculos, o valor dos jogos sem finalidades práticas. (cf. BOUDIEU, p.105-7). Este valor da gratuidade, presente também no trabalho intelectual, ainda que não seja garantia da leitura de Bourdieu, sem dúvida torna possível, entre outras coisas, a leitura que o sociólogo faz da história literária francesa. Ora, nos textos de nosso corpus, esse valor não opera de maneira a organizar as discussões, tendendo todos os agentes a buscar oferecer uma utilidade aos seus posicionamentos e propendendo a se distinguir a partir disso. No entanto, por mais que sejam íntimas as relações entre os campos do poder e da política com o literário, desde o século XIX, os homens letrados cultivaram, sem que isso fosse um objetivo, a subversão dos valores estritamente vinculados ao pragmatismo. No Brasil, talvez pelas atividades de escrita, leitura e publicação serem tão escassas e controladas pela coroa

\footnotetext{
${ }^{3}$ Sobre a problematização do conceito de campo literário do ponto de vista historiográfico, ver o debate Pierre Bourdieu e a história (2002).
} 
portuguesa ao longo da colônia ${ }^{4}$, a escrita como serviço a ser prestado ${ }^{5}$ tende a não ser motivo de desqualificação em si mesmo, ou seja, tende a não operar como distinção por parte de outros agentes, tal como descreve Bourdieu no surgimento do campo literário dos séculos XIX e XX francês.

Podemos dar como exemplo disso uma longa tradição de escritores brasileiros que foram canonizados sem que o fato de contribuírem regularmente para jornais fosse motivo para colocar suas obras sob desconfiança, ainda que, na hierarquia dos gêneros textuais, a crônica fosse tida como menor. Esse é o caso de Machado de Assis, Lima Barreto, Carlos Drummond, Clarice Lispector, Graciliano Ramos, Guimarães Rosa etc. Pelo contrário, essas produções não costumam ser vistas como voltadas para um espaço de linguagem necessariamente ligeira, mas que tende a ser ligeira (como se entenderia dentro da oposição entre amor puro à arte e arte voltada aos bens temporais), e parecem ajudar a canonização dos escritos "propriamente literários". Nesse sentido, a consagração do homem das Letras parece afirmar a herança forte de um modo instrumental de compreender a literatura, mas que compartilha com o campo francês uma hierarquia dos gêneros textuais que afirma a autonomia do ficcional.

Segundo aprendemos ao longo deste trabalho, qualquer tipo de "determinismo" que estabelece que um estudo literário seja de tal ou tal forma, a depender da trajetória de quem o assina, em especial de sua trajetória intelectual, é bastante equivocado e nega a arbitrariedade inerente a todo acontecimento histórico ${ }^{6}$. Contudo, sem sombra de dúvida, esses estudos têm relação com debates, oposições, noções e uma série de heranças de discursos de diferentes temporalidades sobre a literatura, a arte, a ficção etc. que a ideia de campo literário nos ajuda, antes de mais nada, a organizar e não a determinar.

\footnotetext{
${ }^{4}$ Aqui podemos nos referir à hipótese de Sérgio Buarque de Holanda, em Raízes do Brasil (1936) de que colonização espanhola, no que toca à fundação das universidades, investiu, construiu e viabilizou muito mais instituições de ensino superior do que a portuguesa (cf. HOLANDA, 1997, p.119-121). Essa disparidade foi objeto de estudo de muitas pesquisas que seguiram e a força de sua existência parece ser consenso entre historiadores.

${ }^{5}$ Como aposta João Adolfo Hansen: "O letrado colonial não é ainda uma figura social justificadora de um imaginário social associado a ela. Assim, não é ainda o 'autor' ou o 'escritor', no sentido iluminista e pósiluminista do termo; mas também não é mais 'escrivão' de uma corporação de ofício medieval. [...] Para esboçar a figura do letrado colonial é útil determinar o valor ou os valores da sua representação numa sociedade em que as pessoas e sua posição se definem por pertencerem a um grupo, a uma ordem ou um estamento, pela representação e como representação, mais que por seus atributos individuais. A identidade social do letrado colonial não se define especificamente no campo das letras, como campo literariamente autonomizado, mas no de outros serviços." (HANSEN, 2001, p.41)

${ }^{6}$ No período que nos interessa, por exemplo, a ação dos movimentos católicos e o Regime Militar "tiraram do eixo" o campo literário da época, tornando pouco previsível a movimentação de alguns intelectuais nesse momento. Em condições "normais", é possível que Roberto Schwarz não tivesse deixado a USP, nem Costa Lima fosse proibido de entrar na UFRJ. No caso do segundo, pode-se dizer que, como ele, outros críticos acabaram, por conta disso, passando a maior parte das suas vidas acadêmicas em instituições privadas e ficando, de certo modo, alijados dos debates sobre a universidade pública.
} 
Pois bem, a existência de um campo movido a uma racionalidade autônoma no Brasil, ou mesmo na França, é com frequência questionada. Contudo, mais importante do que correr atrás de uma espécie de "elo perdido" de um momento na história a partir do qual o campo literário passaria a existir, talvez seja investigar justamente a tensão entre um esforço de autonomia discursiva e outro de heteronomia, ou seja, como as lutas pela autonomização se deram. Para dar um exemplo do mesmo século analisado por Bourdieu, vejamos que, no caso do Brasil, o descrédito secular da Academia Brasileira de Letras (ABL) pode ser lido, desde o início, nesse registro. Em 1912, 15 anos após sua fundação, em 1897, o patrono da cadeira número 18, José Veríssimo, retira-se do seu posto alegando discordância inconciliável com o ingresso de Lauro Müller, ministro que nunca tinha publicado um livro ${ }^{7}$. Assim, Veríssimo tomava como posição a defesa da autonomia dos critérios de ingresso na $\mathrm{ABL}$ em relação ao campo da política. A autonomia, já no século XIX, veja-se, existe e é afirmada pela própria existência de uma Academia, no entanto, ela é mínima, pois o episódio toca o próprio caráter de Academia, qual seja, a reunião de doutos que possam ser assim reconhecidos por uma comunidade. Ainda que, de um total de 40 votos, ele tenha ingressado por apenas dois votos de diferença, indicando que havia uma pressão por valores que afirmavam a autonomia do campo literário, chama atenção o alto grau de heteronomia do caráter da discussão, o que talvez explique menos o resultado da votação do que o seu quase empate.

Ora, essa tensão entre autonomia e heteronomia também não se separa da reflexão sobre o convívio de temporalidades. Tirando o caráter anedótico do episódio, podemos pensar aquele tempo como luta simbólica entre um tempo em que as instituições públicas são só instrumentais, visto prevalecer o interesse privado de manter Lauro Müller, e um tempo em que elas passam a ser cobradas por sua finalidade pública, visto a opção por resistir de José Veríssimo e a votação ter sido decidida por dois votos. Assim como esse é um acontecimento político-institucional, cultural, antropológico, sociológico etc., poderíamos ter dado um exemplo da ordem da crítica literária.

Notemos, nessa mesma época, o compartilhamento no vocabulário de Romero e Veríssimo ao falar de algumas das condições que seu tempo colocava para a arte e para a literatura, respectivamente. No caso de Sílvio Romero, encontramos a afirmação de valores literários balizados fundamentalmente por traços marcados pela heteronomia do ficcional. $\mathrm{Na}$

\footnotetext{
${ }^{7}$ Segundo consta no site oficial da Academia Brasileira de Letras (2011), “em 1912, tendo a Academia aceitado a candidatura de Lauro Müller, ministro das Relações Exteriores, político e não homem de letras, e que foi eleito por 22 votos para a vaga do Barão do Rio Branco, derrotando o conde de Ramiz Galvão, Veríssimo sentiu desfazer-se a ilusão com que sonhara ao fundar-se uma instituição em que se recebessem exclusivamente expoentes da literatura e, desgostoso, afastou-se da Academia. Nunca mais manteve qualquer relação com a casa que ajudara a fundar.”
} 
defesa de uma poesia científica em seu primeiro livro de poemas Cantos do fim do século (1878), Romero afirma: “a arte não é agora uma caduquice [...] a arte funda-se hoje na intuição novíssima que a ciência desapaixonada e imparcial vai divulgando. Deve ser uma conseqüência e uma síntese de todos os princípios que até hoje têm agitado o século.” (ROMERO, 1960, p.1660). Segundo o autor, o seu livro de poemas seria o primeiro a recusar o romantismo brasileiro. Independentemente da veracidade ou não do seu juízo, há um desejo de marcar essa diferença, em nome de valores não literários, pois científicas e também políticas, uma vez que essa citação está num contexto em que Romero defende, de acordo com um valor nacionalista, que a literatura brasileira deve se atualizar quanto a isso.

No caso de José Veríssimo, ao encerrar o capítulo "Das condições da produção literária no Brasil”, de Aspectos da Literatura Brasileira (1977, p.48), ele afirma que "qualquer que seja, porém, o valor dessas condições, causas e incentivos da produção literária, aqui ou alhures, não pode esta ser valiosa sem que no escritor haja, além do talento, cultura que o fortifique e fecunde, ideias e sentimentos que o valorizem, e a ciência de exprimi-los.”. Aqui, como se vê, destaca-se uma ciência, ainda que particular, a da expressão, que poderíamos dizer que é a da própria linguagem literária e que está dentro de uma concepção romântica de criação artística como "expressão de um sentimento do espírito do sujeito". Isso que é, sem dúvida, uma afirmação de demanda por modos de compreensão específicos ao literário e, portanto, afirmação de autonomia do campo. Contudo, não escapa, como Silvio Romero, à preocupação com um projeto literário nacional, ainda que tenham visões distintas de como isso se dá teoricamente e na prática, por exemplo, no que toca a divergência entre ambos sobre a originalidade dos romances e contos de Machado de Assis. Nesse sentido, comparemos o posicionamento dos dois quanto a isso:

disse de Flaubert, com excelente senso crítico, Paul Bourget que ele havia, sem o saber, consorciado as duas tendências que dividiram a literatura francesa da primeira metade deste século: o gênio lírico de Victor Hugo e o talento de observação de Balzac. Da reunião destas duas forças saiu o livro admirável de Madame Bovary, que abriu uma era literária. Não se pode afirmar cousa idêntica de Machado de Assis: não se pôde dizer que ele haja reunido, em síntese superior, o gênio lírico de Alencar, de Álvares de Azevedo, de Varella, ao talento de observação de Martins Penna, de Manoel de Almeida, de Macedo; que tenha desse consórcio fecundo das duas principais correntes, que dividiram a literatura nacional durante a maior porção deste século, feito nascer a literatura de hoje, o espírito de nossos dias. E a prova mais evidente da negatividade de sua obra, é que não teve 
continuadores, não teve nem poderá ter discípulos; porque ele nada inventou, não produziu uma só ideia, que fosse um centro em torno do qual gravitassem as almas. (ROMERO, 1897, p.XIII-XIV)

desde, portanto, os anos 70, renunciando ao escasso romantismo que nele havia, criava-se Machado de Assis uma maneira nova, muito sua, muito particular e muito distinta e por igual estreme daquela escola e das novas modas literárias. Nessa maneira, particularmente em Brás Cubas e em Quincas Borba (1899), que se lhe seguiu e que a certos respeitos o continua, vislumbra-se mais do que percebe o remoto influxo dos humoristas ingleses, e antes dos seus processos formais que do fundo, que este é de raiz do autor. (VERÍSSIMO, 1998, p.407).

Vejamos que ambos os críticos compartilham o mesmo critério de julgamento de valor, ainda que cheguem em juízos opostos. Veríssimo é basicamente nacionalista e exige que os romances de Machado de Assis sejam autênticos em relação à literatura estrangeira. A diferença ocorre em relação ao como essa autenticidade deve se dar e não se ela deve se dar. ${ }^{8}$

Pois bem, neste capítulo, em que os estudos literários que analisaremos interessam do ponto de vista de suas condições de produção, podemos dizer que a reforma educacional dos militares no final de 1960 foi fundamental para a autonomia do campo literário, a começar pelo aumento do corpo de professores e pesquisadores universitários, agora posto alternativo aos antigos cargos públicos como aqueles ligados a secretarias, ministérios, embaixadas, etc. Ao que tudo indica, o aumento das possibilidades de fuga das relações entre intelectuais e poder acabou criando uma situação já bastante distinta daquela descrita por Sérgio Miceli em Intelectuais à brasileira (2001). Dos autores cujos trabalhos analisaremos, nesse período de 1960 e 1970, apenas Merquior e Portella ocuparam cargos públicos que não o de docente universitário. Apesar dos inícios de suas trajetórias serem muito diferentes, nesse ponto, elas se assemelham e isso talvez tenha relação com o fato de serem os únicos integrantes da $\mathrm{ABL}$ (Portella em 1981 e Merquior em 1983) dentre os críticos que assinam os trabalhos do nosso corpus. Merquior desde cedo opta pela carreira diplomática como lugar no qual se estabelece profissionalmente, enquanto Portella escolhe o âmbito executivo da política, entrando aos 28 anos, em 1960, na Secretaria Geral de Educação e Cultura do Estado da Guanabara. Amigo de

\footnotetext{
${ }^{8}$ No caso de Veríssimo, a passagem que se segue estabelece melhor seu posicionamento quanto a isso "não fazendo senão repetir servilmente o estrangeiro, sem nenhuma originalidade de pensamento e de forma, sem ideias próprias, com imensas lacunas de erudição, e não menores deficiências da instrução comum hoje aos homens de mediana cultura nos países que pretendemos imitar e seguir, nós não podemos competir com o que eles de lá recebem em primeira mão, oferecendo-lhes um produto similar em segunda." (VERÍSSIMO, 1978, p.159)
} 
Tancredo Neves, o crítico chega a se engajar no Gabinete Civil da Presidência da República e em secretarias estaduais cariocas, em geral nas áreas da educação e cultura, em diferentes governos. A carreira acadêmica ficou, assim, para a maturidade e apenas em 1970, aos 38 anos, defende o doutorado na Universidade Federal do Rio de Janeiro (UFRJ), onde passa a dar aulas no curso de Letras, além de ocupar cargos administrativos como o de Diretor da Faculdade de Filosofia (cf. ACADEMIA BRASILEIRA DE LETRAS, 2012).

Evidentemente que o envolvimento de Merquior e Portella com a ditadura militar era de níveis e de naturezas diferentes, tendo o primeiro, como veremos, se colocado abertamente contra a reforma educacional dos militares, ainda que de modo conservador, como veremos, enquanto o segundo se torna ministro da educação em 1979. De todo modo, outro indício de que em 1960 e 1970 as relações com o campo da política mudavam é que dos cinco críticos aqui estudados, dois já puderam fazer suas primeiras graduações em faculdades que não eram eminentemente aplicáveis. Três deles cursaram Direito e o Licenciamento em Filosofia, Costa Lima, Portella e Merquior, enquanto Silviano Santiago fez o bacharelado em Letras, na Universidade Federal de Minas Gerais (UFMG) e Roberto Schwarz fez Ciências Sociais na Faculdade de Filosofia Ciências e Letras (FFCL).

Paralelamente, contudo, a essa possibilidade de autonomia em relação aos postos de trabalho, a tortura e a prisão estavam no horizonte de qualquer tipo de produção artística e intelectual, condição que parece suspender a ideia de autonomia de antemão, pois ela pressupõe o que Bourdieu chamará de contenção da violência, não só discursiva, mas também de um campo sobre o outro. Esse aparente paradoxo se deu de modo complexo e é necessário apontar que esse aumento das condições materiais de independência em relação aos campos da política e do poder foi acompanhado de poucas condições simbólicas para tanto. Afinal, os novos postos de trabalho criados integravam um projeto de perda de autonomia política das universidades públicas, a começar pela imposição de uma reforma educacional, passando pela restrição política do corpo docente, como se deu mais fortemente na UFRJ e na Universidade Nacional de Brasília (UNB), onde o governo militar tinha facilidade de intervenção mais direta 9 .

\footnotetext{
${ }^{9}$ Com isso não queremos dizer, de modo algum, que em alguma universidade pública a atuação da ditadura tenha sido amena e, como aponta a publicação da Associação dos Docentes Universidade de São Paulo (Adusp) (2004), uma série de aposentadorias foram impostas, particularmente à FFCL da USP, pelo AI5, em 1969, por exemplo a de Bento Brado Junior, Caio Prado Júnior, Emília Viotti da Costa, Fernando Henrique Cardoso, Jean Claude Bernadet, José Arthur Giannotti, Mário Schenberg, Octávio Ianni, Paula Beiguelman etc. Como comenta a própria publicação da Adusp (2004, p.69-70), o papel de Antonio Candido se destaca no que chama de terceira fase, de 1970 em diante, intercedendo à favor de outros professores ameaçados: "nos casos que afetaram diretamente o professor Antonio Candido, que é certamente uma das pessoas de maior prestígio intelectual e pessoal dentro da USP, sua interferência direta e incansável logrou transpor a barreira do chamado "terceiro estágio'. Em muitos outros casos intercessão semelhante não se deu, ou não surtiu efeito.”
} 
A ampliação do acesso à universidade também era estratégica porque a esquerda não podia se opor diretamente, ao mesmo tempo que passaria a ter um corpo muito maior e mais heterogêneo de estudantes para ganhar para si. Vejamos as transformações numéricas do corpo discente. Segundo nos conta Hallewell (2005, p.686):

os 44.100 estudantes universitários de 1950 subiram para 93.206 em 1960, [...] e mais de um milhão em 1975. Na década de 1960, teve início uma expansão correspondente no nível de pós-graduação, passando o número de mestrandos de 2.489, em 1960, para 16.002, quinze anos mais tarde. Finalmente, ocorreu o crescimento dos programas de doutoramento: de 500 doutorandos em 1970 para 1258, em 1975.

A ampliação abrupta do acesso à universidade e também pôs imediatamente sob suspeita seus critérios, bem como as competências necessárias para lá permanecer e prosseguir nas funções esperadas. Ela ainda implicou uma maior distância entre professores e alunos no que diz respeito tanto à origem de classe como aos capitais escolares esperados pelos primeiros e acumulados pelos segundos, e serão vários os posicionamentos em relação a isso. De todo modo, a formação da graduação e da pós-graduação em Letras entrava num momento de aprofundamento ainda maior da falta de capital simbólico e material. A ampliação da rede universitária acabou por provocar um excesso de oferta de mão de obra na área e uma consequente desvalorização material e simbólica de seus títulos universitários. No fim de 1970, a impressão que se tem é de que o curso de Letras forma profissionais imediatamente identificados como "vítimas" de um sistema educacional ditatorial e formador de especialistas que, enquanto tais, eram vistos como despreparados diante das exigências colocadas pela formação interdisciplinar anterior.

A expansão da graduação e pós-graduação implicou também um crescimento relevante no setor livreiro. Como fizeram com outros setores da economia, os militares privilegiaram a vinda de empresas estrangeiras para atender nossa demanda interna. Motivada pelo aumento abrupto do número de leitores, essa internacionalização fez aumentar consideravelmente a produção da mercadoria livro e simbolicamente isso implicou que também a "façanha" da publicação passasse a perder consideravelmente o prestígio, o que parece ter criado a necessidade de afirmação de valores mais rígidos na atribuição da qualidade destes.

Como se vê, neste fim de anos 1960 e início dos anos 1970, há, portanto, uma transformação profunda do mercado de bens simbólicos e das condições sociais de possibilidade dos estudos literários que engendraram mudanças cruciais na organização do trabalho intelectual de modo geral. Dentre elas, devemos apontar também a queda de um ideal 
universitário humboldtiano. Segundo a análise de Franklin L. e Silva (1999, p.18) sobre a Faculdade de Filosofia, Ciências e Letras da Universidade de São Paulo (FFCL-USP):

aquilo que, para os liberais fundadores deveria ser a finalidade, isto é, a capacidade de refletir criticamente sobre a cultura e a política, transformavase agora num verniz apressado, que o aluno receberia antes de passar às coisas realmente importantes. Para atingir a finalidade de colocar a universidade como formadora de recursos humanos para o desenvolvimento nacional seria preciso de um lado baratear a cultura propriamente universitária e, de outro, destituir a formação crítica de sua função central.

Sérgio Buarque de Holanda, Roger Bastide, Antonio Candido, Álvaro Lins, Augusto Meyer, Barreto Filho, Afrânio Coutinho etc. são exemplos de que a crítica de arte estava no campo de possibilidades dos intelectuais da área de humanas de modo geral, e ainda nas décadas 1960 e 1970 também vimos surgir críticos importantes com múltiplas competências para falar de diferentes artes. A presença textual de conhecimentos filosóficos, sociológicos, psicanalíticos, etc. nos textos de análise e comentários de literatura acabam servindo como elementos que identificam o próprio texto como de crítica literária e sua assinatura como de crítico. Entre a reforma educacional dos militares e seus primeiros frutos acadêmicos, que surgem em meados de 1970, parecia estar quase extinta, para os que ingressavam no campo literário naquele momento, a possibilidade de uma trajetória intelectual viabilizada pelo modelo de universidade que agora ruía.

O trabalho de maior fôlego sobre as relações entre crítica literária e instituições universitárias é a tese de doutorado de Rachel Esteves de Lima intitulada $A$ crítica literária na universidade brasileira $^{10}$. Para a autora, que se detém na Universidade de São Paulo (USP), na Universidade de Campinas (Unicamp), na Universidade Federal do Rio de Janeiro (UFRJ), na Pontifícia Universidade Católica do Rio de Janeiro (PUC-Rio) e na Universidade Federal de Minas Gerais (UFMG), "nenhuma das faculdades que têm sido abordadas passou incólume à racionalidade científica que dominou a área de Letras nas décadas de $1950 \mathrm{a}$ 1970.” (LIMA, 1997, p.296) Recorrendo então a passagens de No hospital das letras, polêmicas (1963), de Afrânio Coutinho, e O método crítico de Sílvio Romero (1945), de Antonio Candido ${ }^{11}$, para provar essa tendência à objetividade científica, a pesquisadora inova

\footnotetext{
${ }^{10}$ A tese foi defendida no ano de 1997 na Universidade Federal de Minas Gerais (UFMG). O seu trabalho tem por corpus as dissertações e teses defendidas no período de 1975 a 1990 nas áreas de Literatura Brasileira, Literatura Comparada e Teoria Literária e tenta identificar e relacionar, desde as fundações das Faculdades de Filosofia no início do século XX, as diferentes organizações institucionais dos cursos de Letras; seus diversos currículos de graduação e pós-graduação e, principalmente, traços gerais da produção de pesquisa dessas universidades nessa área.

${ }^{11}$ Retomemos uma das passagens que Rachel utiliza para demonstrar essa tendência no caso do livro de Antonio
} 
ao romper com o que aparentemente era uma oposição radical entre esses autores, vendo-os como protagonistas fundamentais na reestruturação do curso de Letras.

Ambos fariam parte de uma geração que construiu a passagem da crítica do jornal para a universidade, fenômeno que traz consigo um processo de especialização defendido, especialmente, por Afrânio Coutinho, sendo sintomático que enquanto na UFRJ o curso de Letras se desvinculava da área de Ciências Humanas e se associava ao Centro de Letras e Artes; na USP, ao contrário, Antonio Candido fazia resistência e defendia a permanência do curso de Letras como parte da Faculdade de Filosofia. Além disso, Afrânio Coutinho também foi o grande defensor da implementação da disciplina de Teoria Literária, inicialmente lecionada por ele, a partir de 1950, na Faculdade de Filosofia, Ciências e Letras do Instituto Lafayete.

De todo modo, não há dúvida de que as mudanças curriculares impostas aos cursos de Letras nessa reforma educacional implicaram outra dimensão da sua justificação simbólica. Se em 1940 ou 1950 os grandes acontecimentos literários e críticos poderiam passar ao largo de um curso que, pelos depoimentos, parecia quase que consensualmente não recomendável para quem queria estudar literatura, com o sucesso da implementação da Reforma Universitária de 1968, passamos a ter a exigência de competências simbólicas adquiridas apenas nos cursos de Letras, como o contato com as diferentes teorias literárias e da linguagem.

Candido, caso em que isso está menos evidente: "hoje só podemos conceber como científica a crítica que se esforça por adotar um método literário científico, um método específico, baseado nos seus recursos internos. Estabelecimento de fontes, de textos, de influências; pesquisa de obras auxiliares, análise interna e externa, estudo da repercussão; análise das constantes formais, das analogias, do ritmo da criação: esta seria a crítica científica, a ciência da literatura." (CANDIDO, 1988, p. 110) 


\subsection{A atribuição do adjetivo nacional ao termo campo literário}

Passemos então para alguns problemas na atribuição do adjetivobrasileiro ao termo campo literário. Ora, não é possível delimitar até onde vai um campo nacionalmente e até onde vai outro, pois eles se constituem, historicamente, também em relação uns aos outros. Isso não quer dizer, contudo, que o problema da nacionalidade não exista material e simbolicamente. Como o próprio Bourdieu indica, não é possível discutir instituições escolares, por exemplo, sem que isso passe pela construção de um projeto de nação a serviço de que estão ${ }^{12}$. Ao mesmo tempo que as instituições em geral e as universitárias em particular também dão condições para a especificidade de um debate local, elas instituem, de diferentes formas e no modo como se legitimam, o constante intercâmbio com a produção intelectual feita em outros países, ou seja, contribuem para a possibilidade de uma produção conjunta e de um compartilhamento de saberes e concepções assim como já o são as próprias ideias de universidade e nação.

Nesse sentido, tomamos a universidade como instituição estratégica para pensar também a respeito da própria ideia de campo como "nacional". O termo significa aqui dois problemas, um interno e outro externo, pois assim sua definição como unidade implica. $\mathrm{O}$ primeiro coloca essa exigência de unidade que demandaria, na verdade, uma pluralidade e um corpus de pesquisa maior, bem como informações sobre a reforma universitária em universidades fora do sudeste. O segundo, o problema externo do termo "nação", implica que precisaríamos comparar as instituições brasileiras universitárias com a de outros países. $\mathrm{Ou}$ seja, em ambos os casos, o adjetivo demandaria uma pesquisa sociológica. Aqui, restringindo nossas especulações ao nosso corpus, segue o que pudemos perceber a partir da movimentação dos agentes que assinam os textos que o compõem.

As cinco trajetórias que nos interessam, quais sejam, as de Roberto Schwarz, Merquior, Costa Lima, Silviano Santiago e Eduardo Portella são marcadas pelo estudo e/ou docência na Europa ou nos Estados Unido. Nisso há muitas especificidades nacionais, a começar pelo fato de as universidades brasileiras serem as mais recentes da América e o que isso pode ter colocado para a produção de pesquisa e para reconhecimento social das atividades intelectuais não imediatamente aplicáveis. Essa especificidade histórica, contudo,

\footnotetext{
${ }^{12}$ Ao falar dos esquemas classificatórios de uma comunidade o sociólogo diz: "o senso comum é em grande parte nacional porque quase todos os grandes princípios de divisão têm sido até agora inculcados ou reforçados pelas instituições escolares, cuja missão máxima consiste em construir a nação como população dotada das mesmas 'categorias'; logo do mesmo senso comum.” (BOURDIEU, 2001, p.119)
} 
está junto com outra, a de que, tanto no século XIX como no XX, o que se entendeu por universidade surgiua partir de teorias e experiências que se deram na Alemanha, na França, na Inglaterra e nos Estados Unidos. Isso fez com que compartilhássemos mais (ou menos) de tempos de instituições internacionais e não de um tipo de essência impresso nos trabalhos a eles vinculados. De todo modo, se os críticos com que trabalhamos aqui se vinculam a universidades brasileiras, cada uma delas terá sua especificidade e sua "internacionalidade", vamos dizer assim, podendo facilitar o acesso a cursos, frequentação de bibliotecas, conhecimento de pesquisas recentes etc. de universidades estrangeiras.

Vejamos, nesse sentido, que também o incentivo à pesquisa fora do país passava por um momento de transição. Isso porque ela tanto se dá por meio de institutos tradicionais e convites pessoais como, de modo já profissionalizado, por meio da aquisição de um título universitário em uma universidade estrangeira. No caso do primeiro, aqui apareceram a Bolsa do Instituto de Cultura Hispânica, em Recife, que Costa Lima e Portella conseguiram no mesmo período; a bolsa da Maison France, dada aos melhores alunos de seu curso, no Rio de Janeiro, e que Silviano Santiago ganhou para fazer o doutorado sobre André Gide na França, sob orientação de Pierre Moreau na Universidade de Paris; e, por fim, o convite de WolfDieter Stempel a Costa Lima para passar três meses em Konstanz, na Alemanha, de fim de 1974 a começo de 1975, e conhecer a estética da recepção.

Já no caso da pesquisa fora do país por meio da aquisição de título, ela foi uma experiência pela qual passaram todos os críticos aqui estudados, com exceção de Costa Lima $^{13}$. Além de Silviano Santiago, Roberto Schwarz e Merquior titularam-se em universidades francesas. Schwarz fez mestrado em Yale, cujos ensaios são posteriormente publicados em A sereia e o desconfiado (1965) e o doutorado em estudos latino-americanos na Sorbonne (Universidade de Paris III) com a tese "Ao vencedor as batatas"; Merquior, em 1965, publica a Razão do Poema e vai para França, onde permanece de 1966 a 1970 como aluno titular do Seminário de Antropologia do Collège de France, cujos trabalhos são

\footnotetext{
${ }^{13}$ Notemos que Schwarz é o único crítico cuja ida para o exterior para fazer o mestrado é fruto da perseguição política: "Em começo de 1969, à vista da prisão e tortura de pessoas próximas, julguei prudente viajar. Andei bem, pois pouco depois o meu apartamento foi visitado pela polícia. Chegando à França, contei com a solidariedade que colegas e governo deste país manifestavam aos refugiados - o que me valeu durante um ano o estipêndio destinado a 'personalidades convidadas'. Assim, pude retomar a vida intelectual em boas condições" (SCHWARZ, 1990). Já Costa Lima é o único crítico que é impedido de estudar no exterior por perseguição política, como relata em Luiz Costa Lima: uma obra em questão (2010), do período do golpe até 1974 não conseguia sair do Brasil para estudar ou lecionar. Ao falar de pessoas importantes para ele nesse período ele conta: "prefiro terminar essa nomeação com dois nomes que serão determinantes para que conseguisse ultrapassar ao menos um pouco o isolamento em que minha língua materna me punha e em virtude de as autoridades militares não me darem direito a um passaporte. A primeira é Wolf Dieter Stempel. Graças a ele, aliado à sorte de ter um parente que conseguiria furar o bloqueio de não poder sair do país, pude conhecer in loco os principais feitores da estética da recepção." (p. 267)
} 
publicados no livro O estruturalismo de Lévi-Strauss (1975); ainda na França ele se torna Doutor com Verso Universo em Drummond (1975), sob orientação de Raymond Cantel, diretor do Instituto de Estudos Portugueses e Brasileiros da Universidade de Paris, e é aprovado pela Sorbonne. (cf. PEREIRA, 2010)

Notemos que neste momento Merquior se dedica a um esforço semelhante ao de Costa Lima, porque ambos investigam a obra de Lévi-Strauss, interessados em sua reflexão sobre a arte. Contudo, vejamos a diferença de condições simbólicas de produção de pesquisa e construção da legitimidade da leitura de cada um. Merquior $(1975$, p.10) constrói seu trabalho como fruto da frequentação de quatro anos de curso de pós-graduação no Collège de France, "regido pelos mais severos padrões intelectuais", legitimado pelo que seria a autoridade máxima sobre seu trabalho: "tive então o contentamento de ver esse trabalho recebido pelo fundador da antropologia estrutural de forma excepcionalmente lisonjeira", ou seja, por LéviStrauss. Costa Lima, ao contrário, continuava um debate feito em um grupo de estudos informal com orientandos em uma faculdade particular, católica e, não esqueçamos, numa época de ditadura, o que o obrigou a defender sua tese de doutorado na $\mathrm{USP}^{14}$ e reduziu a sua comunicação com Lévi-Strauss a cartas que, segundo o autor, eram simpáticas ao seu trabalho, mas se perderam ${ }^{15}$. Aliás, no caso desta última diferença, damos um exemplo de que, apesar da formação fora do país ter sido comum a todos, ela se deu de formas muito diferentes e não necessariamente pressupondo o deslocamento físico dos agentes.

Os Estados Unidos parecem ter sido, quantitativamente, o país mais presente na formação desses críticos nesse momento. No caso das titulações, Roberto Schwarz, sob os conselhos de Antonio Candido, consegue uma bolsa de pesquisa de um ano e meio para fazer mestrado em Teoria Literária, sob a orientação de René Welleck, na Universidade de Yale. Silviano Santiago também tem uma passagem fundamental pelos Estados Unidos e Europa, onde fez o doutorado na França, enquanto lecionou na University of New Mexico, em Albuquerque; na Rutgers University, em New Jersey; na Toronto University, em Toronto, única universidade fora dos EUA; e na State University of New York at Bufallo, em Bufallo (cf. SANTIAGO, 2008, p.175-7).

\footnotetext{
${ }^{14}$ A defesa de Costa Lima foi formada por Marilena Chaú, Leyla Perrone-Moisés e José Carlos Garbuglio e o autor nos conta em comunicação informal, no Rio de Janeiro, em 2010, que foi duramente criticada, sendo tida por inacabada e hermética. O depoimento do autor coaduna com aquele de seu orientador nesse período de sua defesa. Na mesma carta que já citamos anteriormente, Antonio Candido diz que "apesar de excelente rapaz", Costa Lima era "extremamente confuso e pedantesco, a ponto de tornar por vezes ininteligíveis os seus escritos e falas." (CANDIDO apud. AGUIAR, VASCONCELOS, p.339).

15 Informação fornecida por Luiz Costa Lima em comunicação informal no Rio de Janeiro, em 2010.
} 
Assim, além de o adjetivo brasileiro, no limite, ser impossível de ser atribuído de modo absoluto ao termo campo literário, dado o papel das instituições universitárias de outros países na constituição do corpo das universidades brasileiras, caberia lembrar questões que tocam o colonialismo cultural interno, colocado por Marta Campos em Colonialismo Cultural interno: o caso nordeste (1986), e que são fundamentais para não tratarmos como unidade pacificada relações pautadas em coerções materiais e simbólicas. O Brasil do último quarto do século XX passa a abrigar dois grandes centros culturais, Rio de Janeiro e São Paulo, e o fato de serem centros urbanos foi fundamental para se tornarem também o centro de instituições não oficiais, tais como os círculos de frequentação que reuniam intelectuais, artistas, críticos, escritores, músicos, etc.

Até a geração de 1960, por exemplo, Recife marca um lugar do campo intelectual do Brasil que, desde o XIX, no que diz respeito à história intelectual, nega a prática da mera reprodução do que é feito nos outros centros brasileiros e mundiais. Não se trata de criar um grande balaio em que caibam os mais diversos intelectuais que nasceram nessa cidade, mas de verificar que os agentes que tiveram o início de sua trajetória intelectual nesse lugar do campo foram tidos como importantes intelectuais brasileiros do século XX: Paulo Freire, João Cabral de Melo Neto, Gilberto Freire, Sebastião Uchoa Leite, Costa Lima, Eduardo Portella etc. Evidentemente, a Universidade de Pernambuco, em especial a Faculdade de Direito e o Instituto Joaquim Nabuco, fundado por Gilberto Freire, cumpriram papel importante na trajetória desses autores, assim como um "clima" cosmopolita particular ao XIX de Silvio Romero ou de Tobias Barreto

No período que investigamos, paulatinamente se tornou mais difícil intelectuais e artistas fazerem seu trabalho circular no resto do país estando fora do Rio de Janeiro ou de São Paulo, o que parece ter gerado uma migração de intelectuais para o sudeste e prejudicado o fortalecimento de pólos culturais independentes desses centros ${ }^{16}$. Nesse sentido, notemos que dos cinco críticos que tratamos aqui, três deles saem das capitais onde nasceram e/ou tiveram sua primeira formação acadêmica, e vão em direção ao Rio de Janeiro. No caso do

\footnotetext{
${ }^{16}$ Vejamos o tipo de consequência simbólica que isso teve, junto com todas as outras disparidades econômicas, numa declaração exemplar de Roberto Schwarz: "para um exemplo mais complexo desta disparidade entre prática reformista e seus resultados culturais, veja-se o Movimento de Cultura Popular em Pernambuco [...]. O programa era de inspiração cristã e reformista, e a sua teoria centrava na 'promoção do homem'. Entretanto, em seus efeitos sobre a cultura e suas formas estabelecidas, a profundidade do M.C.P. era maior. [...] Durante este breve período, em que polícia e justiça não estiveram simplesmente a serviço da propriedade (notavelmente em Pernambuco), as questões de uma cultura verdadeiramente democrática brotaram por todo canto, na mais alegre incompatibilidade com as formas e o prestígio da cultura burguesa [...] O país estava irreconhecivelmente inteligente." (grifo nosso) (SCHWARZ, 1992, p.69) Os termos grifados deixam claro que, apesar das positividades que apresentavam às experiências artísticas e políticas, as expectativas por parte dos intelectuais do sudeste em relação aos do nordeste eram bastante baixas.
} 
crítico mineiro, Silviano Santiago, único que não nasceu na capital do seu Estado, mas sim em Formiga, o primeiro passo foi ir para Belo Horizonte, onde cursou Letras-neolatinas na Universidade Federal de Minas Gerais (UFMG). Já Eduardo Portella, nascido em Salvador, foi para Feira de Santana cursar o primário e depois para Recife, em Pernambuco, que naquela época funcionava como pólo cultural e intelectual do Nordeste. Costa Lima, por sua vez, nasceu em São Luis, no Maranhão, e foi levado ainda muito pequeno para Recife, para que seu pai pudesse se arriscar na carreira política. Caberia destacar também que há uma coincidência entre esse deslocamento e uma origem de classe com menor capital econômico e/ou cultural, como é o caso de Silviano Santiago, Costa Lima e Portella se comparados aos críticos do eixo Rio - São Paulo, Merquior e Roberto Schwarz ${ }^{17}$.

A opção parece ter sido o caminho "natural" por serem não só grandes centros universitários, mas também centros editoriais. Segundo nos conta Laurence Hallewell (2005, p.610), “em 1957 eram responsáveis por 56, 5\% dos títulos e 82\% do valor produzido. Em 1973, esses números haviam subido, segundo o Snel, para 96,6\% e 97,9\% dos exemplares." Além do mercado consumidor estar concentrado nesse eixo, o Norte e o Nordeste do país tiveram a sua circulação de livros muito prejudicada pela inflação, que pedia investimentos a

\footnotetext{
${ }^{17}$ Todos os autores empíricos têm origem na classe média ou na elite, filhos de profissionais liberais, e viram, no período em questão, os estudos literários se manterem como possibilidade de distinção, bem como de ascensão ou manutenção nessas classes. Essas origens variam entre frações dessas classes, principalmente quando o assunto é o reconhecimento da vida acadêmica, ou seja, quando a herança é simbólica. Essa diferença é relevante porque, sem esta outra herança o próprio capital material da família não se converte em herança, como no caso de Costa Lima.

Silviano Santiago é filho de um dentista e farmacêutico, a mãe falecera e deixara o pai viúvo com sete filhos. Muito cedo a família muda para Belo Horizonte para "baratear" o custo do estudo dos filhos, por exemplo, o caso de um irmão de Silviano que chegou a estudar em colégios como o Lafayette, o mesmo em que estudara Merquior, no Rio de Janeiro. Apesar de oriundo da classe média, a fração de classe a que pertence é a pequena burguesia, e a quantidade de irmãos provavelmente apertava financeiramente a família. Também Eduardo Portella é filho de comerciante, o espanhol Enrique Portella, que chega pequeno ao Brasil, e da brasileira Maria Diva Mattos Portella, professora de português (PORTELLA, 2008, p.14). Ao que tudo indica, Portella também ascendeu consideravelmente, ainda mais se pensarmos que chegou a ser ministro. Pois bem, Costa Lima, ao que tudo indica, é filho de um proprietário rural, engenheiro que vai arriscar a carreira política no Maranhão, enquanto sua mãe parecia se dedicar às tarefas de casa, ao piano, aos romances, segundo nos contou em comunicação informal no Rio de Janeiro, em 2010. Em Recife, Costa Lima diz que sua família morava perto, nos arredores da praça Casa Forte, "uma espécie de feudo dos Costa Lima" (COSTA LIMA in BASTOS, 2010, p.317), o que também indica poder econômico. A opção pelas Letras, contudo, parece ter impedido Costa Lima de usufruir parcialmente da herança, dado o fato de ter sempre tido postos de trabalhos fixos. Esse problema de reconhecimento das atividades intelectuais na área de humanas não o teve o crítico Roberto Schwarz, filho de Käthe e Johann Schwarz, intelectuais austríacos judeus que fugiram da invasão alemã em 1939 e que, ao que tudo indica, tinham boas condições financeiras. Por fim, filho do advogado Danilo Merquior e de Maria Alves Merquior, José Guilherme completa seus primeiros estudos no Colégio Lafayete, conhecido pelo rigor e pela disciplina, bem como por ser procurado pelas famílias de classe média alta e pela elite do Rio de Janeiro daquele fim dos anos 1950. Segundo a sua pequena biografia nos conta, o crítico parece ter tido, além de uma juventude abastada (dada as viagens que, nessa época, fazia à Europa), pais que também valorizavam a carreira acadêmica. Como Pereira nos conta, "um dos primeiros presentes que ganhou do pai foi a abertura de uma conta sem limite na livraria Leonardo da Vinci, de D. Vanna Piracini, no centro do Rio." (PEREIRA, 2010)
} 
curto prazo; pela distribuição, lenta e cara para essas regiões; e pela lentidão de sua produção de títulos.

Portella, Silviano Santiago e Costa Lima, todos escolheram o Rio de Janeiro para morar. Essa cidade parece ter apresentado uma melhor opção para esses críticos não à toa. Ela oferecia tanto uma oferta maior em termos de vagas para docentes como parecia abrigar um ambiente intelectual e artístico mais presente. Um exemplo disso seria que, segundo Laurence Hallewell (2005, p.610), no que toca os livros de ficção em geral: "as editoras do Rio produziam, entre 1973 e 1976, 79\% dos títulos de literatura e 66\% dos exemplares, enquanto cabia a São Paulo 18\% dos títulos e 34\% do total de exemplares." O investimento em livros de ficção por parte de editoras pressupõe não só um risco maior, pois não são livros técnicos de saída garantida, como um público de leitores que estimula esse risco. Ao que tudo indica, a antiga capital do Império manteve como ponto de honra o lugar de pólo cultural do país e implementou algumas políticas locais para tanto ${ }^{18}$.

Pois bem, notemos que entre São Paulo e Rio de Janeiro também há muitas diferenças. No período que aqui tratamos, conforme observa Laurence Hallewell (2005) e Rachel Esteves de Lima (1998), a perseguição política a universitários parece ter sido mais intensa na cidade carioca. Segundo o primeiro nos conta, da perspectiva da produção de livros, por exemplo:

de modo geral, o Rio de Janeiro sofreu mais do que São Paulo. Os primeiros tempos da Revolução, isso se deveu principalmente ao zelo do então governador da Guanabara [...]. Ênio Silveira, juntamente com muitos outros eminentes cariocas de posições suspeitas (Ferreira Gullar, Dias Gomes, Moacyr Félix, Álvaro Lins, Édison Carneiro, Carlos Ribeiro, Alex Viany, José Leite Lopes e Oscar Niemeyer), tiveram suas próprias casa invadidas em busca de livros para confiscar. (HALLEWELL, 2005, p.576)

Sem sombra de dúvida, a Universidade de São Paulo (USP) está, em relação a isso, em posição de vantagem do ponto de vista político e material. No caso do primeiro, apesar dos inúmeros professores aposentados na Faculdade de Filosofia, Ciências e Letras (FFCL), na área de Letras, Antonio Candido conseguiu abrigar intelectuais que haviam sido impedidos de prosseguir seus trabalhos em outras universidades ou mesmo na USP por perseguição política, tais como Costa Lima, João Alexandre Barbosa ou João Luiz Lafetá. Como nos conta Irene

\footnotetext{
${ }^{18}$ Segundo Portella (2011) conta sobre sua passagem como Secretário Geral de Educação e Cultura do Estado da Guanabara em 1960, houve "um esforço primeiro no sentido de manter o Rio de Janeiro como capital cultural, já que estava havendo a modificação para Brasília e nós entendíamos que o Rio de Janeiro tinha que continuar sendo um grande pólo cultural, como era o caso de nova York, sem que ela seja a capital dos Estados Unidos. De maneira que este esforço na secretaria com Celso Cunha, com Vicente Câmara, foi um esforço no sentido de preservar um conjunto de valores e tomar algumas iniciativas que fortalecessem essa condição de capital cultural do Estado."
} 
Cardoso, em A universidade da comunhão paulista (1982), a USP é fundada pelas elites ilustradas paulistanas que assim davam uma resposta à derrota que haviam sofrido na guerra civil de 1932. O objetivo da sua fundação, em especial o de sua Faculdade de Filosofia, era formar uma elite dirigente capaz de dar conta da nova racionalidade que acreditavam exigir uma nova administração pública.

Sendo desde o início do século XX o estado de São Paulo aquele com a maior receita do país, a USP teve, perto de outras universidades, um investimento financeiro consideravelmente maior. Assim, de um lado, temos ela que, com o financiamento da Fundação de Amparo à Pesquisa do Estado de São Paulo (Fapesp), já em 1964 tinha um curso de pós-graduação; bem como foi iniciativa do seu corpo docente a criação do Regime de Dedicação Exclusiva à Docência e Pesquisa (RDIDP), até hoje o regime de trabalho que mais garante direitos ao professor universitário no Brasil. Do outro lado, temos a Universidade Federal do Rio de Janeiro (UFRJ), que teve que esperar a Reforma de 1968 para instituir a pós-graduação e só contou com a Fundação de Amparo à Pesquisa do Estado do Rio de Janeiro (Faperj) em 1980.

Outra diferença das condições de ensino e pesquisa entre a USP e as outras universidades do país aparece, por exemplo, no fato de que, na década de 1960, a UFRJ era uma sigla que ganhava já o terceiro formato. A universidade foi fundada em 1920, como Universidade do Rio de Janeiro; reorganizada em 1937 e renomeada como Universidade do Brasil; e, reestruturada novamente, ganha o nome que tem atualmente um ano após o golpe de 1964. Cada nome corresponde a uma reforma universitária diferente, o que demonstra a fragilidade dessa instituição e sua "zona de intimidade" em relação ao campo da política, já que todas essas reformas acompanham as grandes viradas da República. Marcadas pelo autoritarismo, Rachel Esteves comenta a partir de sua análise da história dos cursos de Letras que, além da UFRJ, também na PUC-Rio, “a imposição, inicialmente, de um rígido controle ideológico por parte da Igreja e/ou do Estado na contratação de professores levou, evidentemente, à admissão de professores autodidatas e a uma baixa politização dos cursos ali ministrados." (grifo nosso) (LIMA, 1997, p.127)

A fundação da Pontifícia Universidade Católica (PUC) foi fruto do movimento que surge em fins da década de 1920 com a Associação dos Universitários Católicos e a posterior fundação do Instituto Católico de Estudos Superiores. Deste instituto saiu essa universidade que terá por objetivo conciliar a doutrina cristã com o rigor exigido pelas ciências e pelas artes. Na PUC-Rio, a maioria dos integrantes do corpo docente veio da Universidade do Distrito Federal (UDF) ou da própria Universidade do Brasil, visto que lá Alceu Amoroso 
Lima, um dos fundadores dessa universidade, encarregava-se das contratações que, se se pautavam pelo mérito, também evitavam professores declaradamente anticatólicos. A militância católica esmorecia com o passar do tempo e, ao longo dos anos, a PUC teria por objetivo apenas atender a demanda por vagas no ensino superior por parte das elites do Rio de Janeiro e de São Paulo. (cf. LIMA, 1997, p.72)

Por fim, a terceira universidade importante nesse período na trajetória dos críticos com os quais trabalhamos aqui é a Universidade Federal de Minas Gerais, cuja história talvez seja, de todas, a mais precária. Seu surgimento se dá no fim da década de 1920, com a fundação da Universidade de Minas Gerais, financiada pelo Estado e por particulares. Esta, como a USP, congregou as faculdades tradicionais e também tinha por meta formar gestores para o Estado. Contudo, apenas no fim da década seguinte seria criada, por iniciativa de um grupo de professores do Colégio Marconi, a Faculdade de Filosofia de Minas Gerais (UFMG), por ocasião da fundação da Faculdade Nacional de Filosofia (FNF), em 1939, no Rio de Janeiro. Entre esses professores estava Arthur Versiani Velloso, que há muito se correspondia com Émile Brehier a fim de estruturar uma futura Faculdade de Filosofia que permitisse o surgimento de "autênticos filósofos". (cf. LIMA, 1997, p. 74)

A Faculdade de Filosofia de Minas Gerais seria então inicialmente de caráter privado, já que desde 1939 contava com os recursos do Instituto Ítalo-Mineiro Guglielmo Marconi, instituto que era ligado à Igreja Católica e à Casa d'Itália, organização fascista. Apenas em 1942, com a ruptura do Brasil com os Aliados, o Estado de Minas Gerais autorizou a concessão de um auxílio financeiro que possibilitou, em 1948, a incorporação daquela à Universidade de Minas Gerais. Esta seria federalizada em 1949 e apenas a partir daí, quando integrada à UFMG, a Faculdade pode contar com uma sede própria e uma estrutura mínima para começar. Contudo,

logo que se constituiu, a FaFi- MG passou a sofrer uma grande rotatividade dos professores catedráticos, o que acabou gerando um clima de insegurança quanto ao seu destino. Os professores normalmente mantinham atividades paralelas das quais dependiam para o seu sustento, uma vez que a remuneração na cátedra ou era inexistente ou essa era praticamente simbólica. (LIMA, 1997, p.79-80)

A estratégia para sanar os problemas de um quadro docente não titulado na área, formado por escritores, jornalistas, advogados, autodidatas etc. foi investir numa política de incentivo de formação de docentes em outros centros universitários de dentro e de fora do Brasil. 
Fica assim evidente o modo como as instituições formais mais relevantes tiveram condições materiais absolutamente distintas de constituição, apontando claramente para a superioridade financeira da USP. Ora, essa superioridade não determina a priori a qualidade ou as condições de pesquisa na área de Letras dessa universidade, mas, sem sombra de dúvida implicou a atuação de redes corporativas de modo mais ou menos atuantes, como demonstra a reprodução endógena do corpo docente das grandes universidades, por exemplo, no caso da USP e da UFRJ ${ }^{19}$. Nesse sentido, notemos que não é à toa que tanto Schwarz como Portella se destacaram pela responsabilidade de serem espécies de "herdeiros" das instituições mais respeitadas, tal como vemos ser a relação de Antonio Candido com o primeiro na USP e a de Afrânio Coutinho com o segundo na UFRJ. Ainda que a ditadura tenha feito Roberto Schwarz se fixar na Unicamp, isso não determina o vínculo fundamental desse intelectual com a USP, pois se trata de um lugar simbólico que a assinatura Roberto Schwarz e seu trabalho ocupam, qual seja, o da radicalização dos princípios do materialismo, da dialética e do marxismo, que se encontravam no trabalho de Antonio Candido e de quem Schwarz foi professor assistente. Assim como no caso de Schwarz, também Portella foi, podemos dizer, encaminhado e se encaminhou para este lugar de "herdeiro" principal do fundador das Letras na UFRJ e da cadeira de Literatura Brasileira na Faculdade Nacional de Filosofia (FNF), Afrânio Coutinho, de quem foi auxiliar. O curso de pós-graduação da UFRJ foi inaugurado com a defesa da sua tese de doutorado, Fundamento da investigação literária (1974), e ele se tornou professor desse curso, efetivamente, com uma pesquisa considerada de excelência e posteriormente paradigmática para os estudos literários nessa universidade.

\footnotetext{
${ }^{19}$ A Letras da USP manteve uma rigorosa endogenia no sistema de ingresso no corpo docente. No caso do departamento de Teoria Literária e Literatura Comparada, até a quarta geração, ou seja, por quase três décadas, de 1970 a 1995, seu corpo docente foi composto de orientandos de Antonio Candido ou de orientandos seus (cf. NITRINI, 2004). No caso da UFRJ, os dados retirados a partir da tese da Rachel Esteves de Lima também impressionam. Ao longo da década de 1970, a pós-graduação desse curso de Letras tinha três áreas, Literatura Brasileira, Poética e Teoria Literária. 81 das 120 teses defendidas nessa época foram orientadas, respectivamente, por Afrânio Coutinho, Emmanuel Carneiro Leão e Eduardo Portella. Por fim, mesmo na PUCRio, que não pode se fechar tanto dado o caráter competitivo que devia manter, do ponto de vista de mercado, chegamos a ter um Affonso Romano Sant'Anna que, também fundador da pós-graduação, orientou um quarto (55 de 202) de todos os trabalhos defendidos na área de literatura brasileira entre os anos de 1972-1993 nessa universidade.

Não acreditamos que haja uma relação direta entre ser orientado formalmente por um professor e a semelhança de seu trabalho com o dele. Prova disso é que, entre os críticos aqui estudados, seja irônico que Costa Lima tenha sido orientado por Antonio Candido e Roberto Schwarz não. De qualquer forma, contudo, seria ingênuo esquecer que esses exemplos são recolhidos numa época de ditadura militar, ou pensar que este lugar de poder que é o do orientador não estabelece filtros desde o tipo de interesse que desperta ao ser procurado pelos alunos, até sugestões de encaminhamento e escrita da pesquisa. Não é isso, note-se bem, que define o corporativismo, mas o fato de parecer ligado a um longo ciclo no qual as universidades tendem a formar seus próprios professores.
} 
Também não é gratuito, no que diz respeito a essa correlação entre superioridade financeira e atuação das redes corporativa, o ritmo da publicação dos trabalhos aqui analisados. O trabalho de Schwarz chega a ganhar uma quinta edição em 2000 e o de Portella tem sua última edição, a terceira, logo no ano de 1981. Já os trabalhos de Silviano Santiago nunca terão uma segunda edição, e os de Costa Lima e Merquior esperam, respectivamente, 36 e 40 anos para receberem uma segunda edição, no caso da tese Verso universo em Drummond (1975), traduzida do francês novamente. A diferença entre esses tempos de publicação também não poderia apontar a qualidade do trabalho a priori, dado que esta não poderia ser estabelecida por sua demanda, como objeto livro, de mercado. Nesse sentido, acreditamos que ela aponta apenas formas de circulação do livro em que a universidade tem um papel fundamental no estabelecimento dos interesses comerciais, dado que esta última não só participa dos critérios para definir um trabalho acadêmico publicável como, a partir das bibliografias das disciplinas dos cursos de Letras, é crucial para a formação desse mercado consumidor. 


\subsection{A relatividade da autonomia nas compreensões das transformações} universitárias

Uma coisa é a existência do campo literário em termos de cargos e postos, outra é a sua dimensão do ponto de vista propriamente simbólico, ou seja, na medida em que as universidades passam a ser simbolizadas como espécies de "guardiãs" de valores e de um tipo de produção do conhecimento que seria de fundamental relevância cultural para o país. Nesse período imediatamente posterior à Reforma universitária de 1968, há um intenso debate sobre as novas regras do jogo do funcionamento do campo literário. Esse debate se dissipa em um processo de esquecimento da historicidade das diversas práticas que o constituem, todavia, no início da década de 1970, foram discutidos: a finalidade do curso de Letras; as novas práticas pedagógicas que surgiam; a necessidade de titulação na área e em níveis de pós-graduação para a carreira docente; o aumento da concorrência pelo maior número de agentes titulados no mercado; o aumento da procura por "capitais agregados" (curso de língua, curso no estrangeiro, orientador de prestígio etc.); a facilidade de publicação promovida pelo mercado editorial; a demanda por uma nova especialização do trabalho de pesquisa; as possibilidades nascentes de financiamento de pesquisa através do fortalecimento e surgimento de agências de fomento etc.

Notemos que dentro da diversidade de posicionamento dos críticos em relação a essas transformações universitárias, há em comum que, nessa época, a universidade não é um assunto prioritário, com exceção de Portella, que se torna ministro da educação em 1979, 10 anos depois da Reforma de 1968. Não podemos deixar de considerar, independente do que indica obviamente essa exceção, que esse era um contexto de ditadura no qual eram muitos os cálculos a se fazer para se colocar publicamente contra qualquer feito do regime militar. Fazer oposição no âmbito do ensino talvez também fosse tarefa hercúlea no sentido de ter de lidar com o "sentimento de derrota" em relação a um regime que implementava profundas reformas institucionais em setores estratégicos como a educação. Como se a universidade pública passasse a ser, nesse momento, um espaço pouco frutífero de engajamento ${ }^{20}$.

\footnotetext{
${ }^{20}$ Em entrevista concedida em 1978, vejamos a observação do de Schwarz: "seria interessante, por exemplo que um cidadão com boa leitura traçasse um programa de estudos comparativos necessários ao conhecimento apropriado da literatura brasileira. Isso no plano pacato da pesquisa universitária. Já no plano da interpretação da sociedade contemporânea, que afinal de contas é o que interessa mais [...]" (SCHWARZ, 1992, p. 121, grifo nosso)
} 
Deste modo, isso não quer dizer, contudo, que a ausência desse debate direto sobre universidade também não passe pelo que apontamos ter uma tendência histórica à afirmação da instrumentalidade do conhecimento, como o confirma uma divisão comum na época entre "acadêmicos" e "intelectuais", que diferenciava os que se dedicavam a interesses apenas determinados por sua especialidade e aqueles que voltavam sua produção de pesquisa para interesses públicos, comumente entendidos como os do país. Também confirma nossa hipótese o fato de que mesmo nesse contexto, outros agentes literários se arriscaram.

Assim, no debate que se trava após a publicação do artigo de Costa Lima, "Quem tem medo da teoria", publicado no jornal Opinião, o assunto virá para primeiro plano em textos assinados principalmente por poetas ${ }^{21}$. A discussão na imprensa é difícil de precisar, mas a narrativa de Antonio Carlos de Brito, Cacaso, em "Bota na conta do Galileu, se ele não pagar nem eu" (1975), publicado no mesmo jornal, nos ajuda a mapear. O debate teria começado com a publicação do poema "Exorcismo", de Drummond, no mesmo jornal, em abril do mesmo ano ${ }^{22}$. Ele teria acendido uma "faísca" entre os professores universitários e, segundo Cacaso, "se generalizava o reconhecimento e a repulsa contra o uso arbitrário e desmedido de teóricos e teorias na sala de aula" (BRITO, 1975, p.3). Assis Brasil, no Jornal de Letras; Emanuel Moraes, no Jornal do Brasil; Antonio Houaiss, na revista Visão e Ledo Ivo, no

${ }^{21}$ Ana Cristina César, por exemplo, em, "Os professores contra a parede" (1975), também respondendo ao texto "Quem tem medo da teoria", de Costa Lima, vai construir uma posição em relação às transformações universitárias naquele momento que a coloca em primeiro plano. A autora politiza o espaço da universidade, nas quais insere tanto o problema da opressão de classe como do corpo. Num esforço justamente de síntese das querelas de seu tempo, a autora aproveita o ensejo do artigo de Costa Lima e propõe a abertura de possibilidades de curso pensadas a partir de outros modelos teóricos, comportamentais e institucionais. Para ela, "acabar com a ideia de que os debates e as produções de conhecimento se desenvolvem no céu puro da verdade ou da ciência. Toda produção e toda transmissão de conhecimento está vinculada a uma posição ideológica e à posição de produtor dentro da instituição. Não se trata de rejeitar a possibilidade de produção teórica, ou um determinado tipo de produção teórica, mas de politizar as 'teorias', indicando os seus usos repressivos e recusando uma discussão puramente epistemológica." (CÉZAR, 1975, p.20, grifo da autora)

"Das relações entre topos e macrotopos / Do elemento suprassegmental / Libera nos, Domine // Da semia / Do sema, do semema, do semantema / Do lexema / Do classema, do mema, do sentema / Libera nos, Domine // Da estruturação semêmica / Do idioleto e da pancronia científica / Da reliabilidade dos testes psicolingüísticos / Da análise computacional da estruturação silábica dos falares regionais / Libera nos, Domine // Do vocóide / Do vocóide nasal puro ou sem fechamento consonantal / Do vocóide baixo e do semivocóide homorgânico / Libera nos, Domine // Da leitura sintagmática / Da leitura paradigmática do enunciado / Da linguagem fática / Da fatividade e da não fatividade na oração principal / Libera nos, Domine // Da organização categorial da língua / Da principalidade da língua no conjunto dos sistemas semiológicos / Da concretez das unidades no estatuto que dialetaliza a língua / Da ortolinguagem / Libera nos, Domine // Do programa epistemológico da obra / Do corte epistemológico e do corte dialógico / Do substrato acústico do culminador / Dos sistemas genitivamente afins / Libera nos, Domine // Da camada imagética / Do espaço heterotópico / Do glide vocálico / Libera nos, Domine // Da lingüística frástica e transfrástica / Do signo cinésico, do signo icônico e do signo gestual / Do clitização pronominal obrigatória / Da glossemática / Libera nos, Domine // Da estrutura exo-semântica da linguagem musical / Da totalidade sincrética do emissor / Da lingüística gerativo-transformacional / Do movimento transformacionalista / Libera nos, Domine // Das aparições de Chomsky, de Mehler, de Perchomock / De Saussure, Cassirer, Troubetzkoy, Althusser / De Zolkiewsky, Jakobson, Barthes, Derrida, Todorov / De Greimas, Fodor, Chao, Lacan et caterva / Libera nos, Domine.” (DRUMMOND, 2003, p.867) 
Globo: todos se manifestaram publicamente tanto contra os novos conteúdos ensinados, bem como contra o modo como eram ensinados.

Ana Cristina César, Cacaso, Drummond, Ledo Ivo, etc. foram enfáticos em apontar os "usos repressivos" da teoria literária que estavam nas práticas de ensino e pesquisa. Ora, o fato de que são os poetas que se lembram da relação de poder entre professor e aluno talvez já indique uma queda do poder simbólico do posto social de escritor, já que esses parecem estar, como os "alunos da universidade massificada", a princípio excluídos dos novos códigos necessários para falar com autoridade de literatura. O lugar de poeta, de escritor, de aluno, de resenhista, etc. parece começar a ficar sob suspeita de má-formação escolar, vamos dizer assim até que se prove o contrário. Naquele momento de instabilidade ainda foi possível que, no meio de discussões acadêmicas, os poetas não só foram autorizados a falar como suas intervenções tiveram um peso importante, coisa que tende a diminuir com o tempo. Nesse sentido, apesar dos diferentes posicionamentos, se podemos dizê-lo, os poetas que participaram do debate parecem "intuir" a tendência à hegemonização (portanto à homogeneização) da produção dos critérios de valoração tanto do estudo sobre a literatura como da própria literatura, por parte da universidade e do conhecimento acadêmico.

De modo muito distinto, os críticos falam das transformações universitárias, porém, em segundo plano, em detrimento, entre outras coisas, do debate sobre a chamada "invasão estruturalista", expressão que marca justamente a ideia de ocupação ilegítima, por parte daqueles que operam com o valor da independência intelectual no registro da nacionalidade ${ }^{23}$. Isso que se tornou quase que um topos daquele momento pressupõe uma noção do termo "estruturalismo" que foi empregado, por um lado, como reunião de um grupo de autores e textos que compartilham de uma qualidade comum e difícil de mapear tanto aqui como na França ${ }^{24}$. Por outro lado, ainda, o termo foi empregado com o sentido de designar um "método

\footnotetext{
${ }^{23}$ Notemos a frequência com que isso aparece no título de textos da época. Só entre as assinaturas com que lidamos, encontramos títulos como "Cuidado com as ideologias alienígenas" (1976), e títulos de capítulos como "As ideias fora do lugar" de Ao vencedor as batatas (1977), de Roberto Schwarz; e "O entre-lugar do discurso latino-americano" (1971), de Silviano Santiago. Todos esses títulos são marcados pela metáfora espacial e certo apego a esse valor da independência. Já no outro pólo do campo, no qual Merquior transita nesse sentido, pouco encontraremos títulos com esse caráter, já que eles se atêm mais diretamente à questão da crítica literária e sua relação com o estruturalismo, como o capítulo "Sobre alguns problemas da crítica estrutural" do livro Astúcia da mimesis (1972) e "O Estruturalismo dos pobres", de Merquior; o Apêndice I, "Crítica Literária e Estruturalismo" de Teoria da Comunicação Literária (1976) de Eduardo Portella e o livro Estruturalismo e Teoria da Literatura (1973) de Costa Lima.

${ }^{24}$ Como demonstra François Dosse em História do estruturalismo (1993, cf. 15-16), ainda que se possa fazer uma genealogia da palavra estruturalismo desde os primeiros indícios de seu emprego na arquitetura, passando pelos séculos XVII e XVIII, quando empregado em relações de analogia com os seres vivos, bem como chegando a ocupar um lugar fundamental para as ciências humanas no XIX, não só não é possível defini-la como fazê-lo ou empregá-la de modo definido seria ignorar tanto sua historicidade quanto a luta na qual seu emprego acontece nos diversos campos do conhecimento no século XX.
} 
estruturalista" ou "uma 'teoria estruturalista", também num registro generalizante, tendo como lugar comum ideias como a busca pela constituição de um "sistema", "episteme", "discursividade" por meio de "pares opositivos" e o questionamento da centralidade do sujeito nas preocupações filosóficas de ordem ontológica, fenomenológica, existencial etc.

De todo modo, seja num ou noutro registro, o debate em torno do termo foi, de diferentes maneiras, marcado por se subjugar a elementos heterônomos de toda ordem, sendo aquele que mais se sobressai nesse ideal de independência intelectual no registro nacionalista, com exceção de Silviano Santiago, como veremos. Naquelas décadas de 1960 e 1970, o termo"estruturalismo" foi fundamental para a distinção de assinaturas, instituições e posições políticas no campo literário e intelectual de modo geral. Veremos nos pontos 3.0 e 4.0 desta dissertação que, se não existe um único estruturalismo, muito menos há um estruturalismo no Brasil. Contudo, há o estruturalismo como nome, como modo de circulação e produção de textos, nesse sentido, vejamos nas passagens que se seguem que Merquior e Roberto Schwarz: por trás dessa belicosidade ideológica, podemos vislumbrar uma conivência bem conformista com a situação crítica da intelligentsia latino-americana e, em particular, com a crise da educação superior. Não é por acaso que o ator ou espectador por excelência do festival estruturalista é o aluno ou ex-aluno da universidade massificada. (MERQUIOR, 1975, p.12, grifo nosso)

É evidente que na França, aqui e ali, o estruturalismo teve aspectos extremamente combativos e produtivos. No Brasil não vi nada disso até agora. [...] Porque o estruturalismo no Brasil foi profundamente apolitico, enquanto na França é mais para gauchiste, digamos. É empenhado. Você pode não ver grande interesse - eu não vejo — também no estruturalismo francês, mas, de qualquer forma ele é empenhado." (SCHWARZ, 1979, grifo nosso)

Costa Lima e Portella, apesar de deixarem em segundo plano o problema da autenticidade nacional, também tocam no assunto de modo a confirmar a necessidade dessa autenticidade. Em 1978, Costa Lima aponta pontos negativos, predominantes, e positivos, em relação à recepção do estruturalismo no Brasil e afirma: "como nós somos basicamente auditivos, orelhões de informações alheias, de informações ouvidas (e quanto mais estranha / estrangeira a língua mais precioso o nosso conhecimento), claro que isso estabelece um choque com toda a tradição brasileira." (COSTA LIMA, 1981, p.214). Claramente a preocupação do crítico é que haja uma apropriação adequada das teorias no sentido de que é 
necessário romper, para tanto, com a superficialidade gerada por uma inautenticidade que chegaria às raias da superficialidade.

Eduardo Portella, por sua vez, em 1979, publica o texto "Crítica literária e estruturalismo", em que faz uma apresentação didática do que seriam características gerais do estruturalismo ao mesmo tempo que introduz sua conciliação deste com uma perspectiva ontológica heideggeriana. Posteriormente, veremos de modo aprofundado como Portella fez o que hoje parece ser uma associação inusitada. Por ora, apenas notemos que a única referência à relação entre estruturalismo e nacionalidade é irônica. Ao relembrar o problema da relação entre estrutura e história, comenta: "esta questão apenas seria suficiente para desaconselhar a pressa com que certos teóricos 'nacionais' se atiram ávidos na passarela do estruturalismo." (PORTELLA, 1979, p.157) Ora, claramente o crítico quer fazer parecer que a preocupação em haver 'teóricos nacionais' parece estapafúrdia. Contudo, a própria crítica à avidez desses teóricos não se separa da indicação de que são nacionais e de que deveriam, por isso, ter parcimônia no emprego de autores, ideias e conceitos tidos por estruturalistas.

Por fim, no caso de Silviano Santiago, vejamos a citação que se segue:

Não houve barreiras, não houve dificuldades, pra mim, em compreender o pensamento de Michel Foucault, o pensamento de Jacques Derrida, ou o segundo ou terceiro Roland Barthes [...] porque minha própria movência no Brasil e no estrangeiro já me encaminhava para a reflexão francesa pós1968, que poderia eventualmente conduzir a uma mudança gradual, e muitas vezes radical, no comportamento do ser humano (SANTIAGO, 2006, p.174, grifo do autor)

O crítico aponta como afinidade ("não houve dificuldades") em relação ao pensamento de Foucault, Derrida e Barthes, o que chamaríamos de interesses por leituras produzidos por espaços institucionais, autoridades, circulação etc. A trajetória cria disposições, mas isso não quer dizer que elas se realizem. Nesse caso, contudo, ela se realizou porque a primeira experiência universitária de Silviano Santiago, como vimos, na UFMG, foi marcada por uma instituição que via e teve que ver como positivo o intercâmbio com outros centros intelectuais. Numa lógica mesma de distinção, o crítico posiciona-se sobre o tema num registro que tende a ser a priori positivo, na medida em que há uma recusa ao que seriam mitos de autenticidade, pureza e superioridade cultural. No artigo "O entre-lugar do discurso latino americano", publicado originalmente nos EUA e traduzido para o português por ocasião da publicação de Uma literatura nos trópicos (1977), ele sustenta a tese geral de que é possível haver a inversão dos valores econômicos no âmbito da cultura. Para o crítico, naquele momento, 
descentralizou-se a cultura brasileira da cultura institucionalizada, aceita e aplaudida pelos "intelectuais", pelas universidades, pela ABL e pelos suplementos literários, de modo que o interesse pela cultura sofisticada dos grandes centros seria transferido para o marginalizado até então. (SANTIAGO, 2000, cf., p.157)

Silviano (2000, p.16) afirma que nos países colonizados os códigos linguísticos e religiosos "perdem seu estatuto de pureza e pouco a pouco se deixam enriquecer por novas aquisições, por miúdas metamorfoses, por estranhas corrupções, que transformam a integridade do Livro Santo e do Dicionário e da Gramática europeus. O elemento híbrido reina.” Nesse sentido, "a maior contribuição da América Latina para a cultura ocidental vem da destruição sistemática dos conceitos de unidade e de pureza". O crítico então reivindica essa contribuição e atribui as qualidades de "tradicional" e "reacionário" ao método, para ele bastante enraizado nos cursos de Letras das universidades brasileiras, que se atêm à pesquisa das fontes e influências, valorando o texto literário a partir disso. (SANTIAGO, 2000, cf. Ibidem, p.17)

Nesse sentido, o que Roberto Schwarz chamou de inautenticidade, Silviano Santiago vê como traço inerente a toda cultura. O segundo acaba por incorrer, contudo, numa ideia de apaziguamento ou de lutas entre iguais na relação entre as culturas, alimentando realmente um clima de adequação, de "no lugar", que se pode ver nessa ideia de "entre-lugar". Este seria conhecido pelo escritor latino-americano melhor do que pelo europeu ou americano porque, sendo vistos como imitadores, para eles teria sido negada desde sempre uma ideia romântica de invenção a partir do nada. Essa condição de dominação acabaria por afirmar, numa "praxis da escritura", "uma escritura do segundo texto [que] é em parte a história de uma experiência sensual com o signo estrangeiro.” (SANTIAGO, 2000, p.21)

De todo modo, com exceção do posicionamento do crítico mineiro, os outros parecem estar autorizados por um ponto de vista externo ao que seriam supostos consensos nacionais. É como se, de certa forma, todos já estivessem estado simbolicamente fora da grande caverna Brasil e, no emprego do termo estruturalismo, pudéssemos entrever uma espécie de narrativa do que foi visto lá fora e de como deve o crítico portar-se a partir disso. Há, nesse sentido, a sobrevalorização do "modo de apropriação" de textos filosóficos, sociológicos, literários etc. e que passa por identificar o que seria um dever-ser da relação entre nacionalidades. Isso implicaria o esmorecimento de um sentido das apropriações independente de um projeto cultural nacional, apenas interno à história da filosofia, da teoria literária, da literatura etc., ou seja, de um sentido que afirmasse a autonomia dessas discursividades. 
Acreditamos que o modo como essa independência intelectual nacional foi concebida e até mesmo vivida, no sentido de uma cultura acadêmica e intelectual, está absolutamente vinculado à história das fundações das faculdades de filosofia na primeira metade do século XX. Nesse sentido, não seria mera coincidência que as tentativas de construção de teorias literárias tenham vindo de lugares do campo intelectual que reconheciam a possibilidade de fazer filosofia no Brasil. No caso de Schwarz e Merquior, sem dúvida ressoa um ponto de vista presente no trabalho de Antonio Candido, mas já tornado central a partir dos cursos do professor João Cruz Costa (1945, p.21), que já criticava: “a filosofia no Brasil viveu sempre, é certo, sujeita às chegadas dos paquetes da linha da Europa”. Já no caso de Costa Lima e de Portella, com certeza o clima da Faculdade de Direito em que se formam e o ambiente intelectual de Recife, por mais diferente que sejam suas circulações nele, foram marcadas pela postura de Gilberto Freire, que também sempre questionou, assim como Silvio Romero o fez no XIX, o modo como no sudeste o intercâmbio cultural lhes pareciam se dar de uma forma subserviente.

Silviano Santiago, por sua vez, também teve contato, desde sua formação na UFMG, com o projeto de Versiani Velloso, que mais diretamente defendia essa possibilidade de fazer filosofia no Brasil. No caso da FFCL da USP, em que parece ter vencido a concepção de que primeiro era necessário formar uma geração de leitores e comentadores rigorosos e que, enquanto isso, a única coisa possível a fazer era história da filosofia, desprezando as tentativas filosóficas feitas por aqui, não houve autores que reivindicaram o lugar de teóricos da literatura. Além disso, a disciplina de Teoria Literária, fundamental para afirmação da autonomia do campo literário, pois voltada para a apreensão e entendimento do objeto literário, é o estudo mais próximo do discurso filosófico no âmbito dos estudos literários. Faz sentido pensar que suas possibilidades de desenvolvimento obedeçam ou pelo menos tenham que lidar com aquelas colocadas para a filosofia, disciplina claramente superior na hierarquia das disciplinas.

Essa distinção que acabamos de apontar acreditamos que seja organizadora de muitas outras, nisso que especulamos como historicidade do termo campo literário. Naquele momento, a oposição entre autonomia e heteronomia passava fundamentalmente pela obrigatoriedade da disciplina da Teoria Literária, confundida e equiparada, por vezes, com o termo generalizante "estruturalismo", e a sua implementação foi marcada fortemente pela distinção entre a tendência a uma postura de incentivo e abertura ou de desestímulo e esvaziamento do seu conteúdo. 


\section{As tomadas de posição em relação à teoria literária e à estética}

No capítulo anterior, levantamos elementos da tensão entre autonomia e heteronomia do campo literário no período que nos interessa. Nesse sentido, vimos como a instituição da obrigatoriedade da disciplina de Teoria Literária nos cursos de Letras foi fundamental para a mudança nos parâmetros de rigor dos estudos literários. As competências exigidas na análise do texto literário passam então a ser questionadas, além disso, vimos esse fato de afirmação de autonomia do campo produzir um verdadeiro furor na época. Agora, caberia apontar como cada estudo literário de nosso corpus principal vive essa tensão entre autonomia e heteronomia, especialmente em suas dimensões teórica e analítica. Relembrando os títulos que compõem esse corpus: A perversão do trapezista: o romance em Cornélio Penna (1976), de Luiz Costa Lima, Verso Universo em Drummond (1975), de José Guilherme Merquior, Ao vencedor as Batatas (1977), de Roberto Schwarz, Fundamentos da investigação literária (1974), de Eduardo Portella e Carlos Drummond de Andrade (1976), de Silviano Santiago.

No âmbito da teoria e da análise literária, a oposição entre autonomia e heteronomia reaparece entre compreensões do literário em que a literatura é negada enquanto discurso capaz de produzir seu próprio conhecimento e os entendimentos do literário marcados pela transposição de operadores de análise de outras discursividades. Evidentemente que essas divisões se misturam e essa própria transposição pode ser feita com mais ou menos mediação. $\mathrm{Na}$ época em que estudamos, a característica que primeiro salta à vista como indício de heteronomia das análises são as marcas de presença de um ideal científico de objetividade, ainda que seja para negá-lo. A pretensão à objetividade científica se coaduna com outros elementos que marcaram o polo da heteronomia do campo literário e se liga a uma visão instrumental da literatura na medida em que este se torna meio para confirmação de um modelo interpretativo não literário e, frequentemente, de hipóteses não literárias.

Nesse sentido, é curioso que o trabalho de Costa Lima esteja mais próximo do de Schwarz do que o de Merquior, que compartilha da mesma compreensão do objeto literário que ele. Isso porque os trabalhos de Roberto Schwarz e Costa Lima colocariam, no caso do primeiro, a ciência econômica no topo da hierarquia disciplinar, como ciência da infraestrutura que determina a superestrutura; e, no caso do segundo, ocorre o mesmo com uma perspectiva científica da antropologia estrutural de Lévi-Strauss como modo de compreensão da literatura. Ou seja, a própria escolha do tipo de interdisciplinaridade 
legitimadora do discurso analítico já traz, por si, o caráter dessa objetividade, além da transposição de todo um vocabulário e categorias de operação analítica.

Contudo, distancia esses trabalhos a própria visão da linguagem artística, no caso, como expressão do conteúdo por um lado e como sintagma de um paradigma por outro. Nossa comparação, nesse sentido, não se sobrepõe ao fato de que o trabalho de Costa Lima, se comparado aos trabalhos de Schwarz e Merquior, tem uma forma de compreensão do literário que afirma significativamente a autonomia do literário, já que, no caso do seu trabalho, a objetividade científica é um elemento heterônomo em função da construção de um elemento autônomo, e que considera fundamental, qual seja, à construção de uma teoria da literatura.

O trabalho de Merquior, por sua vez, apesar da distância dessa tendência à objetividade científica, atém-se a uma espécie de "atualização dos preceitos da estética" por meio da análise na qual a literatura tem fundamentalmente a função de exemplo de reflexões históricas, sociológicas ou filosóficas, fazendo seu trabalho compor, junto do de Schwarz, aqueles que compreendem a literatura de modo mais heterônimo. Com isso, queremos apontar que para se posicionar no extremo do polo da heteronomia do campo literário seria necessário afirmar no próprio projeto do estudo literário uma compreensão da literatura como representação das contradições sociais. Nos casos dos trabalhos de Costa Lima, Silviano Santiago e Portella, há o compartilhamento dessa compreensão, mas ela escapa a seus projetos, e o realismo que, de certa forma compartilham, não se reduz a representações sociais do nacional, ainda que, como veremos, acabem se atendo a ele.

Nos trabalhos de Silviano Santiago e Portella, a interdisciplinaridade se dá, no caso do primeiro, entre a sociologia, a filosofia e a psicanálise, e, no caso do segundo, se atém à filosofia. Em ambos, há uma busca por essas disciplinas de modo a privilegiar uma linguagem e uma perspectiva de fuga do que seria um discurso cartesiano que "explique" o objeto literário num registro demonstrativo de verificabilidade e que seria exigido por essa tendência à objetividade científica. No caso do trabalho de Silviano Santiago, como vimos, o que temos é uma linguagem analítica que opera com as imagens selecionadas ou criadas a partir dos poemas e que compõem uma leitura geral. A tese, portanto, não tem como ser amarrada com argumentos de ordem demonstrativa, pois, justamente, o modo como se dá o jogo de ausência e presença de enunciados, na maior parte das vezes sobre sexualidade, tema de interesse que elege, é que compõe o sentido total de sua análise da obra de Drummond. Eduardo Portella também fugirá de uma lógica demonstrativa ao escrever, como ele mesmo diz, de modo circular, num movimento próprio ao das ontologias e fenomenologias, no qual o que se diz sobre o texto literário é confirmado apenas por naquilo que o torna, para ele, entre-texto, 
linguagem, ou seja, enquanto justamente possibilidade de devir, isto é, como fato no sentido heideggeriano do termo e não no sentido comum.

Apesar do agrupamento dos trabalhos que fizemos acima, veremos, contudo, que em todos eles está presente como problema crucial da legitimação de suas análises a objetividade do conhecimento sobre a literatura, pautada por modelos interpretativos não literários. $\mathrm{O}$ marxismo e seus diferentes desdobramentos sociológicos, as diferentes psicanálises, os diferentes pontos de vista e âmbitos linguísticos, as diferentes visadas antropológicas, as distintas perspectivas filosóficas etc., cada um desses pontos de vista, quando trazidos para os estudos literários, institui os limites tanto do conhecimento sobre o texto literário, como do que se pode conhecer a partir dele. Nesse sentido, parece que em 1960 e 1970 é como se tivéssemos uma espécie de acirramento das distinções epistemológicas nos estudos literários, na medida em que as diferentes disciplinas preponderantes em cada trabalho servem como lentes que se excluem, mas que também se complementam e se misturam em relações de todo o tipo. 


\subsection{Caso a caso}

\section{Ao vencedor as batatas}

Pois bem, vejamos de que maneira em Ao vencedor as batatas (1977) está presente uma compreensão do objeto literário que, dentro dos trabalhos de nosso corpus, nos fez colocá-lo no pólo extremo daqueles que mais carregam traços de um entendimento heterônomo do ficcional. Primeiramente, a compreensão do objeto literário que nele aparece pressupõe, antes de mais nada, uma concepção de tempo dialética e materialista zelosa de uma objetividade histórica fundada nos escritos econômicos e filosóficos de Marx. Isso leva Schwarz a organizar a exposição de sua pesquisa em termos de tese, antítese e síntese. Há então uma tese apresentada no segundo capítulo, em "A importação do romance e suas contradições em Alencar", seguida da proposição de uma antítese, em "O paternalismo e suas racionalizações nos primeiros romances de Machado". Tese e antítese se constituem, na história da literatura, respectivamente, de Senhora (1875), de José de Alencar, e dos quatro primeiros romances de Machado de Assis, deixando para Memórias Póstumas de Brás Cubas (1881), romance analisado em Um mestre na periferia do capitalismo (1990), a síntese de um processo de compatibilização entre a forma romance e a matéria local ${ }^{25}$.

Esse processo se dá por meio de uma compreensão teleológica da história da literatura, na qual ela teria caminhado para uma direção final, no caso em questão, para os romances de alta qualidade da segunda fase de Machado de Assis. A análise da obra de José de Alencar, entrevista na análise particular de Senhora, é feita na direção de elogiá-la por estabelecer um parâmetro, ainda que equívoco, do romance no Brasil. Ora, esse parâmetro tem um valor em si porque ele permite a negação, apontada na análise dos romances da primeira fase da obra de Machado, e depois a síntese, em sua segunda fase. Segundo o crítico, eles teriam o mérito de atualizar este gênero literário na medida em que o que antes era periférico no romance de Alencar, qual seja, os dilemas dos pobres, relativos ao favor e aos dramas do paternalismo, passa para o centro dos romances de Machado.

Vejamos que a compreensão do objeto literário que aqui opera pressupõe, como o termo sociedade, que ele possui uma lógica já dada e que deve ser revelada:

o fato de experiência, propriamente literário, é outro, e é a ele que a boa teoria deve chegar: está no

\footnotetext{
${ }^{25} \mathrm{Na}$ edição com que trabalhamos há, inclusive, uma "Explicação ao leitor": "Esta é a metade de um estudo sobre Machado de Assis. Como ele tem relativa independência, e a segunda parte talvez ainda demore, achei preferível não esperar, e publicar em separado os capítulos que se seguem.” (SCHWARZ, 1977, p.9)
} 
acordo ou desacordo entre forma e matéria a que se aplica, matéria que esta sim é marcada e formada pela sociedade real, de cuja lógica passa a ser representante, mais ou menos incômoda, no interior da literatura. (SCHWARZ, 1977, p.42)A passagem acima opera uma compreensão do objeto literário que pressupõe a dicotomia entre forma e matéria e essa divisão ainda se desdobra na ideia de que essa matéria tem uma "lógica", uma "forma", e é esta última que se constitui como matéria no caso da literatura que, por sua vez, é formalização do real. Esta oposição entre matéria e forma é acompanhada de outra, que costuma lhe ser paralela, relativa à distinção entre literatura e sociedade, divisão que remete a categorias que surgem no século XIX, presentes na obra de críticos como Sílvio Romero, e permanecem no XX, na obra de críticos como Antonio Candido, caso pensemos nacionalmente. De todo modo, a herança deixada por pensadores como Taine ou Comte da busca pela lógica científica das transformações históricas e sociais se manteve na maior parte das estéticas e teorias literárias do século XX. No caso do trabalho de Schwarz, ela chega, por meio da teoria de Welleck e Warren, às estéticas de Theodor W. Adorno e György Lukács. Apesar das diferenças, tais autores reservam momentos separados da descrição do que está fora do texto, a sociedade, e o que está dentro, numa relação de "aplicabilidade de lógicas" ${ }^{26}$. Para nos atermos expressamente às palavras do crítico:

eis o que interessa: passando a pressuposto sociológico uma parte das condições históricas originais reaparece, com sua mesma lógica, mas agora no plano da ficção e como resultado formal, neste sentido, formas são $o$ abstrato de relações sociais determinadas, e é por aí que se completa, ao menos ao meu ver, a espinhosa passagem da história social para as questões propriamente literárias, da composição - que são de lógica interna e não de origem. (SCHWARZ, 1977, p.39, grifo nosso)

Veremos que, se no caso de Costa Lima e Silviano Santiago é o pressuposto antropológico e psicanalítico, respectivamente, que permite a objetividade da ponte entre literatura e sociedade, aqui é o pressuposto sociológico. Contudo, isso não quer dizer que haja uma exclusão ou um banimento total das outras discursividades. Nesse caso, é fundamental que a ideia de forma social, apesar de não ser voltada para as metodologias da psicanálise, não as despreze como conhecimento, assim como veremos ser a presença da sociologia no trabalho de Costa Lima. Assim, um exemplo poderia ser retirado do comentário de Schwarz sobre Iaiá Garcia (1878). Ao falar da austeridade do personagem Luis Garcia e apontar o modo como no romance é humilhante, dentro da lógica do favor, que os dependentes

\footnotetext{
${ }^{26}$ Ver sobre isso o capítulo "Literatura e sociedade" de Teoria da literatura (1948), de René Wellek e Austin Warren, e "Palestra sobre lírica e sociedade" em Notas de literatura (2003), de Theodor W. Adorno. Apesar da divisão literatura e sociedade ser comum, são grandes as diferenças entre esses trabalhos. O manual de Welleck e Warren tenta se despedir da estética e da hermenêutica enquanto Adorno, por sua vez, se atém à construção de uma estética de fundamento hegeliano.
} 
compartilhem seus sonhos e aspirações com os dominantes, Schwarz (1977, p. 125) afirma que

existe uma espécie de libidinagem do paternalismo - abordada obliquamente em Helena - que a Machado neste momento causava horror, em cuja exploração entretanto ele iria se comprazer ao infinito nos romances da segunda fase $[. .$.$] de que ele seria matéria por excelência.$

Contudo, a psicanálise não interessa como metodologia, epistemologia, vocabulário principal etc. e a historicidade supostamente imanente ao texto literário é depreendida por meio de uma leitura alegórica, na medida em que identifica nele elementos de confirmação de conceitos e formulações sociológicas totalizantes, aqui, formas sociais. Esses conceitos e formulações sociológicas carregam pretensões à objetividade científica, na medida em que são acompanhados de modo crucial por um vocabulário retirado do âmbito da economia, ciência humana e exata, simultaneamente:

em suma, também nas Letras a divida externa é inevitável, sempre complicada, e não é parte apenas da obra em que aparece. Faz figura no corpo geral da cultura, com mérito variável, e os empréstimos podem facilmente ser uma audácia moral ou política, e mesmo de gosto, ao mesmo tempo que um desacerto literário. (SCHWARZ, 1977, p.36, grifo nosso)

Infraestrutura e superestrutura caminham juntas, mas negan do o que seria uma relação de determinação direta do primeiro em relação ao segundo, o crítico se apóia na ideia de favor não só como mediação fundamental entre ambas, mas como conceito que, enquanto tal, contribuiria para um "estudo racional do processo produtivo no país" que, "assim como a sua modernização continuada, [...] era sem propósito no Brasil.” (SCHWARZ, 1977, p.15). Apesar de ser incompatível com as ideias liberais, o favor as absorveria e as deslocaria, bem como originaria um "padrão particular" no qual elas justificariam a arbitrariedade das ações das classes dominantes. Nesse sentido, as ideias liberais aqui não seriam propriamente ideologia, visto que não serviam para falsear a realidade, mas "ideologia de segundo grau", pois sua função era, além de dar "relevo social" à pequena elite que a empregava, inviabilizar qualquer "intenção cognitiva e de sistema" (SCHWARZ, 1977, p.17) no que toca à compreensão da realidade.

Assim, se no âmbito da infraestrutura a escravidão era a "relação produtiva fundamental", na esfera da cultura, era o favor ou o "nexo efetivo da vida ideológica" (SCHWARZ, 1977, p.15-16), dado que, ao contrário do que ocorrera na Europa, os homens livres dependiam desse favor para exercer seu trabalho, segundo a tese construída pela historiadora Maria Silvia de Carvalho Franco em Homens livres na sociedade escravocrata $(1976)^{27}$. De acordo com a autora, aqui teríamos o favor como representação social da

\footnotetext{
${ }^{27}$ Schwarz também se apoiará nos estudos "Introdução ao estudo da emancipação política" (1968) de Viotti da Costa e Capitalismo e escravidão, de Fernando Henrique Cardoso. A historiadora apresenta o diagnóstico do
} 
igualdade, tão ideológica quanto a representação de igualdade da burguesia europeia. Ambas seriam compensações simbólicas da exploração do trabalho, ideologias, uma da sociedade burguesa e outra da sociedade escravocrata ${ }^{28}$.

Schwarz (1977, p.16) então retira a reflexão da autora do âmbito da historiografia em que foi feita e a relê no âmbito de uma hipótese sociológica generalizante, pensando o favor como prática de um longo tempo histórico, como lógica de relação social característica do Brasil:

o favor é a nossa mediação quase universal e sendo mais simpático do que o nexo escravista [...] é compreensível que os escritores tenham baseado nele a sua interpretação do Brasil, involuntariamente disfarçando a violência, que sempre reinou na esfera da produção.

As ideias liberais, portanto, não chegam a ser uma forma de compreensão do mundo no Brasil, mas "ligam-se ao momento expressivo, de auto-estima e fantasia, que existe no favor" (SCHWARZ, 1977, p. 18). Sob a sua égide, elas tinham como lastro histórico uma sociedade cujo parâmetro do trabalho escravo excluía o seu papel propriamente ideológico de mascaramento das relações de exploração. Assim, acabariam por funcionar como uma espécie de panaceia sem lógica, guiada por modismos sem consistência, pois desvinculada de um tipo de "núcleo duro" da ideologia local, a escravidão, esta sim indicativa do modo de produção colonial e na qual se desdobra o favor. Este último seria então a única forma corrente de representação ideológica da igualdade, pois concedida pelos poderosos sem estar vinculada ao mérito do trabalho. As satisfações que as elites devem dar aos ideias liberais, como a liberdade, igualdade e fraternidade, colocam, antes de mais nada, um problema de forma das relações sociais, ou seja, também de lógica. Isso porque, operando dentro da lógica do favor, as relações entre favorecedor e favorecidos atribui malandramente "independência à

\footnotetext{
“conjunto ideológico" que faz conviver ideias liberais e escravidão, e o sociólogo aponta outra racionalidade de um modo de produção de base escravista.

${ }^{28}$ Caberia notar que é no modo de compreensão da particularidade nacional que o crítico e a historiadora divergem. Segundo a própria autora aponta em entrevista cedida à revista Almanaque, em 1976, a formulação "ideias fora do lugar" de Schwarz operaria dentro de uma lógica dualista, que opõe termos como "metrópole e colônia, atraso e progresso, desenvolvimento e subdesenvolvimento, tradicionalismo e modernização, hegemonia e dependência [...]" (FRANCO, 1976, p.61), que teria como pressuposto o fato de que "se reconhece na metrópole o centro produtor das relações sócio-econômicas e a colônia como seu produto" (Ibidem, p.61.) Para a historiadora o problema seria justamente a separação e exterioridade dos termos desse pressuposto, dado que estabelecem entre eles uma relação de causalidade e de ordem, no sentido de precedência da metrópole no que toca às transformações sociais e econômicas. Nesse sentido, apesar do esforço crítico de Schwarz em "Nacional por subtração", acreditamos que o crítico se mantém dentro desse paradigma de compreensão, contrário à afirmação da autora de que "colônia e metrópole não recobrem modos de produção essencialmente diferentes, mas são situações particulares que se determinam no processo interno de diferenciação do sistema capitalista mundial, no movimento imanente de sua constituição e reprodução. Uma e outra são desenvolvimentos particulares, partes do sistema capitalista, mas carregam ambas, em seu bojo, o conteúdo essencial - o lucro que percorre todas as suas determinações. Assim, a produção e circulação de ideias só podem ser concebidas como internacionalmente determinadas, mas com o capitalismo mundial pensado na forma indicada, sem a dissociação analítica de suas partes." (FRANCO, 1976, p.62)
} 
dependência, utilidade ao capricho, universalidade às exceções, mérito ao parentesco, igualdade ao privilégio etc." (SCHWARZ, 1977, p. 18). Ou seja,

em matéria de racionalidade, os papéis se embaralhavam e trocavam normalmente: a ciência era fantasia e moral, o obscurantismo era realismo e responsabilidade, a técnica não era prática, o altruísmo implantava a maisvalia etc. (SCHWARZ, 1977, p. 15, grifo nosso).

Ora, o fato do crítico se apoiar na tese de Maria Sílvia de Carvalho Franco para, por meio da leitura de textos literários, propor uma hipótese sociológica coloca o trabalho de Schwarz como aquele que, dentro do nosso corpus, mais apresenta elementos que marcam a compreensão heterônoma destes. Isto porque além de operar no projeto do seu estudo com uma ideia de literatura como representação das contradições sociais, sua análise literária é construída em função de uma hipótese fundamentalmente não literária, ainda que ela seja apontada detalhadamente nos romances e apresente tanto uma hipótese quanto a organização da obra de Machado de Assis, a partir da passagem do romantismo de Alencar aos seus romances.. A secundariedade das hipóteses literárias também é confirmada pelo fato de que o tema e o enredo, elementos literários que mais merecem destaque na leitura do crítico, servem de comprovações de sua leitura alegórica, na qual o texto literário deve representar suas construções sociológicas totalizantes.

Para o crítico, em A mão e a luva (1874), Machado reivindicava "o paternalismo ilustrado [...], contra a estilização romântica dos impasses da vida moderna" (SCHWARZ, 1977, p.100), que estaria presente em Helena (1876). Nesse romance, os conflitos morais permaneceriam no centro e os de interesse à margem: "a despeito das exigências radicais, a contradição central de Helena é antes contingente e periférica, ao passo que o plano real e necessário está espalhado pelas franjas do romance" (SCHWARZ, 1977, p.100). Apenas em Iaiá Garcia (1878), por sua vez, tido como o melhor dos romances dessa fase, “em lugar das questões algo genéricas dos livros anteriores [...] passam para a literatura e serão matéria problemática, de primeiro plano [...] uma porção de expressões e noções ligadas à prática do paternalismo, que não haviam ainda merecido honra." (SCHWARZ, 1977, p.114). Pensaremos isso do ponto de vista do valor no capítulo seguinte, por ora, apenas notemos que não só a valorização, mas o próprio entendimento da historicidade desses romances se dá por meio da identificação dos enredos e dos temas como representações da convivência entre valores do mundo burguês e do paternalismo.

\section{Verso universo em Drummond}


Notemos que, aparentemente, Merquior, Costa Lima e Portella tiveram um afastamento semelhante no que toca às estéticas e teorias literárias próximas ao marxismo, principalmente aquelas marcadas pela interlocução com Sartre e com o que identificam como marxismo dogmático, chegando Merquior a formular o reducionismo da tradição dialética como conceito (cf. MERQUIOR, 1969, p. 258-84). Portella publica, em 1963, Literatura e realidade nacional, no qual investiga problemas da historiografia literária nacional e propõe uma crítica literária engajada. Apesar da preocupação sartreana, o heideggerianismo já é a principal chave de compreensão do crítico e é nela que baseia seu esforço de interlocução e contribuição para a tradição dialética. Em Dimensões III (1965), Portella aponta, citando Heidegger $^{29}$, que:

"a linguagem é a casa do ser", é a dimensão obrigatória de todos os caminhos do pensamento. A definição do sentido, que se esconde na semântica das palavras expressivas daqueles processos, porá a descoberto a função dialética específica de cada um deles. O espaço assim aberto possibilita a visão mais completa da identidade e diferença que compõem a reflexão revolucionária de Marx e a reflexão especulativa de Hegel. (PORTELLA, 1965, p. 68)

Para que um especialista hoje não fique chocado com a aproximação do crítico, é necessário lembrar que naquele período foram muitas as tentativas de aproximar a tradição dialética de um heideggerianismo. No caso de Costa Lima, também encontramos esse diálogo duplo com o marxismo e o heideggerianismo, por exemplo, em seu livro de estreia Porquê literatura (1966), no qual afirma que:

a tarefa da literatura continuará a ser, agora como antes, a de atingir e a de trazer na palavra a raiz das coisas onde se deposita a raiz do homem [...], os métodos novos apresentados ainda não fecundam uma tradição de apreensão do humano e não apenas uma dimensão de novidade experimentalista. [...] O engano do notável crítico húngaro G. Luckács é neste ponto bastante ilustrativo. (COSTA LIMA, 1966, p.38)

Ora, de modo contrário a Costa Lima e Portella que, nesses meados de 1970, abandonam a perspectiva marxista no âmbito da interpretação literária, Merquior se mantêm dentro dela, mas a partir de uma crítica radical. Em 1969, Merquior publica Arte e sociedade em Marcuse, Adorno e Benjamin. Vejamos o que o crítico afirma:

a justaposição das reflexões de Walter Benjamin - cujo método Adorno (em Prismas) reconhece não se ter jamais servido de uma mediação universal - e de Martin Heidegger nos serviu como prova de que o entrosamento da análise histórica com a reorientação da visão do Ser e do modelo prático/teórico da natureza humana não leva a nenhuma fixação em qualquer dos pólos da alternativa otimismo/pessimismo, e sim à valiosa reconquista do sentido da esperança, que é por si só operadora daquela alternativa. (MERQUIOR, 1969, p. 291-2)

\footnotetext{
${ }^{29}$ A frase citada abaixo está em Cartas sobre el humanismo, de Martin Heidegger. Tradução de Tafael Gutierrez Girardot. Madrid: Taurus, 1959, p.7.
} 
Essa diferença nas escolhas, contudo, não implicou uma oposição de interesses no caso dos trabalhos de Costa Lima e Merquior, como o demonstra o interesse desses autores pela obra de Lévi-Strauss. No caso do primeiro, ele lança Estruturalismo e Teoria da Literatura (1973), livro relativo à possibilidade de alçar a reflexão de Lévi-Strauss sobre a arte ao estatuto de teoria literária, e só depois publica Metamorfose do silêncio (1975) e $A$ Perversão do trapezista (1976), livros de análise literária. No caso de Merquior, ele lança, no mesmo ano de Verso universo em Drummond (1975), a tradução do seu livro A estética de Lévi-Strauss (1975), comentário no qual investiga o conceito de arte dentro dos limites da obra do antropólogo. Contudo, esse interesse é compartilhado de maneiras absolutamente distintas e isso aparece, fundamentalmente, no modo como cada um se arrisca, antes de mais nada, em projetos que são de naturezas distintas: uma estética e uma teoria literária. Costa Lima almejava construir o que seria uma teoria literária, ou seja, um modo de compreensão próprio ao objeto literário, mas fundamentado num modo de entender mitologias indígenas; enquanto no trabalho de Merquior, cujas pretensões são da ordem do comentário, há uma preocupação mais geral em se manter dentro das formulações do antropólogo.

Assim, o estudo de Merquior sobre a arte na obra de Lévi-Strauss não só é denominado A estética de Lévi-Strauss (1975) como é dividido em três partes comumente presentes nas estéticas da arte: a) a relação entre arte/sociedade, na qual se atém à passagem sobre as pinturas dos Kadiwéu, em Tristes trópicos (2010); b) o conceito abstrato de arte, no qual se concentra nas ideias de "significante flutuante" e de "modelo reduzido", esta última presente no primeiro capítulo de Pensamento Selvagem (2010); c) uma periodização da arte em tempos de longa duração, como no terceiro capítulo em que, por fim, se detém em $A$ origem dos modos à mesa (2004), no tópico "O papel da arte na civilização mecânica", ao fazer uma caracterização geral da arte moderna sob o signo do individualismo e do enfraquecimento da significação ${ }^{30}$.

\footnotetext{
${ }^{30}$ Segundo o crítico, a própria visão da arte presente no trabalho do antropólogo estaria mais próxima do que entende por estética, dado que teria uma visão entrópica do gênero romance, ou seja, como gênero degradado. Em A origem dos modos à mesa (2004), na parte "Do mito ao romance", o antropólogo compara a evolução dos mitos ao folhetim, gênero fundamental para a construção do romance no século XIX: "algo de irreversível ocorre, enquanto uma mesma substância mítica sofre essa série de operações. Como a roupa torcida de uma lavadeira para espremer, a matéria mítica que contém, a matéria vai deixando escapar seus princípios internos de organização. Seu conteúdo estrutural se dissipa. No lugar das transformações vigorosas do início, só se vêem, no final transformações exauridas. [...] compreende-se porque essas narrativas exóticas lembram tanto um gênero tão popular quanto o delas, mas ligado aos poderosos meios técnicos e às necessidades vulgares da sociedade industrial, o folhetim. Também nesse último caso trata-se de um gênero literário que retira sua substância degradada de modelos e cuja pobreza cresce à medida que se afasta dos originais." (LÉVI-STRAUSS, 2004, p.117) A passagem acima deixa claro que, pelo menos naquele momento, o antropólogo apresenta uma visão entrópica das manifestações artísticas, no sentido de enquadrá-las numa espécie de evolucionismo às avessas, no qual elas tendem a surgir de modo originalmente autêntico e depois a se degenerarem com o acréscimo de elementos externos. De todo modo, progresso e entropia apontam para sentidos opostos, mas ambos
} 
Tanto no caso dos trabalhos de Costa Lima como no de Merquior, a antropologia estrutural permitia uma alternativa dentro desse momento de maior instabilidade na hierarquia tradicional entre historiografia e a sociologia. Não à toa, assim como Costa Lima distinguirá a problemática estética da sistêmica, como veremos, Merquior opõe a "interpretação estrutural" à "pesquisa histórica” (MERQUIOR, 1975a, p.92). Essa é a dicotomia que a crítica literária precisaria superar e a condição para tal é aceitar a dupla condição para a objetividade do método estrutural: a análise linguística e a invenção etnográfica. Esta última, cuja função teria, entre outras, a de criticar a hermenêutica de Dilthey e Schleiermacher, não dispensaria, contudo, a perspectiva histórica, o que o permitiria retomar Panofsky, historiador que o antropólogo autorizará como único que conseguiria ter sintetizado a análise estrutural e a história como campo combinatório (MERQUIOR, 1975a, cf. p.88): "Panofsky está sempre realizando uma espécie de iluminação dos laços estruturais profundos entre uma obra ou um estilo e as tendências histórico-culturais, sem cair nunca numa ótica reducionista" (MERQUIOR, 1975a, p.90). Para Merquior (1975a, p.94), fica subentendido ser esse o modelo de análise que, elogiado por ter um "rigor não dedutivo", opera em seu livro de análise, Verso universo em Drummond (1975).

Ora, notemos que, antes de mais nada, chama a atenção o abandono que Merquior faz de sua reflexão sobre a arte na obra de Lévi-Strauss em sua análise. A dimensão da reflexão epistemológica não integra, deste modo, a raiz da sua prática analítica, de modo que teremos o estudo de Merquior como "precursor”, em nosso corpus, da futura geração de especialistas, ao colocar a relação entre literatura e as disciplinas que dariam conta do real como fundamentalmente ilustrativo. Ao contrário de Schwarz, Portella, Costa Lima e Silviano Santiago, que viram a relação com as outras disciplinas numa via de mão dupla, na qual a análise e a teorização literária querem contribuir para as outras disciplinas e discursividades, Merquior abdica dessa ambição de antemão, separando teoria e análise.

Essa separação implicou que, dos críticos que se esquivam da tendência à objetividade científica, quais sejam, Silviano Santiago e Portella, ele é o único que o faz via historiografia hermenêutica. Daí que, nesse sentido, em Verso universo em Drummond (1975), Merquior privilegia categorias de análise que compreendem grandes unidades temporais artísticas e traços de estilo, como no caso dos conceitos de mescla de estilos, de Auerbach, ou o estilo da idade mítica de Broch, cruciais para a leitura de poemas particulares, dos livros de poesia como um todo e para o fio que alinhava as fases da obra poética de Drummond.

compartilham da mesma concepção historiográfica que procura estabelecer um sentido definido e coerente para as transformações históricas e que é um dos pressupostos fundamentais da historiografia de caráter romântico. 
Como o trabalho de Schwarz, Merquior se assemelha em abdicar da discussão tanto da literatura como representação como das categorias da historiografia literária romântica. Logo no início de Verso universo em Drummond (1975), encontramos a manutenção do modernismo como unidade temporal que, apesar de abrigar estilos diferentes, tem em comum elementos que claramente operam dentro de um modelo dedutivo de características gerais de escolas literárias: “o emprego de uma língua literária maleável e nacionalizada [...] a entronização do experimentalismo" (MERQUIOR, 1975c, p.5) dentro da qual a obra de Drummond deve ser posta.

O traço mais marcante da presença dessa historiografia sem dúvida é a compreensão da obra de um autor dentro da metáfora biológica herdada do século XIX. No caso da obra de Drummond, seriam projetados "quatro períodos do estilo poético de Drummond" (MERQUIOR, 1975c, p.4) que caminham para uma ideia implícita de maturidade, não necessariamente positiva, como veremos, do ponto de vista do valor literário. Vejamos, por exemplo, que na conclusão do livro o autor elogia a capacidade de Drummond em "apreender o sentido profundo da evolução social e cultural de seu país” (MERQUIOR, 1975c, p.243), havendo uma coincidência entre o seu trajeto empírico, que vai do interior de Minas Gerais para o Rio de Janeiro, com o trajeto do Brasil, que agora se urbanizava ${ }^{31}$.

A ambivalência de sentimentos despertados pela cidade e pelo campo também "predispuseram-no a apreender em profundidade o sentido psíquico e moral do destino do homem moderno" (MERQUIOR, 1975c, p. 244), tal com o entende Benjamin. Merquior então propõe aqui uma interpretação sociológica e psicanalítica, não de modo a organizar seu texto, mas em passagens pontuais como, por exemplo, a partir da associação que faz entre certo telurismo na obra do poeta e "motivos edipianos": "O individualismo narcisista, prolongando vários traços da libido infantil, parece ter sido a forma típica de sublimação engendrada no Brasil pela repressividade do regime patriarcal.” (MERQUIOR, 1975c, p.206).

Fica assim evidente o compartilhamento de Merquior com Schwarz da ideia da literatura como representação das contradições sociais pretensamente nacionais estabelecidas pela sociologia. Aí talvez esteja também a diferença fundamental entre seu trabalho e o de Schwarz, já que enquanto Merquior emprega a sociologia de modo difuso e num processo de ordenação e classificação dos poemas e livros de uma obra, não só Schwarz a privilegia como referência fundamental de sua leitura alegórica, como a literatura é instrumento para a construção de uma hipótese sociológica. Sendo essa diferença relativa à ênfase dada à leitura

\footnotetext{
${ }^{31}$ Merquior afirma que "o conteúdo sociológico do lirismo drummondiano é tanto mais rico pelo fato de sua aventura pessoal - o filho de fazendeiro tornado burocrata na grande cidade - coincidir com a evolução social do Brasil" (MERQUIOR, 1975c, p.48, grifo do autor)
} 
alegórica voltada para preocupações nacionais e não de caráter dessa leitura, já que em ambos os trabalhosa representação é de uma realidade sociológica totalizante e generalizante, ambos os trabalhos são aqueles que, dentro do nosso corpus, mais afirmam a autonomia do ficcional.

Passemos ao estudo de Merquior sobre a obra de Drummond, dividida em quatro fases. A primeira unidade da obra do escritor seria composta por seus três primeiros livros: Alguma poesia (1930), Brejo das almas (1934) e Sentimento do mundo (1940). Esta fase já se ligaria à literatura de vanguarda pelos seguintes procedimentos: a) diversas versificações; b) humor; c) ótica grotesca; d) escrita mesclada ("correlato estilístico da ótica grotesca"), frequentemente ligada à associação surrealista; e) efeito de distanciamento, "concepção nãoempática, antipatética do lirismo" (cf. MERQUIOR, 1975c, p.48). Contudo, essa primeira fase será ainda um tanto neorromântica, oscilando entre um pólo subjetivo, presente no "motivo do gauche", e o pólo objetivo, presente no "motivo da "vida besta" (MERQUIOR, 1975c, p.48). Enquanto o primeiro é individualista e cultiva o evasionismo, o segundo não exclui a solidão, mas denuncia o evasionismo, começando a demonstrar a "ética do engajamento" presente em Sentimento do mundo (1940).

Esse "estilo da juventude" (MERQUIOR, 1975c, p.121) da primeira fase, "poética do vivido" (MERQUIOR, 1975c, p.71), será rompido em José (1942), em um poema como “O lutador", por exemplo, no qual a poesia apareceria como arte do nome do objeto e não arte do objeto, passando a instaurar uma "poética fundada na experiência da linguagem" (MERQUIOR, 1975c, p.72) ${ }^{32}$. Assim, na segunda fase, composta por José (1942) e Rosa do povo (1945), teríamos seu ápice com o anúncio da classicização do modernismo ao trazer, junto com poemas metapoéticos, a poesia voltada para a "interrogação existencial" e para o "realismo social excepcionalmente penetrantes" (MERQUIOR, 1975c, p.121). No caso dos poemas de Drummond dos livros anteriormente citados, o "estilo puro" (ausência da mescla de estilo apontada a seguir) permaneceria moderno, pois se restringiria à técnica, sem ser acompanhado da "idealização da cena lírica" (MERQUIOR, 1975c, p.65) ou da "idealização trágico-sublime" (MERQUIOR, 1975c, p.65), preocupando-se apenas em manter a unidade de estilo, ritmo, tema etc., tal como em "Viagem de família".

Pois bem, o terceiro estilo da obra de Drummond, sua segunda maturidade, é composto dos livros Novos poemas (1948), Claro enigma (1951), Fazendeiro do ar (1953) e A vida passada a limpo (1959). Nessa fase, os temas do cotidiano quase estão ausentes, sendo

\footnotetext{
32 Tomemos um trecho do poema como exemplo: "Lutar com palavras/ parece sem fruto./ Não têm carne e sangue.../ Entretanto, luto. [...] Luto corpo a corpo/ luto todo o tempo,/ sem maior proveito/ que o da caça ao vento./ Não encontro vestes,/ não seguro formas,/ é fluido inimigo/ que me dobra os músculos/ e ri-se das normas/ da boa peleja". (DRUMMOND DE ANDRADE, 2003, p.100-1)
} 
maior a presença do classicismo, dado que "evita a representação social-concreta [...] abandona a ótica sociológico-realista de $A$ rosa do povo em favor de um simbolismo abstrato, refratário à figuração da empiria social” (MERQUIOR, 1975c, p.192). Nesses livros, o poeta realizaria o que Broch chama de estilo da idade mítica, no qual haveria um desprezo pelas "caracterizações individualizantes", engajando-se em uma escrita do pensamento, interrogativa e não confessional. O poeta teria então escolhido "a escrita classicizada como uma estratégia absolutamente legítima [...] para construir uma representação 'mítica' do mundo, isto é, uma figuração poética adequada à reflexão filosófica existencial". (MERQUIOR, 1975c, p.201)

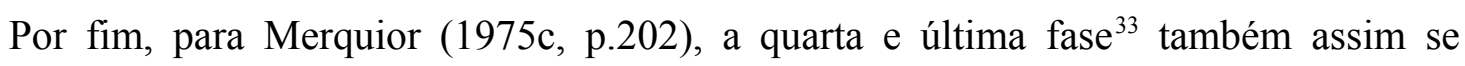
caracteriza e Lição de Coisas (1962) seria marcado por essa reflexão filosófica, mas original em relação aos outros livros da época, pois se desenvolve em quatro direções: "a poesia sobre a poesia (ou metalirismo); a poesia erótica; a poesia do eu; a perplexidade diante da ordem do ser ou do problema do mal”. Esse livro seria marcado pelo estilo mesclado, que sofreria uma espécie de eclipse momentânea em Boitempo (1968) e que é definido como "a resultante da fusão da perspectiva problemática da vida com referências 'vulgares', isto é, a figuração literária das realidades 'baixas', cuja presença foi muito tempo proibida no 'estilo elevado' pela poética clássica" (MERQUIOR, 1975c, p.233). Apenas a "ótica bufa ou gaia" do livro seguinte esmorece o estilo mesclado. A falta que ama (1968) também daria continuidade ao seu desaparecimento, mas pelo motivo oposto, pela continuidade da "presença hegemônica do poema especulativo" ou "lirismo filosófico", ainda que não absoluta (MERQUIOR, 1975c, p.235).

Seu trabalho é aquele que apresenta os operadores de leitura mais próximos daqueles já aceitos pela geração de críticos anteriores, pouco acrescentando ou questionando em relação a eles. Cada fase é descrita pelos livros que a compõem e esses por seus poemas que, em seu conjunto, fazem o caminho inverso e dão sentido aos livros e às fases, pois submetidas a esse modelo dedutivo. Aqui o que temos é fundamentalmente uma obra organizada de maneira dividida em fases que passam pela confirmação nos poemas de classificações estilísticas gerais (estilo classicizante, estilo "mítico", estilo mesclado etc.) a partir do que entende ser o seu tema e traços gerais de sua metrificação. Assim, cada livro de poesia de Drummond costuma contar com os seguintes elementos: número de poemas contidos no livro; ruptura e continuidade em relação ao livro anterior; divisão dos poemas em temas (motivos);

\footnotetext{
${ }^{33}$ Aqui é necessário lembrar que quando Merquior se refere ao tempo presente, 1975 , isso implica que, naquele momento, a obra de Drummond vai até a publicação de Impurezas do branco (1973).
} 
citações comprovando presença dos temas e dos estilos literários; apontamentos sobre divisão rítmica dos poemas; pequena conclusão do comentário sobre o livro.

\section{A perversão do trapezista: o romance em Cornélio Penna}

Antes de passarmos para a análise de $A$ perversão do trapezista: o romance em Cornélio Penna (1976), apontemos o que seria o traço mais evidente da superfície do seu texto e que toca à pretensão à objetividade científica. Em seu trabalho, há uma forte interlocução com os escritos de Northrop Frye, tanto na direção de defender a crítica literária como discurso objetivo como do ponto de vista de uma retórica da possibilidade de defesa da"classificação sistemática":

há um lugar para a classificação na crítica, como em qualquer outra disciplina, que importa mais do que uma realização elegante de alguma casta mandarinesca. A forte repulsa emocional sentida por alguns críticos quanto a qualquer forma de sistematização em Poética é, porém, o resultado em uma falha em distinguir a crítica, como um corpo de conhecimentos, da experiência direta da literatura, na qual cada ato é único e a classificação não tem cabimento. (FRYE, 1957, p.36)

Como Frye, Costa Lima também tenta estigmatizar seu opositor como romântico que vê a teoria e a análise literária como castrações de algum tipo de vivência legítima, primeira, autêntica, etc. da poesia. Contudo, ao invés de se embrenhar em uma teoria literária marcada pela interlocução com a poética clássica, o crítico o fará em relação à obra do antropólogo Lévi-Strauss, objeto de interesse de estudo particular também por parte de Merquior. Como vimos, enquanto o primeiro praticamente não aproveita o trabalho do antropólogo na análise, o segundo se apropria de modo construtivo da sua metodologia e isso aparece na ideia de que o conhecimento sobre a literatura presta contas à tendência à objetividade científica da antropologia de Lévis-Strauss. Em “A análise estrutural em lingüística e antropologia” (1945), publicado posteriormente em Antropologia estrutural (1958), ao falar das relações entre o método de investigação da fonologia e as ciências sociais em geral, o antropólogo se pergunta: "poderiam os sociólogos, utilizando um método análogo quanto à forma, (senão quanto ao conteúdo) ao que é utilizado pela fonologia, levar sua ciência a um progresso análogo ao que acaba de se dar nas ciências lingüísticas?" (LÉVI-STRAUSS, 2004, p.46). Nessa pergunta está pressuposta a ideia de que o método da fonologia pode fundamentar uma ciência social e Costa Lima tenta fazer o mesmo em relação à teoria literária em Estruturalismo e Teoria da Literatura (1973), mas empregando como mediação a tentativa do antropólogo. 
Assim, Costa Lima se apega, na construção de sua análise da obra de Cornélio Penna, fundamentalmente aos desdobramentos que tira de Estruturas elementares do parentesco (1949) e Mitológicas (1964-1971). Façamos um breve comentário de Estruturalismo e Teoria da Literatura (1973) (1970), dado que traz formulações mais explícitas sobre os pressupostos teóricos de sua análise da obra de Cornélio Penna,. O livro, publicação de sua tese de doutorado, é dividido em seis capítulos; enquanto os três primeiros cuidam, respectivamente, de traçar os limites da estética, da estilística e do formalismo russo, os três últimos cuidam de recorrer à antropologia de Lévi-Strauss para pensar uma alternativa teórica que escape às restrições apontadas nos três conjuntos de autores e textos de que se ocupa na primeira parte. Nessa tentativa, Costa Lima repensa a literatura dentro desse horizonte antropológico, animado pela possibilidade do texto literário ser visto como objeto de estudo de modo análogo ao mito e à loucura, não só no sentido de que seriam objetos que resistem ao conhecimento estritamente científico, mas que existem a partir de um fundamento gnosiológico próprio, no caso, a antropologia estrutural e a psicanálise. Faltaria, nesse sentido, um fundamento equivalente para o estudo da literatura e Costa Lima se dedica a constituí-lo e a fundá-lo.

O crítico então retoma o capítulo "A duplicação da representação nas artes da Ásia e da América”, em Antropologia estrutural I - II (1958-1973) e o estudo sobre a pintura facial dos Kadiwéu em "Uma sociedade indígena e seu estilo", capítulo de Tristes trópicos (1955). No caso desta última, Lévi-Strauss aponta recorrências nas pinturas da tribo e diz que apenas a sua "análise estilística" indicaria repetições e equilíbrio. Para ultrapassar isso que seria uma análise apenas descritiva, seria necessário saber qual a função da pintura dentro da organização social da tribo. Ou seja, os desenhos não ganham sentido sem que se saiba qual a sua função e em que contexto simbólico eles existem: "não é só a máscara que mostra sua motivação lógico-social, mas também sua espécie, o desdobramento”. (COSTA LIMA, 1970, p. 307). Nesse sentido, "não apenas o conhecimento do contexto se exerce ao nível do discurso, como, em direção inversa, a indagação do imaginário serve para o conhecimento do social." (COSTA LIMA, 1970, p. 307).

Ao contrário dos trabalhos de Schwarz e Merquior, contudo, há aqui a preocupação em abandonar o termo "representação", empregado pelo que chama de "tradição mimética", presa a uma ideia de literatura como reflexo. O crítico encerra sua tese propondo o termo "representação" e a presença do hífen marcaria a proximidade com a ideia de "des-velação", que o "texto que se oculta sob o texto, a dupla linguagem que aproxima a arte de 'loucura'." (COSTA LIMA, 1970, p.399). Essa dupla linguagem seria fruto de uma ruptura no 
pensamento ocidental, feita por Marx, Freud e Saussure, que implicou na ideia de que tanto sociedade como discurso têm um nível aparente e outro profundo. Os discursos de representação, entre os quais a literatura se incluiria, são todos discursos duplamente articulados, sendo o nível profundo, nesse caso, entendido do ponto de vista de uma estrutura ou sistema e não de "formulações apenas bem inspiradas" que seriam, para o crítico, o caso das estéticas.

Vejamos abaixo o modo como Costa Lima (1970, p.402-3) agrupa, opõe e sintetiza o que constrói como problemática sistêmica e problemática estética, opostas também, respectivamente, pelas ideias de re-presentação e representação:

\begin{tabular}{|l|l|}
\hline Problemática sistêmica & Problemática estética \\
\hline 1) Centrada em invariante. & 1) Centrada no receptor. \\
\hline $\begin{array}{l}\text { 2) Leitura de dominância } \\
\text { paradigmática. }\end{array}$ & $\begin{array}{l}\text { 2) Leitura de } \\
\text { dominância/exclusividade } \\
\text { sintagmática. }\end{array}$ \\
\hline $\begin{array}{l}\text { 3) Função da exploração do } \\
\text { significante. }\end{array}$ & $\begin{array}{l}\text { 3) Função de um efeito de } \\
\text { deslocamento. }\end{array}$ \\
\hline $\begin{array}{l}\text { 4) Supõe a autonomia da lógica do } \\
\text { inconsciente. }\end{array}$ & $\begin{array}{l}\text { 4) Supõe que o discurso é função } \\
\text { do inconsciente. }\end{array}$ \\
\hline $\begin{array}{l}\text { 5) Supõe a linguagem ser produto de } \\
\text { articulação interna (sintagmática }+ \\
\text { paradigmática) e externa (linguagem } \\
\text { versus silêncio). }\end{array}$ & $\begin{array}{l}\text { 5) Supõe que a linguagem } \\
\text { equivale à presença do dito } \\
\text { (enunciado). }\end{array}$ \\
\hline
\end{tabular}

Ora, o registro em que distingue a problemática sistêmica da problemática estética está preso a um paradigma científico, mas não do ponto de vista da ciência econômica, como em Schwarz, mas da legitimidade epistemológica que a psicanálise, a linguística e a antropologia ganharam ao longo do século XX. Costa Lima parte do suposto de que da mesma forma que é possível identificar uma estrutura fonológica exercida de modo inconsciente pelo falante, no texto literário há uma espécie de "enigma", de solução a ser construída como uma estrutura a partir da interação do nível sintagmático com o paradigmático.

Vejamos que, dos trabalhos de nosso corpus, aqueles assinados por Costa Lima são os mais evidentemente defensores do objetivismo científico. O crítico chega a afirmar que "as análises estéticas divergem não por conta da riqueza inevitável do texto, mas pelo tipo de leitura adotada, pois esta impede a aplicação de critérios de verificabilidade." (COSTA LIMA, 1970, p.401, grifo nosso). Centradas na experiência do receptor, na fruição, as estéticas manteriam o desconhecimento do texto literário cujo entendimento só seria permitido pela ultrapassagem do que está no seu nível sintagmático em direção ao paradigmático. Negar isso seria manter o registro da "auto-leitura" (COSTA LIMA, 1970, p.401), mero investimento dos próprios valores literários do crítico. Apenas a análise sistêmica de caráter estrutural permitiria a fuga da subjetividade ou de uma objetividade 
aparente (cf. COSTA LIMA, 1970, p.401). Ou seja, para Costa Lima (1970, p.62) existe uma "objetividade real" que, ainda que se preste a análises infinitas, o que para ele seria "nosso malogro", permite que "a linguagem não-conceitual da literatura não [impeça] a sua conceitualização, ou seja, a objetividade do que acerca dela se escreva." Ainda que Costa Lima (1970, p.62) faça ponderações em relação à objetividade científica, ao dizer que a teoria que propõe permite "o máximo de questões formuláveis" a partir do sintagma, e não a totalidade delas, senão seria científica. Sua ponderação, no entanto, não resiste ao próprio modo de exposição dessa passagem em um complexo diagrama de círculos e triângulos que reafirmam a tendência à valorização da objetividade científica.

O sistema montado por Costa Lima se justifica a partir da análise dos mitos de LéviStrauss, e o que este via como conjunto de variantes e versões de um mito, aquele verá como o conjunto de romances agrupados sob a mesma assinatura e estilo, sendo estes dois últimos uma unidade ${ }^{34}$. Assim, há em A perversão do trapezista (1976) uma divisão em duas sessões. Na primeira, ele se atém aos romances de Cornélio Penna: Fronteira (1935), Dois romances de Nico Horta (1939) e Repouso (1948) seriam variantes fracas, nas quais algumas relações matriciais estão ausentes, contemplando apenas parcialmente os elementos organizadores dos romances; e na segunda, ele se atém à variante forte, o romance $A$ menina morta (1954), em que todas as relações matriciais estão presentes.

Sendo A menina morta (1954) um romance menos conhecido e crucial para a argumentação do crítico, retomemos brevemente seu argumento principal para que se possa acompanhá-la. O romance se passa no fim do século XIX em uma fazenda decadente chamada Grotão, habitada pelo proprietário Comendador, que pouco permanece lá, e por sua esposa Mariana; por Virgínia, prima do Comendador; por Celestina, prima de Mariana e pelos escravos. O romance começa com a morte recente da segunda filha do casal, a quem o narrador se refere como Menina Morta, e Carlota, a primogênita, que é trazida da corte para a fazenda. Esta passa a integrar um cotidiano de silêncios e segredos nunca rompidos ou revelados, no qual as ações se arrastam em um tempo marcado por longas descrições e digressões.

\footnotetext{
${ }^{34}$ Vejamos como o crítico problematiza essa unidade: "será o caso de perguntar se todos os textos de um autor serão variantes. No estágio presente de nossa pesquisa, não é possível uma resposta conclusiva. [...] Diremos, porém, que, a princípio, essa é a tendência, porquanto o aparelho psíquico individual tem um grau de recorrência que o leva a operar com uma mesma matriz. Isso, entretanto, não significará que a teoria afirme todas as obras de um autor se repetirem internamente. Uma matriz é tanto mais rica quanto mais variadas sejam as 'frases' que permitam compor. Nem todas essas 'frases' terão a mesma correspondência com a matriz. Aquelas, cujo exame nos permite extrair a totalidade das articulações matriciais, chamamos, com Lévi-Strauss, variante forte. Quando, ao contrário, a 'frase' não nos permite visualizar senão uma parcela matricial, deixando vazios os lugares de outras relações - lugares conhecidos a partir da variante forte -, a chamamos de variante fraca." (COSTA LIMA, 1976, p.60)
} 
Nesse romance, os personagens seriam então movidos por formas fracas e fortes de interdição, sendo as primeiras relativas ao toque corporal e as segundas à "troca de palavras que não sejam ficcionais" (COSTA LIMA, 1976, p.115), ambas em um presente de ausências habitado por fantasmas suspensos entre uma "fantasia do passado e o horror do futuro [...] O passado é matéria de fábula. $\mathrm{O}$ futuro, em troca, se confunde com a expectativa de cegueira, paralisia, loucura senil [...], é ansiado como a hora em que se realizará a fuga definitiva". (COSTA LIMA, 1976, p.124-5). Essa suspensão no tempo é movida pelo que o autor chega a chamar de "indigência dos contatos", já que o interdito verbal é geral (ainda que hierarquizado), impossibilidade total de comunicação no presente e que reúne as palavras em forma de lembrança e de sonho, nos levando à "presença dos fantasmas e dos enigmas" (COSTA LIMA, 1976, cf. p.115). Ora, a essas duas formas de interdição, do toque corporal e da fala, se juntam duas modalidades de interdição. A primeira é aquela em que os agentes são ativos, na maior parte do tempo; a segunda é quando ela independe da vontade dos personagens, como a cena em que Carlota, ao decifrar o enigma da irmã morta, vai contá-lo às escravas. Estas, ao acharem que a ansiedade da senhora seria seguida de repreensão, antecipam-se em chorar copiosamente e a impedem de contar. Assim é que os silêncios ultrapassam a relação entre as classes e se hierarquizam de tal forma que o significante flutuante $^{35}$, aqui, tem uma possibilidade de significado legalizado, a menina morta, ou é “expressão de enigmas" na superfície dos textos (COSTA LIMA, 1976, p.117, grifo nosso).

Essas formas e modalidades de interdição caminhariam com uma lógica de alternância entre o masculino (traço vampiresco) e o feminino (traço fantasmagórico ${ }^{36}$ ). No caso do primeiro, o Comendador é identificado como vampiro, os escravos como vampirizados e Virgínia, Rola e Inacinha, representantes do vampiro e integrantes desse lado simbolicamente

\footnotetext{
${ }^{35}$ O termo "significado flutuante" está presente na "Introdução à obra de Marcel Mauss" (2003), publicado em 1950, por Lévi-Strauss, e aparece como forma de interlocução com Durkheim e sua reflexão em torno da noção de "maná", fruto do que seria, para o antropólogo, um esforço de transcender a empiria e fazer do fenômeno social um sistema. Ele seria um "valor simbólico zero, isto é, um signo que marca a necessidade de um conteúdo simbólico suplementar àquele que pesa já sobre o significado, mas que pode ser um valor qualquer, com a condição de fazer parte ainda da reserva disponível e de já não ser, como dizem os fonólogos, um termo de grupo" (LÉVI-STRAUSS, 2003, p.19). Ora, esta noção de maná seria fundamento de juízos sintéticos a priori, mas não ligada à expressão de "noções de sentimento, fatalidade, de fortuito e de arbitrário" (Ibidem, p.17). Tal como defendia Durkheim, elas deveriam ser noções científicas, ligadas ao papel que desempenham em um sistema. Neste outro registro, Lévi-Strauss propõe a ideia de "significante flutuante, que é a servidão de todo pensamento finito (mas também a garantia de toda arte, toda poesia, toda invenção mítica e estética), embora o conhecimento científico seja capaz, senão de estancá-lo, ao menos de discipliná-lo parcialmente.” (Ibidem, p.19)

${ }^{36}$ Ao nos referirmos a um "traço fantasmagórico" estamos tratando do que o crítico chamou de "modo fantasmal", diferente do que denomina "clima fantasmal": "Temos ocasião, de passagem, de melhor esclarecer a contigüidade entre clima fantasmal e modo fantasmal. A 'nota fantástica' é a base material de que resultam o clima e o modo fantásticos, diferenciados contudo porque o primeiro remete aos perseguidores e o segundo, aos perseguidos, que, ademais, combinam as propriedades de serem do alto (social), de serem sexualmente femininos e em busca doutro sagrado." (COSTA LIMA, 1976, p.144)
} 
masculino dos personagens. Todos eles integram uma relação na qual o eixo está no culto à Menina Morta e convivem com a ordem do feminino, composta por esta última, Mariana, Carlota e Celestina, todas marcadas, com exceção da última, pela "fuga, loucura ou morte". As ordens masculina e feminina se complementam e se revezam. Se num primeiro momento as relações vampirescas dão a tônica de tempos áureos da fazenda, num segundo momento são as fantasmagóricas que acabam por libertar os escravos, auge da degradação da fazenda como unidade produtiva e simbólica.

Haveria assim o caminho feminino, rumo à lareira, lugar de culto da Menina Morta; e o masculino, rumo à corte, à vila, realizado principalmente pelo Comendador. Este último cumpriria uma função central na figura de interditor, com direito a delegações, mas cuja "vigilância do olhar não tem êxito quando o vigiado é capaz de criar para si um outro lugar, suspenso no tempo" (COSTA LIMA, 1976, p.118, grifo nosso), o lugar de fantasma, do louco ou daquele que busca decifrar o enigma.

Nesse sentido, apesar do esforço de construção de um nível paradigmático autossustentado no texto, Costa Lima amarra sua análise de modo a resvalar num entendimento da literatura como representação, no caso de uma visão antropológica e psicanalítica da suposta unidade "cultura brasileira". O que era central no trabalho de Schwarz, difuso no de Merquior, aqui escapa, como veremos ocorrer nos de Silviano Santiago e Portella. Isso demonstra, a nosso ver, que a força não só da presença desse entendimento, como a preocupação com a utilidade da literatura e da análise literária, ou seja, tem função de instrumento para o conhecimento das contradições sociais nacionais.

Cornélio Penna faz narrativas míticas que coexistem com as narrativas romanescas, sendo o tempo uma distinção fundamental entre elas. Se no caso das primeiras o tempo é acumulativo, no caso das segundas, para Costa Lima (1976, p192), há uma "suspensão do tempo" que teme o "acontecimento transtornador" e cuja suspensão "conduz a uma mais entranhada percepção da realidade cultural brasileira." Ora, a "realidade cultural" aqui também será construída com categorias que se insinuam como de longa duração, como a de "ideias fora do lugar", mas com conceitos tirados dessa análise sistêmica dos textos, como os de fantasmas, malandros, demônios, vampiros etc., metáforas de formas de relações sociais que só têm relevância porque pressupõem estudos sobre a unidade produtiva "casa grande", interessados particularmente na dimensão dos espaços privados e das relações afetivas, tal como Casa grande e senzala (1933), de Gilberto Freire, e que permitiram pensar formas de relações sociais de longa duração, como a relação entre senhor e escravo, senhor e mulheres, mulheres e escravos, mulheres entre si etc. Também aqui há uma preocupação em interpretar 
a cultura nacional, concebendo-a como unidade com qualidades essenciais, no caso, uma espécie de conservadorismo e imobilismo deste tempo comandado pelo autoritarismo e pelo silêncio.

\section{Carlos Drummond de Andrade}

Pois bem, notemos que as análises de Merquior e Silviano Santiago constroem uma visão panorâmica da obra de Drummond e estabelecem, entre esta e a vida do autor, uma série de paralelismos, mais ou menos sutis e organizados em uma linha evolutiva que, como veremos no capítulo seguinte, não caminha para melhor no que toca o valor literário. Isso se dá porque, se no caso do primeiro a unidade da obra de Drummond deve ser construída para atender preocupações classificatórias, no caso do segundo ela será mantida para que funcione como termo de uma relação de analogia, como veremos, entre poesia e fala sujeita à análise psicanalítica. Como se nota, apesar do compartilhamento da categoria de obra, entendida nessa chave historiográfica romântica, e da escolha da assinatura Carlos Drummond de Andrade, tudo o mais distingue esses trabalhos, mostrando que o tema de uma análise literária, a princípio, pouco diz sobre ela isoladamente, ainda que tenha mais relevância, como examinaremos, no âmbito do valor literário. Isso se dá porque, como pudemos perceber, junto com o trabalho de Roberto Schwarz, o de Merquior apresenta uma compreensão da literatura como representação sem o questionamento da relação entre esta e a realidade da qual, apesar de se dizer imanente, está apartada pois é assim concebida.

Ora, é justamente essa oposição entre os termos literatura e sociedade/ realidade que os trabalhos de Costa Lima, Silviano Santiago e Portella, cada um a seu modo, vão se engajar em romper. Vimos, no caso do trabalho de Costa Lima, que o sentido do termo representação como representação da realidade escapa, mas que ele demonstra um esforço teórico e analítico fundamental ao propor o termo re-presentação. No caso do trabalho de Silviano Santiago, o mesmo se dá. Contudo, enquanto naquele há uma separação entre teoria e análise literária pressuposta na publicação à parte de Estruturalismo e Teoria da Literatura (1973), seguida de Metamorfoses do silêncio (1974) e de A perversão do trapezista (1976), aqui o esforço de teorização se dá junto com a análise. Daí que a discussão do termo re-presentação aparece só pontualmente isolada e não pode ser separada da análise.

Apesar de suas tentativas serem diferentes, principalmente no que toca a escolha de modelos não literários de análise, já que privilegiam a antropologia e a psicanálise, também aqui escapa a ideia de literatura como representação das contradições sociais. Antes de 
apontar esse resvalo, vejamos o poema "Infância", do livro de estreia Alguma Poesia (1930), estratégico para a construção da sua leitura do que seria a escritura de Drummond:

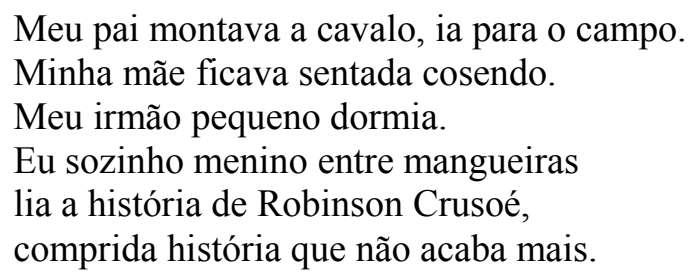

No meio-dia branco de luz uma voz que aprendeu a ninar nos longes da senzala - e nunca se esqueceu chamava para o café.

Café preto que nem a preta velha

café gostoso

café bom.

Minha mãe ficava sentada cosendo olhando para mim:

- Psiu... Não acorde o menino.

Para o berço onde pousou um mosquito.

E dava um suspiro... que fundo!

Lá longe meu pai campeava no mato sem fim da fazenda.

E eu não sabia que minha história era mais bonita que a de Robinson Crusoé." (DRUMMOND DE ANDRADE, 2003, p.6)

Apenas os trabalhos de Silviano Santiago e Portella, em nosso corpus, constroem uma linguagem fundamentalmente não cartesiana, operando com conceitos fluidos, imagens, repetições, percursos não lineares, não conclusivos etc. Contudo, eles se diferenciam e muito em suas compreensões do literário, pois enquanto Silviano Santiago fará essa ruptura, principalmente, via Barthes, Portella a fará por meio do seu emprego bem particular dos conceitos heideggerianos. Como o próprio crítico aponta, e concordamos com ele, ele emprega "procedimento de metonimização e metaforização" (SANTIAGO, 1976, p.87), no qual opera, por exemplo, com vocabulários analíticos construídos a partir do próprio poema, no caso, como os de "vida-em-família", "ilha-da-leitura", "ilha-da-escritura", "leitura-quefaz", "aventura-que-vive-na-leitura", "momento-que-vive”, “outro-da-leitura", "espaçoexclusão", "figura-de-negro", "lugar-do-prazer”. (SANTIAGO, 1976, p53-58)

Pois bem, o poema "Infância", assim como os outros, será lido fundamentalmente a partir da análise do eu lírico. É este que garante, por meio de uma operação de analogia com um sujeito empírico, que o poema seja lido como fala a ser analisada pela psicanálise. Assim, empregando as reflexões de Lacan e Derrida, principalmente o segundo - bem como recorrendo a outros poemas do autor e textos de prosa como "Vila da utopia", de Confissões 
de Minas (1944), ou "Divagações sobre as ilhas", de Passeios na ilha (1952) -, Silviano Santiago lerá o poema identificando não só um sujeito projetado nele como o que seria a própria constituição desse sujeito.

Assim, referindo-se à primeira estrofe do poema, a história de Robson Crusoé é colocada como espaço de exclusão em que se realizaria aquilo que está interdito no espaço da família. Essa exclusão, por sua vez, também é uma "área de inclusão" dada por um processo de transferência para o "outro-da-leitura", sendo a leitura a atividade compensadora da solidão e da ignorância, o "outro especular" (SANTIAGO, 1976, p.50). Contudo, na segunda estrofe, o eu lírico é chamado para "uma realidade, que se diferencia" (SANTIAGO, 1976, p.53), já que

o Sexta-feira do menino é esta preta velha que lhe oferece café preto no meio-dia branco [...] Tentar delimitar as fronteiras entre a realidade do Livro (Sexta-feira) e a do menino (preta velha) é ridículo, pois o poeta quis que se orquestrassem num mesmo contexto, onde o branco se encontra contaminado pelo negro, onde o negro (a escritura e/ou a preta) explicita a mensagem do branco. (SANTIAGO, 1976, p.53-54)

O chamado da preta velha também é um "espaço-de-exclusão", mas nele seria gerado um sensualismo (cf. SANTIAGO, 1976, p.81). Segundo o crítico, apesar de ser difícil não apontar em "Iniciação amorosa", de Alguma poesia, "a associação entre pecado, negro e prazer sexual" (SANTIAGO, 1976, p.65), seria apenas em Boitempo \& A falta que ama (1968) e Menino Antigo - Boitempo II (1973) que se dá realmente a oscilação então entre a sede de prazer e o martírio, entre o "ato proibido pelo decoro familiar" e o "olhar curioso do jovem" (SANTIAGO, 1976, p.68, grifo do autor).

Nesses livros, a criança vê no imaginário alheio, no caso, ligado aos descendentes de escravos, a força de sua existência (no sentido nietzschiano de desejo de dar significado a algo). Neles encontraríamos versos, respectivamente, como os de "Tentativa", "Uma negrinha não apetecível/ é tudo quanto tenho a meu alcance/ para provar o primeiro gosto/ da primeira mulher [...] Em meio à indiferença dos repolhos,/ das formigas que seguem seu trabalho,/ eis que a montanha/ de longe nos reprova/ toda ferro." (DRUMMOND DE ANDRADE, 2003, p.998); ou do poema "Engate”, “O morto no sobrado/ no porão a mulata/ a pausa no velório/ o beijo no escurinho/ a pressa de engatar/ o sentido da morte/ na cor de teu desejo/ que clareia o porão.// O morto nem ligando.” (DRUMMOND DE ANDRADE, 2003, p.1129)

No caso deste último, o crítico opõe essa imagem do porão a de "Le voyeur": "No úmido porão, terra batida/ lar de escorpiões,/ procura-se a greta entre as tábuas/ do soalho/ por onde surpreenda a florescência/ do corpo das mulheres/ na sombra de vestidos refolhados/ que cobrem até os pés/ a escultura cifrada." (DRUMMOND DE ANDRADE, 2003, p.996) Tanto 
neste poema como em "As pernas" e outros haveria um índice de frustração sexual juvenil, uma relação de verticalidade entre o sujeito que deseja e o objeto desejado, de modo que nisso se poderia ver uma "semente de espiritualização que, nas constantes germinações, proclamará o espaço familiar, o sobrado, como o lugar onde também pode se colocar o objeto de desejo." (SANTIAGO, 1976, p.70, grifo do autor). Essa semente da espiritualização se realizaria plenamente em "Castidade" e "Sombra das moças em flor", poemas que integram Brejo das almas (1934), nos quais teríamos a presença de "fantasmas noturnos e angelicais" (SANTIAGO, 1976, p.71), dessa espiritualização que liga a "problemática erótica" àquela relativa à divisão moral entre bem e mal. Vejamos as estrofes abaixo do poema "Castidade":

$$
\begin{aligned}
& \text { O perdido caminho, a perdida estrela } \\
& \text { que ficou lá longe, que ficou no alto, } \\
& \text { surgiu novamente, brilhou novamente } \\
& \text { como o caminho único, a solitária estrela. }
\end{aligned}
$$

Não me arrependo do pecado triste que sujou minha carne, suja toda carne. O caminho é tão claro, a estrela tão larga, os dois brilham tanto que me apago neles. (DRUMMOND DE ANDRADE, 2003, p.62)

Ora, haveria na poesia de juventude de Drummond, um recalque do "sensualismo" ao qual nos referimos anteriormente e do qual sua poesia madura quer se livrar. Com base em uma moral asceta, esta última seria marcada por deixar ir para a superfície do texto apenas os problemas do conhecimento, de modo geral, destituído de sexualidade, do corpo. Essa mudança de tema seria lida pelo crítico como "aceitação dos valores familiares" (SANTIAGO, 1976, p.81), dado o abandono do espaço-de-exclusão e da individualidade em prol dos valores do clã, da família, da comunidade. A idade madura se oporia ao sensualismo do menino, deixando-o quando adulto à “"sombra' do pai que deixa a criança inteiramente à margem de si mesma, 'protegida' de toda a liberdade que lhe tinha propiciado a criação dos valores da moral robinsoniana" (SANTIAGO, 1976, p.91).

Segundo o crítico, num poema como "Infância", o conhecimento se faz pela mediação da ficção, nos poemas da maturidade, ele se dá pela mediação do texto documentário. Segundo Silviano Santiago (1976, p.94), o eu lírico maduro, maturidade entendida dentro desse tempo da escritura, relaciona-se com "seres-de-papel", "figuras re-presentadas da família" na qual só pode haver "silêncio e vontade de comunicação", dado que "é o ser escrito que se apresenta apenas no presente da representação, isto é, já é sempre em posteridade" (grifo do autor). Posteridade aqui entendida como a coloca Freud, relativa ao poder de cura que tem a mudança do olhar para o passado. A obra do poeta caminharia para uma identificação entre o "outro (filho)" e o "mesmo (pai)" (SANTIAGO, 1976, p.96), entre filho 
e Lei que culminaria na ocupação do lugar vazio, deixado para o eu lírico, na mesa da família no poema "Comunhão", em A falta que ama (1968): "Todos os meus mortos estavam de pé, em círculo / eu no centro [...] Notei um lugar vazio na roda. / Lentamente fui ocupá-lo. / Surgiram todos os rostos, iluminados" (DRUMOND DE ANDRADE, 2003, p.688).

Este percurso é entendido por Silviano Santiago (1976, p,101-2) como perda da "moral de revolta de Passeios da ilha" e adia-se ao máximo a tomada de consciência da luta entre pai e filho, querendo se livrar da escritura como se a origem pudesse ser individualmente dada. Como no caso do poema "Infância", aqui caberia lembrar o poema "Escritório":

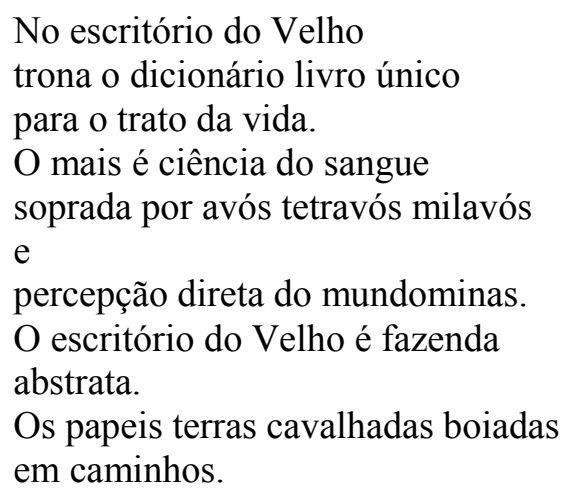

Antes de analisar esse poema, Silviano Santiago se detém principalmente nas partes do livro Lição de coisas (1962): “Origem", que contém o poema "A palavra e a terra", e "Memória". A partir delas, o crítico discute os conceitos de linguagem, terra e sangue, “enquanto participantes de uma problemática filosófica” (SANTIAGO, 1976, p. 109), vistos como termos da relação de alienação e separação descritos por Lacan entre o eu e o grande outro, entendido como cadeia de significante. A linguagem é, como o sangue, bem simbólico pedido de empréstimo ao pai, identificado também com a metáfora da terra. Para existir, o poema

tem de matar o Pai que o escreve e, sendo proposta paralela à terra, pois é a terra em re-presentação (em linguagem, em signos), como escritura a anula. [...] Na cena do poema, representa-se o drama da origem, drama, como estamos vendo, sem a "presença" do Poeta, cujo personagem mais constante no entanto é a máscara-do-poeta, ou seja, o poeta enquanto gerado, enquanto sendo gerado pela re-presentação de seu próprio drama. (SANTIAGO, 1976, p. 106) 
Nesse sentido, o poema "Escritório", publicado em Boitempo (1968) e citado acima, será tomado como espécie de síntese em que linguagem, terra e sangue são codificados e descodificados de modo que o Pai aqui se torna presente na forma, respectivamente, de dicionário, documento e moeda. Como escritura, funda um tempo e um espaço homogêneo onde essas três formas de ciência podem coexistir: a escritura do dicionário, usada para o trato da vida; a escritura do Pai, fonte da "ciência do sangue"; a escritura do mundo, fonte dos “conhecimentos universais" (SANTIAGO, 1976, p. 112-3). Através desses elementos se pode conhecer “em livro aberto o Real” (SANTIAGO, 1976, p.109), no caso, a plurissignificação de um Real empírico.

Para Silviano Santiago (1976, p.93), Drummond, antes de mais nada, é simultaneamente um poeta da escritura e da re-presentação:

o texto Drummondiano dramatiza, em sua essência, a verdade paradoxal de que jamais se conhece o momento presente do Real; todo o conhecimento do presente do Real se faz a posteriori, pelo desvio da re-presentação, pela mediação ou do texto de ficcão ou do texto documentário. (SANTIAGO, 1976, p. 93)

O crítico adota assim uma postura nominalista, na medida em que o poema se refere a outros termos do imaginário que ele vai constituindo em metáforas que cria a partir de suas imagens num ciclo autorreferente, em que se chega ao real empírico pelo real re-presentado. (cf. SANTIAGO, 1976, p.83)

Ora, vejamos que escapa ao crítico, mesmo em sua formulação teórica, uma ideia de representação, dado que deve haver um "Real empírico" que garanta a mediação necessária para a historicidade do poema. Notemos que, como no trabalho de Costa Lima, apesar do enorme esforço de afirmação de uma ideia de re-presentação, aqui também o crítico resvala numa ideia tradicional de representação das contradições sociais. No caso em questão, elas são semelhantes àquelas apontadas por Silviano Santiago, sendo que aqui a unidade produtiva "fazenda" interessa mais como lugar de conjunção de imaginários culturais e circulação do desejo; enquanto no caso do trabalho de Costa Lima, ela era lugar de imposição, sujeição e transgressão das diferentes formas de presença do patriarca e de seu poder de castração. De todo modo, se lá a suspensão do tempo é um traço cultural nacional, aqui, apesar de não explicitada, a ênfase ao recalque do sensualismo na poesia de juventude institui claramente imagens, passagens e supostos temas dos poemas como representações diretas de um recalque que poderia ser generalizado, numa sociedade com forte presença da uma herança escravocrata, qual seja, o do desejo do homem branco pela mulher negra.

\section{Fundamentos da investigação literária}


Dissemos que Silviano Santiago e Portella assinam os únicos trabalhos cujas escritas são preocupadas em fugir de uma retórica dissertativa que preza pela definição dos conceitos e por sua sistematicidade. Contudo, enquanto no caso do primeiro, como vimos, trata-se um "procedimento de metonimização e metaforização" (SANTIAGO, 1976, p.87), no caso do segundo, há, em Fundamentos da investigação literária (1974), uma "estratégia circular mediante a qual, em cada momento, se retoma os demais momentos" (PORTELLA, 1974, p.17), dado que é estruturado de modo a percorrer diferentes dimensões do que seria a constituição ontológica do acontecimento literário.

A primeira parte de sua investigação é relativa ao conhecimento científico e é abordada no capítulo "Opção científica do conhecimento e peculiaridade do fenômeno literário", capítulo que, não à toa, ocupa um terço do livro. Como dissemos anteriormente, nessa época, os modos de compreensão marcados pela heteronomia do literário passavam, como vimos, pela afirmação de modelos não literários de leitura, como o demonstra, entre outras coisas, o modo como se deu a intertextualidade com a economia, a sociologia e a antropologia estrutural de Lévis-Strauss. Portella, cujo trabalho é aquele que mais afirma a autonomia do ficcional dentro do nosso corpus, diagnostica a recusa a essa compreensão: “a ciência é agora expansão da verdade, na sua última instância. Como então pesar a literariedade sem ser em tensão com a cientificidade?” (PORTELLA, 1974, p.22). Portella preocupa-se em distinguir sua perspectiva tanto de uma teoria da história dialética, como da hermenêutica de Dilthey, mas trazendo de ambas a conciliação entre ciência e estudos históricos da literatura e da arte, conciliação na qual:

nós estamos movendo no território da hermenêutica, onde a preocupação ontológica se sobrepõe a qualquer veleidade epistemológica [...] Enquanto o discurso gnoseológico se processa no nível da ciência, a hermenêutica se articula como uma ontologia e, no caso, uma ontologia da linguagem. [...] o que se pretende com uma ontologia da linguagem? A resposta é uma só: desvelar a ideologia do dis-curso, descrever a tensão do entre-texto. (PORTELLA, 1974, p.24)

Além do que seria a ausência de uma historicidade dos textos literários, na qual nos deteremos a seguir, vejamos que o procedimento de demonstração da hipótese analítica nos textos literários, que antes era valorizado (dada a tendência existente de uma lógica de comprovação), agora deixa de ter qualquer valor dentro dessa perspectiva.. No pólo oposto da tendência à objetividade científica, o crítico propõe um modelo de leitura, que chama de "trans-modelo", que fugiria de uma lógica quantitativa e acumulativa de dados, de uma "semântica dos fatos" (PORTELLA, 1974, p.109) na qual a compreensão de um texto deve se 
ater ao que nele está escrito e deve ser compartimentado, somado, computado etc. Essa leitura focada na qualidade se fixaria àquilo que tem transcendência em relação aos fatos, mas que, ao mesmo tempo, os gera, sendo em relação a eles presente, ausência, potência.

A passagem acima indica o que Portella prioritariamente almeja com seu trabalho, qual seja, a construção do fundamento de uma compreensão do texto literário, voltado para a preocupação ontológica, relativa ao ser, tal como em seu entendimento heideggeriano. $\mathrm{O}$ crítico então define o bom texto literário, ao qual se refere como texto literário de modo geral, como entre-texto, sempre em tensão com o texto e o pré-texto. A partir da divisão que Heidegger propõe entre ente e ser, em sua busca por fundamentos da investigação literária, o crítico propõe as divisões entre pré-texto, texto e entre-texto e entre língua e linguagem. No caso da primeira, o pré-texto (história, sociedade, costumes, etc.) é que se transforma em entre-texto, ou seja, em boa literatura, através da linguagem. O texto, por sua vez, está na dimensão do fato, do acontecimento, da organização dos elementos presentes como vocábulos, expressões, métrica, sintaxe etc.

Vejamos que aqui teremos um procedimento semelhante ao de Silviano Santiago, na medida em que o sentido do texto literário (entre-texto, como veremos) é deduzido a partir de sua identificação com a definição que o crítico constrói dentro de uma relação de analogia entre ficção e fala a ser analisada; e ficção e ente. Em ambos os casos, o modelo de análise é não literário, mas não tende a valorizar a objetividade científica. No entanto, apesar das semelhanças, do ponto de vista do conhecimento, o trabalho se Silviano Santiago ainda está menos distante por ter a psicanálise, ou seja, uma epistemologia como principal referência. Já Portella, sem essa mediação de uma epistemologia, mas apoiado numa fenomenologia da literatura de lastro heideggeriano, parece romper de modo mais profundo com a exigência de determinação do objeto literário nesse registro. No caso do primeiro, a ideia de imaginário, entre outras coisas, pretende realizar a união entre literatura e realidade; aqui, a relação é imediata, e o que veremos chamar de pré-texto pouco aparece em sua análise, assim como o problema da "realidade ficcional", vamos dizer assim.

Já no caso da segunda divisão, para Portella (1974, p.80-1), a língua é vista como "conjunto dos signos do dizer, sintaxe e armazém vocabular", dentro de um sistema é "representação da coisa" e o integra como função combinatória, apenas texto, signos cuja verdade aparece em sua estruturação do Signo, degradação da Verdade originária (PORTELLA, 1974, p.71). Já a linguagem é objeto da crítica totalizante, pois é “estrutura geradora de signos, Signo" (“operação da verdade do real” (PORTELLA, 1974, p.73)), Ser do homem, "pré” do texto, "força estruturante", “poder instaurador" (PORTELLA, 1974, p.74), 
força do que se diz atuando e implantando sistemas de signos só se encontram em "criações globais", ou seja, em grandes obras.

Em Fundamentos da investigação literária (1974), temos então a análise de textos literários que permitem a sua leitura qualitativa. Esta última se dá de modo absolutamente pontual ao longo de dez páginas de análise de trechos de "Navio negreiro" de Castro Alves, “Buriti”, de Guimarães Rosa e Uma aprendizagem ou o livro dos prazeres (1969), de Clarice Lispector. Apesar de breves, elas servem de exemplo de entre-textos nos quais a língua recebe "carga nova da sobredeterminação", aqui entendida como "abertura da totalidade", "concreto universal" (PORTELLA, 1974, p.77). O conceito de sobredeterminação serve de mediação entre sujeito e sociedade, no qual ambos seriam "processo de estruturação" que se alimenta dessa "infiltração sobredeterminante" que a todo instante pode voltar a reinstaurar o próprio sistema:

segundo Althusser, foi a incontrolável avalanche sobredeterminante que detonou o processo revolucionário na União soviética [...] No caso da poesia abolicionista de Castro Alves, a sobredeterminação foi capaz de mobilizar ou dinamizar, em diferentes níveis, o que fora estagnado pelo sistema de oposições escravocrata. (PORTELLA, 1974, p.76-77).

Os textos analisados por Portella, nesse sentido, dão forma e instituem um porvir em diversos âmbitos. Seja o combate à escravidão, em "Navio Negreiro", ou a subversão da gramática, em "Buriti" e Uma aprendizagem ou o livro dos prazeres (1969). O estilo é necessariamente a união do passado, presente e futuro. Assim, se a língua é o que está no âmbito do texto, do dito, então ela é objetivável, e esta é sua grande diferença em relação à linguagem que, por sua vez, não se esgota em nenhuma objetivação. Podemos perceber então que a concepção de linguagem presente nesse trabalho do crítico é da ordem do incondicionado. Como exemplo, poderíamos dar a passagem em que, ao falar do poema de Castro Alves o crítico ressalta a diferença entre o escravo empírico, como língua e o escravo como linguagem:

acentua-se cada vez mais, a caracterização implacável do mundo escravocrata. Os filhos do deserto não são escravos. O africano é linguagem, desde que manifestação livre do real. Arrancado de sua condição é quando torna-se língua. O poeta desmonta, no interior da experiência poética, a "ideologia da submissão". (PORTELLA, 1974, p.92)

O termo "filhos do deserto" se refere ao seguinte trecho do poema:

São os filhos do deserto

Onde a terra esposa a luz,

Onde voa em campo aberto

A tribo dos homens nus...

São os guerreiros ousados, que com os tigres mosqueados

Combatem na solidão...

Homens simples, fortes, bravos...

Hoje míseros escravos 
Sem ar, sem luz, sem razão... (ALVES, 2012)

Essa passagem aponta o jogo entre passado e presente que o poeta faz e sobre o qual o crítico projetará o absoluto de uma liberdade incondicionada e restringida posteriormente: “Ontem plena liberdade,/ a vontade por poder.../ Hoje... cum'lo de maldade/ Nem são livres p'ra... morrer..." (ALVES, 2012). Ora, uma vez que essa ideia de "africano livre" é identificada como linguagem e a de "africano escravo" é apresentada como língua, ambas ganham uma essência, tendendo ao conservadorismo da idealização e da homogeneização do que seria o negro antes e depois do processo de compra e venda de escravos, já que ambos são indeterminados historicamente.

A compreensão de que o crítico propõe o termo linguagem aqui acaba por operar num registro metafísico no qual escaparia um entendimento do poema, assim como nos casos dos trabalhos de Costa Lima e Silviano Santiago, como representação. Esta, no caso, seria representação dessa realidade idealizada. Como no caso do trabalho do segundo, também aqui essa ideia escapa, ainda que só na análise do poema de Castro Alves e, diferentemente dele, numa relação quase imediata entre representação e objeto representado. Assim, de modo contraditório ao esforço de Heidegger em romper com a metafísica, ela aqui retorna e claramente há um congelamento dessa unidade idealizada "escravo livre", ao invés de compor um elemento complexo do pré-texto do poema, tal como seu próprio esforço teórico exigiria.

Para Portella, o juízo crítico deve reconduzir a criação poética ao seu nível, tendo uma função redutora e fazendo o para-si da literatura, "num itinerário circular onde fazer crítico e artístico se confundem" (PORTELLA, 1974, p.118), de onde tira das possibilidades "do entretexto" forças para ser criação, metalinguagem, ou seja, para ser crítica (PORTELLA, 1974, cf. p.146). Essa metalinguagem deve estar voltada para o "desvelamento da ideologia do discurso", equivalente à "descrição do entre-texto", ou seja, para a extração da "literariedade, a ideologia como estrutura do mundo a ser revelada" (PORTELLA, 1974, p.146). Uma de suas metas teóricas nesse sentido é operar modificações desse conceito que justificassem seu emprego dentro de uma reflexão propriamente literária. Para tanto, Portella lhe dá o sentido de "energia" produtora e produzida, e cuja compreensão não depende do específico, do particular, mas da totalidade, pois ela é "dinâmica conotativa da globalidade do conjunto dos signos” (PORTELLA, 1974, p.126), “expressão da dinâmica mais profunda” (PORTELLA, 1974, p.129) da interação entre língua e linguagem. É a ideologia de um poema, neste outro entendimento do termo, que faz com que exista um estilo consistente o suficiente para questionar os valores de uma sociedade de modo que haja um "trabalho de unificação, ou 
remanejamento estrutural" que "faz com que uma coisa já conhecida ressurja com outros significados, valores ou modalidades de presença”. (PORTELLA, 1974, p.129)

Ora, temos evitado fazer considerações, até aqui, sobre o rigor acadêmico dos trabalhos para impormos exigências anacrônicas. Contudo, aqui é fundamental que apontemos o que entendemos como incoerência, pois não só ela está no cerne do trabalho, como porque ela endossa nossa hipótese sobre a fragilidade da autonomia do ficcional. Isso porque, como vimos, Portella opera aqui uma visão metafísica da linguagem que, sem dúvida, contradiz a concepção heideggeriana, voltada para o questionamento do pensamento metafísico. A própria tentativa de apropriação do conceito de ideologia apontaria uma ideia de desvelamento que contradiz a oposição entre o ente e o ser, em Heidegger, tanto nesse caso como naquele em que vimos escapar, na análise da poesia de Castro Alves, a ideia de linguagem como diferentes formas de representação de uma realidade idealizada (escravos antes da escravidão e libertação dos escravos).

Nesse sentido, aqui é importante notar que mais uma vez vemos confirmada nossa hipótese sobre a especificidade histórica do conceito de campo literário no que diz respeito, principalmente, à autonomia do ficcional. Isso porque, como podemos ver, os trabalhos que mais afirmam a autonomia do ficcional, quais sejam, os de Portella, Costa Lima e Silviano Santiago, apesar de se diferenciarem quanto à presença desse procedimento demonstrativo nas análises, nenhum deles irá afirmá-la, de modo a por a história dos gêneros literários e das técnicas de composição no centro ou em destaque no problema analítico. Pelo contrário, os trabalhos nos quais a presença da historiografia literária romântica era maior tendem a pontuar o problema num registro mais histórico, ainda que privilegiando o tema tanto na prosa como na poesia. Nesse sentido, a afirmação da autonomia é muito mais teórica do que analítica e ainda assim marcada pela aplicabilidade de modelos não literários de leitura.

Nessa apropriação que Portella faz do pensamento do filósofo, o crítico propõe que o entre-texto não interessa isoladamente, mas conjuntamente com o texto e o pré-texto. Ou seja, a investigação do texto literário do ponto de vista das origens (causas sociais, históricas, literárias etc.) só interessa se ela integra um texto que de fato chegue a se constituir como entre-texto, no sentido de instituir uma linguagem própria, supostamente autônoma em relação a outras discursividades e figuras da verdade, capaz de engendrar um infinito de textos, pois, como estilo, é também abertura de possibilidades. Contudo, dada a brevidade das análises, há mais uma intenção teórica do que uma afirmação, de fato, de autonomia da linguagem literária. Ao fim e ao cabo, Portella apenas repõe, de modo sintético, certo senso comum sobre as assinaturas dos textos literários e sobre os textos literários. Assim, no caso da 
poesia de Castro Alves, ele destaca o albatroz e seus movimentos como imagem da liberdade do homem, e, no caso de "Buriti" e de Uma aprendizagem ou o livro dos prazeres (1969), trata da ruptura com as "estruturas sintáticas convencionais" da língua (PORTELLA, 1974, p.94). Nas três análises, temos uma espécie de reposição das mesmas características que comumente são ressaltadas nesses textos, com a mesma finalidade de reafirmá-los como cânones. 


\subsection{Observações gerais}

Em todas as teses analisadas, é crucial a afirmação da literatura como discurso que fala e é falado por outras disciplinas das ciências humanas e que só pontualmente são específicas ao estudo da literatura. Todos os trabalhos de nosso corpus pressupõem o conhecimento de autores da filosofia, psicanálise, antropologia, sociologia etc. que são orquestrados de acordo com o que os diferentes espaços de circulação intelectual tentam formar como critério de qualidade acadêmica. Contudo, o modo como essas disciplinas aparecem e são articuladas também passa por dilemas comuns, e nisso encontramos semelhanças surpreendentes entre os livros de nosso corpus. Entre elas, destacamos que, naquele momento dos estudos literários, se por um lado a linguagem crítica com pretensões científicas foi estigmatizada por parte do campo literário como modista, arrogante e de inteligibilidade questionável, por outro lado, ela foi reconhecida, como vimos pelo estudo de Costa Lima, quase como um parâmetro natural e inquestionável para o seu progresso. A tendência à objetividade científica nos estudos literários é anterior às leituras que investigamos, bem como às formulações que a contestam, e também está nos trabalhos de nosso corpus $^{37}$. De qualquer forma, a preponderância de um dos termos distingue os estudos literários no século XX, por exemplo, entre Antonio Candido e Afrânio Coutinho ou entre os irmãos Campos e Décio Pignatari ${ }^{38}$.

De todo modo, naqueles meados de 1970, a relação entre arte e conhecimento parece ter tendido a se bifurcar entre leituras que aplicam modelos de leituras não literários sem o estabelecimento de mediações na forma de uma reflexão teórica; e leituras que também aplicam modelos de leituras não literários, mas que afirmam a autonomia da literatura como objeto de conhecimento que exige uma reflexão teórica particular, como no caso dos trabalhos de Costa Lima e Portella, detidamente, e no trabalho de Silviano Santiago de modo disperso.

\footnotetext{
${ }^{37}$ Uma breve frequentação dos debates literários na segunda metade do XIX indica que boa parte das diferenças entre Sílvio Romero e José Veríssimo passa pela afirmação de certa objetividade científica do primeiro e pela afirmação das categorias de análise romântica do segundo.

38 "Semiótica e literatura" (1973), de Décio Pignatari, junto com trabalhos como Metamorfose do silêncio (1975), de Costa Lima, são nesse período expoentes cruciais desse parâmetro do conhecimento no sentido de suas articulações e não em termos absolutos. No caso do primeiro, seu livro cumpriu uma função crucial que indicamos no capítulo anterior acerca da estigmatização da linguagem teórica como hermetismo vazio e pretensioso. A tese do autor se pauta, antes de mais nada, por uma ideia de que a crítica e a teoria literária devem se "atualizar" em relação à literatura de seu tempo. Nesse sentido, Pignatari se esforça na formulação de um modo de compreensão da arte a partir da semiótica de Pierce, apostando numa compreensão do signo linguístico que o ultrapassa e o integra a um entendimento dos signos e dos códigos de modo geral, agora multiplicados e complexificados com a revolução industrial. A tese claramente colocava em cheque o primado da literatura, historicamente definida como a arte constituída por signos linguísticos, bem como se legitima por uma ideia de que, sendo a semiótica ciência e ciência atualizada, pouco haveria de se discutir quanto à sua relevância na análise da literatura moderna de Joyce, Pound, Kafka ou da própria poesia concretista, numa espécie de mútua legitimação entre poesia e teoria.
} 
Não à toa, por exemplo, Costa Lima e Silviano Santiago falam em "re-presentação" ao invés de "representação". Como vimos, no caso do primeiro, o termo é defendido pelo autor como traço fundamental da ficção literária que a aproxima, como arte, da loucura ou dos sonhos porque é "texto que se oculta sob o texto" (COSTA LIMA, 1970, p.399). No caso do segundo, o termo "re-presentação" também foi empregado, como apontamos, no sentido de que "chega-se ao real empírico pelo real re-presentado" (SANTIAGO, 1976, p.83). Ora, em ambos os casos, bem como no trabalho de Portella, vimos que, à revelia das intenções, uma ideia de literatura como representação opera, de formas diferentes, na busca de uma realidade social representada. No caso de Silviano Santiago, nessa mesma passagem o verbo "chegar" indica a finalidade representativa da sua leitura.

Ora, ainda que todos os três criem termos próprios para analisar os textos literários particulares, Schwarz e Merquior também o fazem, o que nos leva a indicar mais esse traço de semelhança entre os cinco trabalhos, qual seja, certo desprezo pela historicidade específica de procedimentos particulares, como: tema, enredo, personagem, metrificação, ritmo do verso ou do poema, emprego de vocábulos e expressões, construções sintáticas etc. De modo geral, todos esses elementos aparecem quando o analista quer dizer que o texto literário promove alguma ruptura, seja com o que seria algo do cotidiano (sonoridade, tema, vocábulos etc), seja quanto a escolas, estilos e outros textos literários particulares. A impressão que temos é que eles nunca interessam em si mesmos porque estão, acima de tudo, sempre em função da construção de um nome, com percurso, divisão e unidade de uma obra e de um estilo. Daí também a ruptura sintática ser o centro da análise e da valoração literária, como veremos, para Portella, mas não ter interesse descritivo; ou o tema despertar interesse descritivo, como vemos no caso do trabalho de Schwarz, mas ser restrito a uma leitura alegórica. Em ambos os casos desses trabalhos mais radicalmente diferentes em nosso corpus, encontramos em comum essa marca da heteronomia, qual seja, certo desprezo pela história dos procedimentos literários que talvez seja inerente a qualquer emprego de modelos não literários de análise.

Assim, mesmo que encontremos o esforço, em alguns trabalhos, de entender o ficcional como realidade objetiva em si mesma - que reproduz outras realidades simbólicas, também contingentes, e a partir da qual pode se chegar a possíveis verossímeis, não a um real em termos absolutos -, esse esforço não foi o bastante para mudar a hierarquia dos discursos e alçar o ficcional ao primeiro plano da linguagem analítica. O trabalho que vai mais longe nessa direção é o de Silviano Santiago, ainda que sua tentativa tenha mais marcas de um entendimento do ficcional como representação do que no caso do trabalho de Portella. 
Ora, essa fragilidade da autonomia do ficcional se coaduna com o fato de que em quase todos os trabalhos de nosso corpus a historiografia literária romântica estava presente. Acreditamos que o emprego de conceitos como estilo de época, escolas literárias, estilo do autor, obra etc. em cada trabalho se deu de modo flexível e tem relação, como dissemos, com as diferentes noções de "rigor" de análise literária. Assim é que, se por um lado Costa Lima, Schwarz e Merquior se dedicam a um estudo profundo de obras, respectivamente, de Cornélio Penna, Machado de Assis e Carlos Drummond de Andrade, por outro lado Portella não se atém ao estudo de um autor e Silviano Santiago escreve, nesse caso, para uma coleção de autores, ou seja, aceita, mas não escolhe esse recorte, privilegiando mais o aspecto da escritura de Drummond e não da obra, ainda que escape uma ideia de "sujeito-obra" cujo percurso caminha para a incorporação dos desejos do pai.

De qualquer forma, junto com o que indicamos anteriormente como a longa duração dessas categorias de análise da historiografia literária, parece apontar uma tendência à abdicação da reflexão da própria arbitrariedade fundamental de suas escolhas teóricas, seja por achar que as leituras estavam justificadas por uma tradição de ensaístas que autoriza o "como se faz" uma análise, seja por achar que o experimento de uma leitura do texto literário, por si só, já é pertinente porque, numa visão progressiva da história, qualquer trabalho que tenha pretensões em ser inovador já tem sua relevância justificada.

Para a compreensão dessa ideia de arbitrariedade fundamental, o texto "Os fundamentos históricos da razão", em Meditações Pascalinas (2001), de Bourdieu, é crucial. Ele foi importante para que os trabalhos aqui analisados não fossem vistos com maior ou menor pertinência em relação a alguma verdade no que toca à compreensão do objeto literário. Isso não marca uma postura relativista em relação a eles, mas apenas uma abertura para a possibilidade de apropriações que levem em conta pelo menos parte da historicidade de formulações tidas como transcendentes, mas que se fundamentam em uma história particular de diferentes discursos e discursividades. Essa abertura, nesse sentido, se dá em nome de uma postura pragmática, não essencialista, cuja meta é recusar qualquer tipo de fascínio fetichista em relação a ideias, assinaturas, livros, procedimentos, vocabulários etc. Aliás, segundo bem repara Bourdieu (2001, p.137-8),

a experiência da transcendência dos objetos científicos [...] constitui essa forma particular de illusio nascida da relação entre agentes providos do habitus socialmente exigido pelo campo e sistemas simbólicos capazes de impor suas exigências aos que os apreendem e os fazem funcionar, dotados de uma autonomia estreitamente ligada àquela do campo (explica-se assim por que o sentimento da necessidade transcendente é tanto mais acirrado 
quanto maior o capital de recursos acumulados e quanto mais difícil o direito de entrada).

Seguindo essa tendência ao dogmatismo na crença nessa transcendência dos objetos literários, notemos que também no âmbito teórico-analítico, quando se trata de fazer referência a pensadores com os quais se discorda, há uma tendência a evitar qualquer discussão mais profunda sobre os mesmos. Assim, as divergências são colocadas apenas em poucos casos, como no dos trabalhos de Costa Lima ou Silviano Santiago, que se atêm longamente em repor e dialogar com leituras e perspectivas diferentes. Mesmo em seus trabalhos, contudo, no caso do primeiro, a lógica da argumentação é quantitativa e não vemos o aprofundamento de nenhuma outra interlocução que não com os textos de Lévi-Strauss; e, no caso do segundo, o que temos é menos uma discussão do que uma reposição de outras três leituras daquele momento da obra de Drummond ${ }^{39}$. Ou seja, em geral, o que há é uma espécie de tendência à interlocução subentendida e, por isso mesmo, não aprofundada como divergência, mantendo-se apenas numa compreensão restrita à sua própria compreensão de qual seria o modo legítimo de divergir.

Há, nesse sentido, uma importante distinção que Perelman faz, em Tratado da argumentação (1996). Nesse livro, ele faz a crítica de uma concepção de ordem discursiva "clara e racional", por oposição ao que descreve como expediente, sendo este o juízo de um texto como supérfluo, excedente ou como qualquer discurso que seja assim compreendido e que passe, por sua impressão de artificialidade, a sensação de não estar moldado ao seu objeto. Ora, retomando essa formulação retórica, ouvir o discurso como expediente é algo que depende de diferentes pontos de vistas, bem como de sua conformidade com o objeto, pois são essas diversas visões gerais que determinam os traços de um discurso natural, claro e racional, por oposição ao que é aparente, formal, expediente.

Assim, se no caso dos livros de Costa Lima, Schwarz e Merquior, o que Perelmam chama de "método racional" impera, no caso de Silviano Santiago e de Portella, temos o que ele chamaria de "demonstração formal". Demonstração formal e método racional "têm em comum o rigor; mas o segundo pretende a objetividade; é vinculado a noções como clareza, simplicidade e também evidência, que garantem as premissas, os raciocínios e as conclusões" (PERELLMAN; OLBRECHTS-TYTECA, 1996, p. 572, grifo nosso). Nesse sentido, uma

\footnotetext{
${ }^{39}$ Costa Lima recupera, ao longo de mais de 200 páginas de Estruturalismo e Teoria da Literatura (1973), uma série de formulações dos mais diferentes autores (Kant, Hegel, Charles Bayle, Karl Vossler; Leo Spitzer, Victor Chlovski, Vladimir Propp, Juri Tynianov, Mikhalil Bakhtin etc.) para recusar o que configurará como visão estética e estilística e como formalismo russo. No caso de Carlos Drummond de Andrade (1976), de Silviano Santiago, é feita uma breve introdução retomando os estudos Lira e anti-lira (1968), de Costa Lima, Drummond, o gauche no tempo (1972), de Affonso Romano Sant'Anna e Drummond, o estilista da repetição (1970), de Gilberto Mendonça Teles.
} 
tese como Estruturalismo e Teoria da Literatura (1973), de Costa Lima, por exemplo, que é de uma grande complexidade enquanto gesto teórico e faz referência a textos de muitos autores, autores distantes no tempo e que tratam de coisas muito diferentes, ficaria sob suspeita. Para um olhar educado em um regime acadêmico-departamentalizado, esses procedimentos cheiram à incoerência lógica e falta de rigor, ou seja, de outro ponto de vista, ele seria classificado como demonstração formal e não método racional, como nós fizemos. 


\section{As tomadas de posição em relação ao valor literário}

Vimos, no ponto 2. desta dissertação, que poderíamos empregar a ideia de campo literário como tensão entre autonomia e heteronomia das instituições a partir de suas especificidades e agora retomamos o problema no âmbito do valor literário. Para tanto, primeiro nos ateremos ao que identificamos como categorias de compreensão da história e dos gêneros literários implicados nos critérios da escolha de um texto literário como objeto da análise e da crítica literária. Tomando como base as publicações do período de 1959 a 1979 que levam as mesmas assinaturas de nosso corpus principal, apontaremos as semelhanças e as diferenças quanto ao tipo de objeto sobre o qual escolhem falar. Em seguida, na segunda parte deste capítulo, voltaremos ao corpus principal desta dissertação pra nos determos no problema do valor literário em cada trabalho.

Neste âmbito, interessa-nos o modo de valoração de tal ou tal objeto. Fugindo de uma perspectiva que quer estabelecer normas para julgar outros juízos, temos a intenção de investigá-los como conjunto de textos que afirmam algumas formas de atribuição do valor literário. Nesse sentido, o nosso interesse, aqui, é menos a origem desses valores do que seus modos de funcionamento e tudo o mais que nos permitir pensá-los como virtualidades, potencialidades que apostam em e produzem, por meio do incentivo ou do desestímulo de tais ou tais gêneros literários, procedimentos narrativos, técnicas de versificação, temas etc. Apesar de não haver mais retóricas preceptivas, podemos ver que aqui há regras na atribuição de valor literário, mas que só poderiam ser deduzidas a posteriori e por uma análise que se proponha mais ampla e aprofundada do que a que se faz aqui. Neste capítulo, apenas apontaremos brevemente dimensões específicas da escolha de um texto literário, acompanhadas de uma análise vertical e comparativa dos trabalhos.

Pois bem, os julgamentos de valor em relação aos textos literários variam de acordo com seus diferentes entendimentos e, como já dissemos, a divisão dos assuntos de nossos pontos 3. e 4. é heurística, sendo a distinção feita por nós apenas a fim de que teoria e valor literário possam ser objetos de reflexões aprofundadas. Separar de modo absoluto o como se dá a valoração de um texto do seu modo de compreensão seria, no fundo, admitir que é possível um entendimento neutro, correto ou verdadeiro das questões que tocam tanto o valor do objeto literário como o modo como se constitui. Dado que nosso interesse aqui é chamar a atenção para a presença da tensão entre autonomia e heteronomia do ficcional nos trabalhos, retomemos esse foco no âmbito do valor literário. 
Vejamos que, nesse sentido, também encontramos uma marcante especificidade na historicidade do emprego do conceito de campo literário se comparada àquela a partir da qual foi concebido. Anteriormente negamos que houvesse uma relação de homologia entre o funcionamento do campo literário, apenas especulativo, e as teorias literárias, ficções, críticas, etc. que o integram; e, no âmbito do valor literário, reiteramos nossa recusa. Contudo, poderemos fazer pontes entre uma coisa e outra fora desse registro. Assim, da mesma forma que demos como exemplo, no século XIX, o início da Academia Brasileira de Letras e a frustração de José Veríssimo ao saber que não seria necessário ao menos publicar livros para ocupar uma cadeira ali; no que toca o valor literário, no mesmo período, o parnasianisno poderia servir de exemplo para vermos a força e a fraqueza do que era identificado como específico à linguagem literária.

Não se trata aqui de operar a redução da ideia de autonomia, que fundamenta o conceito de campo literário, a uma escola literária, no caso, o parnasianismo, até mesmo porque, em verdade, ele reúne poetas um tanto diferentes como Olavo Bilac e Alberto de Oliveira. Contudo, essa escola nos serve de exemplo eficaz para mostrar como aquilo que Bourdieu (2005a) chama de antieconomia (cf. p. 101) pouco opera num debate em que os dois maiores adversários na crítica literária do momento compartilham da ideia de que o excesso de preocupação com a técnica leva à frieza dos sentimentos. Encontramos isso nos posicionamentos de Silvio Romero e José Veríssimo ao falar do parnasianismo, em que está claro o pouco espaço que esses valores ligados à autonomia do campo literário têm historicamente, sendo, inclusive, em geral reduzidos, no caso da poesia, a uma valorização de técnicas de versificação:

Poesia em que não contemos as nossas paixões, reais ou fingidas [...] não é para o brasileiro poesia e está fora da nossa tradição poética, que toda ela é sentimental e amorosa. E eu penso que nós é que temos razão contra a impessoalidade e a impassibilidade do parnasianismo absoluto. [...] Assim, durante uma quinzena de anos, fomos verdadeiramente inundados de miríades de sonetos [...] tudo muito certo, muito direito, muito bem arranjado, muito perfeito se quiserem, mas sem emoção, sem ideia, sem pensamento e, de fato, sem arte. (VERÍSSIMO, 1977, p. 214-217, grifo nosso)

duas correntes inteiramente diversas tinham de mudar a feição das cousas e arrastar em suas falaciosas miragens as inteligências nacionais, o naturalismo e o parnasianismo, isto é, aquele a pretensão errada de querer fazer arte e poesia somente com a observação, e o outro a pretensão, não menos errônea, de querer fazer só com os apuros da forma! (ROMERO, 1960, p. 1661, grifo do autor)

Ora, se pensarmos que Silvio Romero e José Veríssimo são os bastiões das divergências literárias fundamentais no âmbito da crítica, naquele momento, é realmente 
intrigante notarmos o consenso em temer os excessos em relação a preocupações com a técnica e a forma literária. Contudo, segundo nossa hipótese de que a relatividade da autonomia do campo literário se deu historicamente de modo frágil, se comparado ao campo francês, no âmbito do valor literário não seria diferente.

Antes de prosseguir, é necessário pensar que valores literários clássicos e marcados pela ruptura romântica estão presentes em todos os trabalhos de nosso corpus como tensão, ainda que tendendo mais para um ou para outro lado. Ambos os modos de valorizar uma obra, não se excluem na prática analítica, mas é necessário distingui-los. Entenderemos aqui como valores clássicos aqueles que se legitimam ou pela existência de uma tradição ou porque empregam um vocabulário, em geral espacial e geométrico, para aplicar valores como a harmonia, a proporção, a coerência, a coesão, a unidade, o ascetismo corporal, moral, político, o desprezo pela comédia, a valorização dos temas altos, sérios etc. Por oposição, entenderemos os valores literários marcados pela ruptura romântica como o apego a diferentes compreensões do novo, da ruptura, à quebra do ascetismo corporal, ao não linear, ao disforme, não narrativizável, ao humor, aos elementos de gêneros baixos, etc. Ora, tudo isso são agrupamentos gerais a partir do que observamos nos textos, ou seja, recolhidos $a$ posteriori. 


\subsection{O gesto de falar sobre}

Neste trabalho, partimos da constatação de que a escolha dos textos literários a serem analisados pelos críticos marca, de início, a atribuição de algum valor literário positivo geral para esses textos. Essa positividade do juízo, ainda que vaga, deduzimos não só de uma visão geral das análises, como veremos, mas também da justificativa implícita nesses estudos de fôlego, nos quais não encontramos nenhuma afirmação radical de um texto literário como exclusiva e absolutamente ruim do ponto de vista do valor literário. Assim, investigamos a produção bibliográfica dos críticos do corpus principal desta dissertação, durante o período de 1959 a 1979, e identificamos alguns traços principais no que diz respeito à parte dos critérios de escolha dos seus objetos literários.

Primeiramente, um elemento que saltou aos olhos, pois constitui uma mudança relevante de interesse nesses vinte anos, foi a perda de prestígio no estudo de textos literários de língua estrangeira ${ }^{40}$. A grande maioria das escolhas objetos literários tidos como nacionais indica que, se por um lado há o recrudescimento de um discurso nacionalista promovido pelos militares, por outro lado, no campo da esquerda e intelectual, de modo geral, o mesmo se deu, tendo o nacionalismo tomado forma de resistência ao imperialismo cultural. Ou seja, de um polo a outro, o nacionalismo tende a ser unanimidade, o que talvez ajude a explicar essa coincidência na produção dos críticos no que toca certa tendência à rejeição de uma cultura intelectual marcada pelo cosmopolitismo e pelo não engajamento prático.

Pois bem, os artigos e ensaios podem ser agrupados, em quase todos os casos, de acordo com três características que teremos como centrais: a primeira é uma classificação temporal genérica dos objetos que constroem (textos anteriores ao século XIX, textos do século XIX, textos modernistas e textos contemporâneos); a segunda é de acordo com a espécie de objetivo que pretende analisar (literatura, outras artes, não artísticos); a terceira se dá em relação a temas que encontramos nos ensaios e nos livros (análise literária, autorreflexão da análise literária, cultura geral e/ou brasileira). Evidentemente essas classificações se misturam e não são absolutas. Dentre elas, deteremo-nos apenas na primeira, ainda que a própria existência das outras duas demonstre que o crítico literário daquela época

\footnotetext{
${ }^{40}$ Sobre o fortalecimento relativamente recente das pesquisas na área de Literatura Brasileira, Rachel Esteves de Lima (1997) comenta: “os dois críticos que mais contribuíram para a valorização da especialização encontravam-se, até o final da década de 50, fora do ensino universitário da área de literatura: Antonio Candido lecionava sociologia na USP e Afrânio Coutinho era catedrático de Literatura Brasileira do Colégio Pedro II. Na universidade, a literatura brasileira, até essa época, continuava a ser ministrada por professores sem formação específica e ainda lutava por conquistar o seu espaço diante das disciplinas de literatura estrangeira."
} 
compreendia a literatura não só como fenômeno cultural, como, por isso mesmo, capaz de falar de hipóteses gerais sobre a cultura e sobre si mesma.

Dentro das divisões temporais, em seguida, apontaremos diferenças de interesse entre prosa e poesia e entre assinaturas. Por ora, apontemos que a quase totalidade dos estudos literários desse críticos nesse período está integrada a três unidades temporais: a) o século XIX; b) o período tido por modernista; c) o período tido por contemporâneo ${ }^{41}$. Ora, essa divisão serve menos para distinguir características dos objetos que estudam do que para perceber diferentes formas de como os textos literários são vistos no tempo. Assim, apesar de Drummond ou Cabral publicarem em 1970, os poemas assinados por eles são vistos dentro de um tempo diferente daquele da poesia marginal. Acompanha, desta forma, as diferenças de linguagens, os diversos modos como são classificadas temporalmente.

A divisão entre esses períodos e, dentro dela, a centralidade do interesse dos críticos no modernismo indica que ambas, divisão e centralidade, são reconhecidas e prestigiadas institucionalmente, ainda que de modos diferentes. Por exemplo, isso aparece no fato de que apenas objetos do século XIX ou tidos como modernistas merecem ser tema ou mencionados nas teses acadêmicas. Ainda que "textos contemporâneos" possam ser temas de ensaios, não há em nosso corpus teses acadêmicas sobre trabalhos de autores mais recentes. Acreditamos que nada há de arbitrário nessa concentração de esforços coletivos, mas que apontam a grande presença da historiografia literária romântica, pautada pela nacionalidade, a qual tem em $A$ formação da literatura brasileira (1959), de Antonio Candido, a principal referência. Nela, o século XIX, como aquele da constituição do estado nação, é a crucial para "história dos brasileiros no seu desejo de ter uma literatura brasileira” (CANDIDO, 1981, p. 25). Do mesmo modo, o período modernista é relevante, mesmo que ausente, porque, efetivamente, como literatura nacional, e não a partir de exceções como Machado de Assis, a literatura brasileira se integraria à literatura ocidental em um suposto pé de igualdade.

Como pudemos perceber no capítulo anterior, o século XIX foi um período particularmente importante também pela problematização da escravidão, algo que nesse momento torna a literatura do período importante no sentido de "registro de origem" de problemas políticos, sociais, antropológicos etc., que seriam tipicamente nacionais. Assim, Alencar ficcionalizaria os dilemas de uma ética burguesa em um país escravocrata, para Schwarz; Castro Alves construiria uma linguagem da liberdade, de um devir da abolição, para Portella; um narrador como D. Casmurro desvelaria o patriarcalismo brasileiro, para Silviano

\footnotetext{
${ }^{41}$ A dissertação Presente invenção: lendo romances brasileiros contemporâneos (2011), de Mario Tommaso, é um excelente guia dentro do debate sobre diferentes compreensões da contemporaneidade do objeto literário.
} 
Santiago, um narrador como "O alienista" (1882) revelaria o autoritarismo do espaço público para Costa Lima ${ }^{42}$. O modernismo, ao qual pertencem 4 dos 5 trabalhos de nosso corpus principal, já seria um período cuja valorização, como tal, afirma mais a autonomia do valor literário, já que ele se destaca pela proficuidade de grandes obras literárias, ainda que essa grandeza esteja vinculada ao problema da autonomia da cultura e da literatura nacional. Além disso, a ele também pertence a maioria dos objetos literários sobre os quais os críticos se debruçam em ensaios e artigos do período.

Por fim, com "textos contemporâneos às críticas" falamos também menos do compartilhamento de um tempo cronológico do que da escolha de textos que, na maior parte das vezes, são assinados por autores ainda não canonizados ${ }^{43}$. Nesse sentido, não falar de textos ou autores de sua própria época também aponta para um "não compartilhamento" de interesses, questões, problemas, dilemas, oposições, convicções etc. que exijam o risco de se lançar no mar aberto de assinaturas anônimas e textos desautorizados. Em geral, os textos que agrupamos sob a insígnia de "contemporâneos" se atêm à poesia concretista, à tropicália e à poesia marginal, fenômenos sem precedentes. Todos são agrupados sob as insígnias de "vanguarda", apenas "pretensamente de vanguarda" e até de "antivanguarda" nos textos dessa época. No caso dessas insígnias, novamente poderíamos colocar em polos opostos Roberto Schwarz e Eduardo Portella. O primeiro, no calor da hora, apenas publica um comentário sobre uma entrevista com o maestro Julio Medaglia, intitulado "Notas de vanguarda e conformismo" (1967), em "Cultura e política" (1970), no qual faz referência à parte dessas manifestações chamadas de vanguarda. Particularmente sobre o problema literário, ele espera o ano de 1985 para publicar a análise do poema de Augusto de Campos, "Póstudo", no artigo "Marco histórico", e o ano de 1988 para publicar "O poeta dos outros", sobre a poesia de Cacaso. Portella, ao contrário, se dedicou intensamente, entre 1960 e 1970, à temática da vanguarda, reunindo seus textos sobre esse assunto em Vanguarda e cultura de massa (1978) que contém "Missão e demissão da vanguarda" (1966); "As perigosas curvas da vanguarda" (1968); "Literatura e comunicação" (1968); “A ideologia do vanguardismo" (1976); e "Vanguarda e cultura de massas" (1977). Em Teoria da comunicação literária (1971), encontramos ainda "Visão prospectiva da literatura no Brasil" (1971) sobre o mesmo tema.

\footnotetext{
42 Aqui nos referimos aos trabalhos Ao vencedor as batatas (1977), de Roberto Schwarz; Fundamentos da investigação literária (1974), de Eduardo Portella; "Retórica da verossimilhança" (1969), de Silviano Santiago; "O palimpsesto de Itaguaí" (1978), de Costa Lima.

${ }^{43}$ Cabe lembrar que Drummond e Cabral, por exemplo, ainda estão publicando nas décadas de 1960 e 1970, mas, nesse período, seus textos já eram objetos de estudos legitimados e tidos como pertencentes ao modernismo.
} 
No caso da opção de Schwarz, segundo sua leitura da entrevista do maestro, a vanguarda estaria vinculada ao que o grande público considera como critério de qualidade. Este "estigma" de que o ibope é o critério de qualidade de um texto literário condena de uma só vez a preocupação comunicativa dos concretistas, a presença e a relevância que os tropicalistas dão aos meios de comunicação de massa e a ênfase na venda de livros dos poetas marginais. No caso dos textos de Portella, ao contrário, vemos uma espécie de cumprimento do que seria o compromisso do crítico e que, para nossa surpresa, é o mesmo de Schwarz, qual seja, o de recriminar a relação entre uma ideia de vanguarda e de cultura de massa, arte comercial, voltada para o grande público, antiarte, etc. Sem explicitar, no caso do que identifica como vanguarda no Brasil, o que seria uma poesia de qualidade, a maior simpatia de Portella vai, no entanto, para o movimento Praxis, por oposição aos concretistas, que teriam submetido a sua linguagem à linguagem da racionalidade técnica. Ao contrário de seu colega docente da UFRJ, Anazildo Vasconcelos da Silva, Portella deixa clara sua suspeita em relação ao que chamou de "paraliteratura", experimentalismo que ameaçaria excluir a palavra e que marcou certo olhar para o concretismo na época ${ }^{44}$ :

as correntes de vanguarda vêm tentando furar o nevoeiro. Mas confundidas pela presença compulsiva da ciência, correndo o risco de cair numa pura racionalização técnica, numa automação. Já optaram pelo signo não-verbal e nos vimos obrigados a identificar essa operação como um mecanismo de fuga. Como recusá-la simplesmente? Precisaríamos dispor da nova verdade (ainda encoberta pela história). E para isso devemos nos engajar sempre mais. (PORTELLA, 1976 p. 121)

O crítico se refere, de modo geral, ao que seria, em relação ao valor literário, "uma atitude ingênua, passiva, em nome de um otimismo desenfreado e inconseqüente" (PORTELLA, 1970, p. 119), dessa forma, ele assume um tom de militância contrária à cultura de massa, definida como "as novas expressões emergentes dos veículos de comunicação de massa - Cinema, Televisão, Música, Periódicos, manifestações diversificadas de anti-arte.” (PORTELLA, 1970, p. 120). Em Teoria da comunicação literária (1976), com o capítulo “A literatura no tempo planetário", o crítico assume um tom de ataque contra a naturalização desses fenômenos como fatos consumados. Nesse sentido, o crítico elogia o livro de poesia Indústria (1967), de Mario Chamie, sendo o único desses críticos que se atém a este escritor e

\footnotetext{
${ }^{44}$ Segundo Anazildo Vasconcelos da Silva, "falam muito na crise atual da arte, mas os gêneros paraliterários desenvolvem-se cada vez mais. Será crise mesmo ou sufocamento? Diante de uma arte que se volta sobre si mesma e isola-se no questionamento de sua linguagem, que se caracteriza pelo experimentalismo, que lança seus signos no próprio vazio, qual a saída possível? Sendo a literatura apenas uma ilhota perdida no enorme espaço da escritura paraliterária, como insistir na demarcação de suas fronteiras? [...] Como justificar as designações correntes como o bom romance policial, a boa telenovela, o bom filme, a boa música e tantas outras?" (SILVA, 1979, p.185)
} 
ao movimento Praxis, racha do movimento concretista ${ }^{45}$. Segundo Portella, ainda que com problemas, o livro marcaria uma experiência de vanguarda que justamente conciliava a exigência de uma linguagem que passasse pela história da literatura e, ao mesmo tempo, não se limitasse a ela, trazendo para o centro dessa poesia, inclusive, o símbolo maior do imaginário em torno dessa ideia de cultura de massa, qual seja, a fábrica, a indústria.

De todo modo, a postura intelectual de ambos é oposta, no sentido de que é oposto o que entendem por novidade artística. Para Schwarz, ela é fruto de um movimento dialético, ou seja, é tornada possível por uma tradição que também a legitima. No caso de Portella, o novo tem como condição de existência a instauração de um devir, numa concepção de tempo artístico em que a obra realmente "nova" é marcada pela unidade do tempo, como vimos. Daí que, nesse sentido, a vanguarda é vista como assunto sério e pertinente por Portella, enquanto para Schwarz ela não possui, como no caso do estruturalismo, nenhuma radicalidade local.

Pois bem, entre esses dois polos de interesse sobre o tema poderíamos colocar novamente os esforços de Merquior, Silviano Santiago e Costa Lima. No caso do primeiro, o crítico coloca o debate como se fosse ultrapassado ou requentado. "Vanguarda, neovanguarda, antivanguarda: reabrindo o debate" (1974) é o título do ensaio publicado em Estruturalismo dos pobres e outras questões (1975b). Ao contrário dos colegas, novamente Merquior tenta abordar a questão em um registro que é o do comentador rigoroso. Ele faz uma espécie de paráfrase comparativa de três textos de crítica literária que circulam na época e que seriam representativos do que considera serem as principais formas de se pensar as vanguardas naquele tempo. Contudo, o crítico não se restringe a um posicionamento acadêmico e faz menção de relance aos concretistas, referindo-se indiretamente a eles com termos como “fanfarronadas científicas” (MERQUIOR, 1975b, p. 20).

Aqui, a sua preocupação central não é a de pesquisa, mas de combate à aliança entre vanguarda e cultura de massa, como o fizeram Roberto Schwarz e Portella. No caso de Merquior (1975b, p. 20), no entanto, ele irá defender certo "bom aristocratismo", explicitando inclusive seu fundo político. Segundo ele,

\footnotetext{
${ }^{45}$ Portella (1978) faz várias referências indiretas aos concretistas, mas aqui se refere diretamente a uma passagem de Teoria da poesia concreta: textos críticos e manifestos 1950-1960 (1972), de Haroldo de Campos, Augusto de Campos e Décio Pignatari: "desde seu nascimento como disciplina autônoma que a Estética exibe ou esconde o compromisso técnico; não fora ela filha do racionalismo. Daí a desinibição com que a nossa vanguarda se auto-define: 'um projeto geral de nova informação estética, inscrito em cheio no horizonte de nossa civilização técnica'. Adoecida ou acometida de vanguardismo, a insegurança da vanguarda encontra proteção no tecnicismo" (PORTELLA, 1978, p. 19). Já no caso da poesia de Mario Chamie em Indústria (1967), o crítico afirma que "o poeta aceita o desafio da linguagem e procura respondê-lo através de uma instauração críticocriativa que nada tem de trapaceira ou evasiva. E por isso não se desvirtua numa espécie de positivismo literário, em que a palavra perdesse a sua função imagística". (Ibidem, p. 30)
} 
o liberalismo genuíno, em arte, se situa do lado da crítica da cultura "aristocrática" e não dos "democráticos", justificadores dos media como eles são (e dos gêneros imbecilizantes que eles impuseram) - pois desde quando o condicionamento das consciências é sinal de liberdade ou democracia? (MERQUIOR, 1975b, p. 20)

Em seguida, o crítico também tornaria explícita o que para nós seria a concepção mais conservadora de cultura, no sentido de propriedade particular de um grupo restrito e como propriedade cujas instituições de ensino reproduziriam. Assim, o crítico também usa a interessante expressão "aventuras irresponsáveis" para falar do que insinua ser certo experimentalismo, o que reforça uma visão educativa e normativa da arte e implica que o concretismo seja julgado pelo acúmulo de sua produção literária, sendo tido como "ainda muito pobre, comparada à opulenta produção literária do modernista” (MERQUIOR, 1975c, p. 200, grifo nosso).

Costa Lima, por sua vez, compartilha a indiferença, no espaço público, de Merquior e Roberto Schwarz. Ele praticamente se abstém do assunto vanguarda literária nesse período e também é o único que se priva totalmente de referências ao concretismo naquele momento. Indiretamente, contudo, encontramos reserva a um valor literário empregado por esse movimento, qual seja, podemos dizer, aquele ligado à condenação do "chato": "Cornélio Penna é conhecido por mínimos leitores. [...] Em suma, porque é um chato. Não valerá a pena estudá-lo para saber se assim o sucede por deficiência ou sucesso de qualidade?" (COSTA LIMA, 1976, p. 32). Ainda que, de imediato, o crítico esteja interessado em recusar a ideia barthesiana de prazer do texto, fica evidente o que seria uma crítica à formulação concretista de que a poesia deve ser "legal", no sentido de integrante de uma sensibilidade que não conseguiria mais ler a literatura em sua dimensão tediosamente linguística, mas que passava a ser experiência como apelo visual e auditivo.

Por fim, Silviano Santiago é o único dos cinco críticos que em "O assassinato de Mallarmé" (1975) e "Paulistas e mineiros" (1974) se detém menos no assunto vanguarda e mais nas poesias e canções com ela identificadas e, por isso, deteremo-nos mais em seu texto. No caso do primeiro ensaio, ele se atém em pensar justamente a diferença, que para ele é central, entre uma postura vanguardista que marca o movimento concretista e a poesia marginal. A própria comparação entre eles já marcaria, por si, certo valor literário positivo para ambos. Isso porque o crítico rompe com a disparidade com que eles foram tratados, quase como se os poetas marginais estivessem fora da história literária para que não pudessem se seguirem àqueles poetas de 1950 e muito menos aos modernistas.

Fazendo uma leitura claramente simpática à poesia marginal, Silviano Santiago deixa implícita sua preferência pela poesia que escolheu a "vida" ao invés da "vida letrada", tal 
como para eles se dá o esforço concretista de se colocar num cânone universal por meio de uma linguagem igualmente cosmopolita, no sentido mais erudito do termo. No entanto, o tipo de abordagem que faz contribuiria, de certa forma, menos para um elogio dos poetas marginais do que para a existência dessas poesias na história da literatura, sendo o único que apresenta com certa profundidade as histórias do seu movimento e do movimento concretista.

Ora, a comparação de Silviano Santiago também circula entre poetas. Vejamos o poema "Estilos de época", de Cacaso, em Beijo na boca (1975), para sentir a distinção em relação aos concretistas e que será também pretendida pelos poetas marginais: "Havia/ os irmãos concretos/ H. e A. consangüíneos/ e por afinidade D. P.,/ trio bem informado/ dado é palavra dado/ E foi assim que a poesia/ deu lugar à tautologia.” (BRITO, 1985, p. 106). O livro como edição é o eixo do ensaio de Silviano Santiago para explicitar e insinuar diferenças entre os concretistas e marginais. No caso, por exemplo, de Preço de passagem (1972), de Chacal, o livro, "objeto-mercadoria, isto é, transável" (SANTIAGO, 2000, p. 195), é um envelope amarelo com o título carimbado e com folhas mimeografadas soltas dentro dele. Ele é comparado com "as produções tridimensionais e 'as caixas' de Augusto de Campos, com os cartazes-desenho industrial de Décio, com o papel de mancha gráfica perfeitos, de Mario Chamie, ou ainda e finalmente com as execuções em acrílico do poema 'Processo'." (SANTIAGO, 2000, p. 189).

Essa diferença é acompanhada daquela entre a própria linguagem da poesia e inclusive com os mesmos termos. Assim, a poesia de Chacal teria "o descuido como marca; texto pouco asseado e contraditório. Texto de vocabulário e sintaxe coloquiais [...] onde se nega o que mais de perto comandaria o projeto futuro de Haroldo e Décio: a BIBLIOTECA" (SANTIAGO, 2000, p. 192). Ela então nega as instituições no sentido de negar o "vocabulário precioso e as situações históricas inusitadas" que marcam um poema como "Lenda", de Décio Pignatari: “Astorus, o polvo, e a rúbia Ardentéia,/ Incendiária de cristais as barbas do Senatus,/ Celebram suas bodas na Angra de Rapion,/ O velho golfo, manso eunuco de ventre em desalinho.” (PIGNATARI apud, SANTIAGO, 2000, p. 192)

Ora, poderíamos dizer que a oposição entre a vanguarda da poesia concreta e a antivanguarda da poesia marginal acaba por ficar mais no âmbito do comportamento do que no propriamente poético, na medida em que os termos de tratamento poético não ultrapassam a oposição entre a linguagem coloquial e erudita. Segundo Silviano Santiago (2000, p. 193):

Se o marginal, enquanto comportamento social e proposição artística, não é uma atitude nova, pois é praticado e teorizado desde as primeiras proposições de Tropicália (e basta citar o trabalho Subterrania, de Hélio Oiticica), já a crítica que se faz à postura vanguardista é um dado recente. 
Apesar de ter sido forte no cinema com Antonio de Almeida, Sganzerla ou Neville de Almeida, "quando transposto para a sensibilidade dos poetas, tem se primado mais por um comportamento estetizante do que social, visto que os poetas 'frenéticos' ainda guardam ligações bem íntimas com o sistema." (SANTIAGO, 2000, p. 193, grifo do autor). Referindose ao grupo de poetas que assinam os livros de poesia que constituem a coleção "Frenesi", lançada em 1974 - grupo do qual Roberto Schwarz fez parte em seu momento como poeta, com Cacaso (Antônio Carlos Ferreira de Brito), Francisco Alvim, João Carlos Pádua e Geraldo Eduardo Carneiro -, Silviano Santiago aponta que, para eles, ser lido era um valor positivo em si mesmo e isso fez com que

poetas jovens se dedicassem mais e mais a um poema que pudesse ser facilmente digerido pelo leitor comum. Assim como nas artes plásticas, falase de um retorno ao suporte-quadro, na poesia há um retorno ao suporteverso. Verso que se encontra despreparado culturalmente para as grandes investidas livrescas e eruditas da vanguarda. Um leitor que tem poucas leituras e um parco conhecimento literário, pois aquelas e este se encontram circunscritos a determinados valores que são os da juventude das grandes metrópoles. A biblioteca deixa de ser o lugar por excelência do poeta e o seu país é o mass media. (SANTIAGO, 2000, p. 197)

Apesar de não se ater ao "Mallarmé assassinado", como pressupõe o título do texto, fica evidente que a poesia marginal, "o assassino", é absolutamente suspeita do ponto de vista do valor literário, pois, no fundo, é entendida da mesma forma que o comportamento individualista das grandes cidades: "literatura de eus ciclópicos e formidáveis, que brandem com não conformismo o alaúde de uma poesia neo-romântica e anárquica" (SANTIAGO, 2000, p. 199). Apesar da simpatia com o elemento "anárquico" que assassina e rejeita a ideia de superioridade da cultura legitimada pelas instituições e que no fundo marcaria as linguagens das vanguardas, dos concretistas, de Mallarmé, de Pound etc., Silviano Santiago critica o que parece indicar aspectos do individualismo pequeno-burguês do movimento ${ }^{46}$. Tanto é assim que seu ensaio se encerra citando a poesia "O homem e a letra", de Affonso Romano Sant'Anna: “Aqui estou Eu confiante Eu pressupondo Eu erigindo/ Eu cavalgando/ Eu remordendo/ Eu renitente Eu acorrentado Eu Prometeu Narciso Orfeu." (SANT'ANNA apud SANTIAGO, 2000, p. 199)

\footnotetext{
${ }^{46}$ Para o crítico, em "A literatura e suas crises" (1978), haveria duas posturas possíveis no que toca o escritor: ou ele pensa a partir da noção de crise que constitui a modernidade, ou ele segue seu leitor pequeno-burguês e "opta por trabalhar em total descaso tanto pelos valores da literatura, quanto pela reflexão sobre a linguagem, como ainda pelo seu meio de comunicação com o público. [...] $\mathrm{O}$ escritor concentra pois toda a sua energia na busca envolvente de uma postura sócio-política correta e no mapeamento de problemas concretos ocasionados pelos descaminhos da sociedade e do governo dos homens. Ele faz de conta que não existem crises artísticas na modernidade, nem mesmo chega a pensar os motivos pelos quais a atividade de escritor nos nossos dias não pode ser desvinculada de uma reflexão teórica. Se opta por uma linguagem e um tema jornalísticos, vemos já a que nível ele coloca de antemão o seu produto.” (SANTIAGO, 1982, p130)
} 
Após essa breve exposição sobre o valor literário atribuído à produção literária de acordo com seu recorte temporal, vejamos dentro de três unidades temporais principais como se dá a hierarquia entre prosa e poesia. Assim, observemos a diferença de interesse por textos de prosa e de poesia, que pertencem aos três períodos que vimos como hegemônicos (o fim do século XIX, o modernismo e os contemporâneos) e atentemos para o fato de que Roberto Schwarz é o crítico que menos demonstra interesse pela poesia como objeto de estudo (apesar de publicar dois livros de poesia), já que não publicou, nesses 20 anos, nada sobre esse gênero. A ele se seguiriam, poderíamos dizer, Costa Lima, que não estuda poesia contemporânea, e Silviano Santiago, que não estuda poesia no século XIX.

No caso da prosa, escolhida com exclusividade em nosso corpus principal por Roberto Schwarz e Costa Lima, críticos marcados pela objetividade científica, ela costuma apresentar uma linguagem mais próxima das categorias lógicas com que convivemos no cotidiano e nos discursos legitimados como de conhecimento. Já a poesia, por sua vez, foi escolhida pelos autores cujas perspectivas estavam engajadas em romper com a racionalidade científica e com uma linguagem respeitosa da gramática e da lógica. Evidentemente que essas não são características essenciais a cada gênero, mas o modo como em geral eles vêm sendo simbolizados e praticados num mundo que exige da literatura sua função, missão, utilidade, etc., ou seja, que tende a vê-la como inútil, pois concebida como instrumental.

Vejamos como essa diferença de interesses pela prosa e pela poesia se deu de modo semelhante em relação aos períodos do século XIX e do modernismo. No caso do primeiro, se junta ao desinteresse de Schwarz pela poesia, os de Silviano Santiago e Merquior. Apenas Costa Lima, com seu estudo sobre Eu, de Augusto dos Anjos, e Eduardo Portella, com seu estudo sobre "Canção do Exílio", de Gonçalves Dias, se debruçaram sobre a poesia do período. No caso da prosa, Machado de Assis se destaca despertando o interesse de Schwarz e Costa Lima, por sua obra inteira ${ }^{47}$; em especial por "O alienista" (1882), por parte de Costa Lima; e por Dom Casmurro (1899), por parte de Silviano Santiago. Roberto Schwarz e Silviano Santiago têm especial apreço pela prosa do período, se atendo ambos, por exemplo, ao romance Ateneu (1888), de Raul Pompéia e, de José de Alencar, ao romance Senhora (1875), por parte do primeiro, e aos romances Iracema (1865), Ubirajara (1874), Guarani (1957) e Motta Coqueiro ou A Pena de Morte (1877), por parte do segundo. Schwarz também escreveu sobre o romance Canaã (1902), de Graça Aranha, em ensaio publicado em A sereia e o desconfiado (1965).

${ }^{47}$ O capítulo III ("Sob a face de um bruxo") de Dispersa demanda (1981), de Costa Lima, se atém aos romances da segunda fase de Machado de Assis. 
No caso do modernismo, quase todos os cinco críticos se debruçam sobre a sua poesia, até mesmo Schwarz, apesar de não se ater a nenhum poema, se debruça sobre os textos de reflexão poética de Mário de Andrade, em "O psicologismo na poética de Mário de Andrade" (1961). Do ponto de vista da assinatura, Carlos Drummond de Andrade e João Cabral de Melo Neto foram objeto de interesse poético de 4 de 5 dos críticos de nosso corpus nesses 20 anos. Junto dessas assinaturas, encontramos interesse ainda pela poesia de Murilo Mendes, por parte de Merquior, em “A pulga parabólica” (1971); e pela poesia de Mário de Andrade, por parte de Costa Lima, em Lira e antilira (1968).

No caso da prosa modernista, também encontramos uma dupla de assinaturas que será consenso de interesse desses críticos: Guimarães Rosa e Clarice Lispector. Nesse período, encontramos estudos específicos sobre esses autores assinados por Roberto Schwarz e Costa Lima. Ao Grande sertão: veredas (1956), de Guimarães Rosa, e a Perto do coração selvagem (1959), de Clarice Lispector, dedica-se Roberto Schwarz. Costa Lima também se debruça sobre Grande sertão: veredas (1956), em Por que literatura? (1966), sobre a novela Buriti (1956), em Metamorfose do silêncio (1974), e sobre o livro Tutaméia (1967), todos de Guimarães Rosa; e sobre a Paixão segundo G.H. (1964), de Clarice Lispector. No que se refere a Silviano Santiago, há referências a Clarice Lispector e Guimarães Rosa em seu panorama do momento modernista da história literária nacional, em "Vale quanto pesa (a ficção brasileira modernista)" (1974); e, no caso de Portella, também encontramos menções importantes sobre Buriti (1956) e sobre o romance Uma aprendizagem ou livro dos prazeres (1969), de Clarice Lispector, em "Criação e sociedade de consumo", publicado em Vanguarda e cultura de massa (1978), ensaio no qual menciona, de modo geral, as obras desses dois prosadores. Somente Merquior, curiosamente, se detém na poesia modernista, não falando de nenhum prosador do período.

Caberia notar que pouco interesse aparece por textos literários assinados por autores tidos fora cânone modernista que já se consolidava. Ainda assim, contudo, há algum estudos sobre estes, por exemplo, Schwarz deteve-se em Amanuense Belmiro (1937), de Cyro dos Anjos, e em Três romances ppps (1977), de Paulo Emílio Sales Gomes; Costa Lima ateve-se a São Bernardo (1934), de Graciliano Ramos, e a toda a obra de Cornélio Penna; e Silviano Santiago explorou A Bagaceira (1928), de José Américo de Almeida.

Por fim, é oportuno observar que, nas teses acadêmicas, todas as assinaturas dos romances e poemas analisados já estavam consagradas naquele momento e o problema do 
valor literário já se colocava de antemão em segundo plano. A diferença de relevância do valor literário na tese e no ensaio ou no artigo é grande não só por razões enunciativas e pragmáticas, mas porque, tanto na opção epistemológica como na ontológica, não há preocupação em defender um valor literário como um absoluto, mas como o que é historicamente, antropologicamente, filosoficamente, sociologicamente etc. defensável. Há uma tendência geral, nesse sentido, em valorizar o que supostamente seriam teses em cada romance ou poema e/ou as que seriam criadas a partir deles.

Poucos são os que se aventuraram, naquele momento, a pensar as poesias marginal e concretista. As poesias de autores como Cacaso, Chico Alvim, Chacal etc., independentemente do valor literário que atribuímos a elas, desafiam ideias tradicionais de eu lírico, da relação entre poesia e humor, de verso, de ritmo, de unidade poemática etc. Contudo, a falta de análises mais detalhadas talvez tenha implicado pouco questionamento dos operadores de leitura convencionais empregados na leitura dessa poesia. Nesse sentido, não à toa, Cacaso foi tido como teórico dessa geração ou Augusto de Campos disse ter ido fazer crítica por incompetência desta ${ }^{48}$. É no mesmo tom que alguns críticos tentaram desqualificar essas poesias, até mesmo como antiliterárias, da mesma maneira pela qual o elemento visual foi visto por muitos no que toca a poesia concreta ${ }^{49}$.

Do mesmo modo que a ausência de textos examinando caso a caso os poemas chama atenção, também a cultura popular e a cultura de massa não aparecem como problemas que

\footnotetext{
${ }^{48}$ Segundo Augusto de Campos, "A teoria não passa de um tacape de emergência a que o poeta se vê obrigado a recorrer, ante a incompetência dos críticos, para abrir a cabeça do público (a deles é invulnerável)." (CAMPOS; CAMPOS PIGNATARI, 1975, p.5) Este lugar que Cacaso ocupa foi apontado por Lucius Provase em sua dissertação Da experiência de escrever ao ato de escrita: vida e arte na poética de Cacaso (2010). Isso não quer dizer, para que fique claro, que esses poetas se engajaram meramente num esforço de autoelogio: se no caso da poesia concreta isso se transformou em esforço teórico, no caso de Cacaso também houve essa tendência e um espírito pouco condescendente. Um exemplo seria o fim de sua resenha ao livro de poemas $O$ vôo circunflexo (1981), de Rubens Torres Filho, futuro professor de filosofia da USP, dizendo que este "tem muito a ensinar e um pouco a aprender com a geração de poetas marginais [...] onde a força está do lado da experiência revelada, mas que padece de incultura e desqualificação formal." (BRITO, 1997, p.258, grifo nosso). O exemplo que escolhemos não foi à toa. Ele indica bem que, apesar de poeta e integrante desse movimento poético, os termos para se referir a ele são do mesmo tom e emprega termos indiretamente clássicos e pouco descritivos no momento de emitir um juízo mais generalizante.

${ }^{49}$ Nesse sentido, não à toa, formulações críticas que se apegam à ilusão objetivista de definir ou não o que é literatura ou poesia têm boa acolhida em uma comunidade autoritária em relação ao gosto. Afinal, se não há objeto não há problema crítico e valorativo que mereça ser levado a sério. Aqui, tanto Merquior fala em antiarte, nesse registro, quanto, logo depois, Iumna Simon e Vinícius Dantas (1985, p.56) terão a mesma postura diante de elementos poéticos que não se adéquam aos seus gostos. Ao falar que a poesia marginal não tem um projeto como a poesia concreta, dizem que "a pluralidade de tentativas, com tantas características díspares e divergentes, converte-se quase que involuntariamente na expressão de um mesmo dado comum, traduzido na estilização informal e antiliterária. A desqualificação do poema vem então a calhar ao conteúdo dessa sensibilidade". Também ao falar que essa poesia encurta a distância entre sujeito lírico e empírico, os autores dizem que "mesmo assim há elaboração, involuntária ou não, pois a representação dispõe formalmente seus elementos: o registro confessional e biográfico, a anotação irreverente do cotidiano, a nota bruta do sentimento, da sensação, do fortuito, são soluções poéticas que acabam impondo um padrão informal e antiliterário de estilização." (Ibidem, p.56).
} 
mereçam atenção particular e não se destacam o bastante para o que parece ser um gesto óbvio em qualquer crítica cultural, qual seja, analisar a letra de uma canção, uma imagem ou um poema. Esta certa indisposição para a análise dos elementos textuais acaba implicando que o elogio de um texto literário continue passando por apresentar uma "experiência tida por comum”, por oposição, principalmente, à restrição da cultura de massa, que não falaria nada sobre as contradições sociais ou sobre grandes problemas filosóficos.

Contudo, o que se chamava de "experiência comum" é colocado sob suspeita em um mundo no qual os lugares de fala passam a ser questionados como lugares de poder ocupados por sujeitos movidos por interesses, seja no âmbito discursivo de modo geral, seja no teórico, analítico, valorativo etc. Assim, a ausência de uma postura preceptiva não se dá efetivamente, na medida em que essa reflexão sobre o lugar da crítica vai sendo abandonada, ao mesmo tempo em que se automatizando quanto ao estabelecimento de uma epistemologia ou ontologia como parâmetro de compreensão e julgamento geral do objeto literário. Num caminho unilateral, o crítico passa a considerar, sem maiores especificações do texto como possibilidade própria à história dos procedimentos literários, que quanto mais próximo do que entende por conhecimento válido do mundo, melhor o texto literário. Vejamos como isso se dá nas análises do nosso corpus principal. 


\subsection{Caso a caso}

\section{Ao vencedor as batatas}

Do ponto de vista do valor literário, Ao vencedor as batatas (1977), de Roberto Schwarz (1977, p. 25), novamente está no polo da heteronomia dentre aqueles trabalhos de nosso corpus. Isso porque o valor literário positivo é determinado pela capacidade de um romance de "registrar" em sua matéria seu momento histórico:

o escritor sobrepõe uma forma a outra forma, e é da felicidade dessa operação, desta relação com a matéria pré-formada - em que imprevisível dormita a História - que vão depender profundidade, força, complexidade dos resultados. (SCHWARZ, 1977, p. 25)

Apesar de imprevisível, contudo, é a História que a matéria, "que ordena como pode, questões da história mundial” (SCHWARZ, 1977, p.25), deve organizar, conhecer, ter visão crítica; estando essa ideia de crítica ligada fundamentalmente à sociologia de caráter marxista.

Aqui, é fundamental apontar que, se no capítulo anterior não indicamos nenhum tipo de anacronismo neste estudo, pois não era nossa intenção corrigi-lo e estabelecer para ele um parâmetro historiográfico, contudo, no âmbito do valor, será inevitável resvalar nele, pois aparecerá na forma de cobrança, no sentido de apontar o modo como o romance deveria ter sido feito para ser bom. Assim, por exemplo, Schwarz (1977, p. 132-3) comenta que a impessoalidade moderna de Estela e Luís Garcia resulta em "imobilismo", dado que "a consciência da situação é aguda, sem que se transforme em consciência de classe", de modo que "a sua dimensão coletiva não tem sequência, e seus resultados são vistos na ótica do decoro e da dignidade da pessoa, o que os recupera para a esfera do paternalismo." Esse anacronismo é transformado em racionalidade, de modo geral, ao permitir hierarquizar os romances de Machado de Assis de acordo com a mudança de temas, vista como uma “evolução do discernimento do autor”. Falando sobre a maturidade de Iaiá Garcia (1878), Schwarz (1977, p. 119) afirma que o autor

retomava a naturalidade da consideração dos bens da vida, que era a força de A mão e a luva [...] enquanto que dos melindres de Helena ficava a sensibilidade para a opressão, que era a sua componente crítica, e desaparecia o moralismo. Assim, o desencanto sem revolta de Iaiá Garcia era uma síntese precisa e refletida do que era vivo nas experiências precedentes.

Sem dúvida, de todos os estudos presentes em nosso corpus o de Schwarz é aquele que mais valoriza o realismo, já que, junto com a naturalidade, entendida como adequação dos 
textos às formas sociais, é a sensibilidade para a opressão que é elogiada aqui, ainda que sua união não baste para garantir a qualidade total do romance, dado seu comprometimento ideológico com o paternalismo. Assim, segundo o crítico, o romance Senhora (1875), de José de Alencar, apresenta uma relação fraca entre forma literária e movimento da realidade, na medida em que no centro do romance estariam as ideias liberais, presentes em um núcleo em que há um tratamento sério e grave dos conflitos, e, na periferia do romance, ele seria mais "desafogado", aproveitando "as evidências do consenso, localista e muitas vezes burlesco, tais como a tradição, o hábito, o afeto, em toda a sua irregularidade, as haviam consolidado" (SCHWARZ, 1977, p. 34). Apesar de tratar de outra matéria, "seu universo [...] não é problemático, exclui a intenção universalista e normativa, própria do romance-liberal da faixa de Aurélia" (SCHWARZ, 1977, p. 34)

Nesse sentido é que a "despretensão" da periferia do romance irá ser oposta, apesar de não necessariamente positiva, às qualificações que sofrerá a construção do conflito central entre Aurélia e Seixas: "efeito pretensioso", "tom empolado", "afasta-se do natural", "não convence". Ora, os termos que constroem a emissão do julgamento de valor do crítico sobre esse conflito central e sobre o romance como um todo são qualificativos que pressupõem valores clássicos e valores marcados pela ruptura romântica. No caso do primeiro, a ele identificamos, principalmente, os valores da unidade, a coerência, a clareza, encontrados em termos como "coisa descabida", "andamento vertiginoso", "acrítico"; "ridículo", presença de "incongruência", "soluções de conveniência", "felicidade verbal”, "incoerência", "desproporção", “desnecessário", “descalibrado". Junto dele, também encontramos a "naturalidade", a "espontaneidade" e a "autenticidade" operando como valores literários, o que se percebe no emprego de termos como: "tom postiço", "sem natural", "exagerada" e "super-afetação" (SCHWARZ, 1977, p. 36-49).

Notemos que, no trabalho de Schwarz, no qual, como já dissemos, encontramos a convivência de valores clássicos e valores marcados pela ruptura romântica, este último se realiza plenamente com os romances da segunda fase de Machado de Assis, em especial, Memórias Póstumas de Brás Cubas $(1881)^{51}$. Entre essas duas fases, o crítico diz ter havido

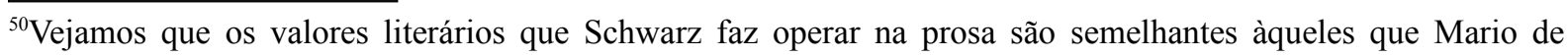
Andrade orquestra em sua reflexão sobre a poesia: "inegavelmente com esse processo de desenvolver pela inteligência a imagem inicial, com estar sempre ao lado do sentimento em contínuas analogias e perífrases a obra de Mallarmé apresenta um aspecto de coisa falsa, de preciosismo, muito pouco aceitável para a sinceridade sem vergonha dos modernistas." (ANDRADE, 1980, p.282) O autor ainda enfatiza a afirmação dizendo em versos: "É preciso não voltar a Rambouillet!/É preciso não repetir Gongora/É PRECISO EVITAR MALLARMÉ!" (Ibidem, p.240)

${ }^{51}$ Nas passagens que se seguem, por exemplo, a comparação é explícita: "quanto à obra futura, assistimos aqui parte da consolidação da sua matéria" (SCHWARZ, 1977, p.73) e "a intriga ultra-romântica organiza fortemente a narrativa, numa direção que não dá continuidade a sua matéria. Ressurreição e $A$ mão e a luva eram livros
} 
uma transição entre o que era um "reflexo involuntário" para uma "elaboração reflexiva"; o que era uma "incongruência" para uma "verdade artística"; o que era um "defeito de composição" para uma "força mimética ou felicidade imitativa". Ou seja, apesar da presença dos valores clássicos, pautados pela racionalidade, verdade, congruência, etc., o parâmetro é uma escrita oposta, tal como está presente nesse romance tido como inaugurador da segunda fase. Ora, isso não deve ser entendido como contradição, porque esse é um estudo de romances cujos méritos são, antes de mais nada, os de terem construído um momento fundamental da história literária nacional, implicando assim uma fusão entre valor cultural e valor literário. Senhora (1875), de José de Alencar, e A mão e a luva (1874), como os outros romances da época de Machado de Assis, trariam "acréscimo em densidade literária e mimética, sem vantagens finais de qualidade" (SCHWARZ, 1977, p. 82).

Opera então, no trabalho do crítico, uma ideia cumulativa de que os romances surgiram na Europa aos poucos, até formarem um "acervo comum" coletivamente, em que se alimentaram e contribuíram "ruins, medianos e grandes" (SCHWARZ, 1977, p. 30). Será então crucial para o crítico afirmar a obra de José de Alencar como fundamental na construção desse "acervo comum", visto principalmente como acúmulo de temas e enredos ${ }^{52}$, mas obra problemática também justamente do ponto de vista do enredo, já que apresenta uma ideologia romântico-liberal, conformista, pois afirma o ideal de interesses não materiais num mundo onde o casamento é um negócio. Há uma tendência a certo conteudismo, nesse sentido, dado que a maior parte da análise dos romances, no sentido analítico e valorativo, será do tema e do enredo.

Roberto Schwarz (1977, p. 30-32) chega a perguntar: "os grandes temas de que vem ao romance a energia e nos quais ancora a sua forma - [...] - como ficavam no Brasil?"; ou a afirmar que o enredo é o "verdadeiro princípio da composição", a "instância formal suprema e a tese social tácita do romance oitocentista" (SCHWARZ, 1977, p. 140) Assim, do ponto de vista do valor literário, o crítico vai contra o romance de Alencar por vê-lo como de "inspiração individualista" e os de Machado como de "inspiração familiar", ganhando o

quase sem enredo, e também Iaiá Garcia é bastante informe. Eram deficiências que para a evolução de Machado seriam virtudes, pois deixavam em suspenso a questão dá forma apropriada ao seu material, que só com o Brás Cubas acharia solução." (SCHWARZ, 1977, p.107).

${ }^{52}$ Falando sobre o papel de Alencar nesse acervo comum, Schwarz toma, inclusive, o modernismo como referência: "a sua obra é uma das minas da literatura brasileira, até hoje, embora não pareça, tem continuidades no Modernismo. De Iracema, alguma coisa veio até Macunaíma: as andanças, que entrelaçam as aventuras, o corpo geográfico do país, a matéria mitológica, a toponímia índia e a História branca; alguma coisa do Grande Sertão já existia em Til, no ritmo das façanhas de João Fera; nossa iconografia imaginária, das mocinhas, dos índios, da floresta, deve aos seus livros muito da fixação social; e de modo geral, para não encompridar a lista, a desenvoltura inventiva e brazileirizante da prosa alencariana ainda agora é capaz de inspirar." (SCHWARZ, 1977, p.31). 
segundo em verossimilhança, pois "a valorização ideológica de um assunto pode ter conseqüências no plano formal..." (SCHWARZ, 1977, p. 68). Ora, no caso do primeiro, Schwarz se refere principalmente aos problemas voltados ao dinheiro, fruto de uma sociedade burguesa em que começa a haver trabalho livre, tal como o casamento pelo dinheiro, por exemplo. Já os temas de inspiração familiar, que marcam os romances da primeira fase de Machado, demonstram que o autor ganha em verossimilhança o que perdeu em desenvoltura crítica. (SCHWARZ, 1977, p. 68).

Essa oposição entre verossimilhança e crítica construiria o dilema que Machado teria de enfrentar e tocaria também o problema do gênero romance. Para o crítico, o que viabilizou a ruptura da segunda fase machadiana foi justamente o abandono da verossimilhança de grande parte dos romances europeus que faziam sucesso na época, tais como os de Balzac, em nome de uma representação alegórica que desse conta da convivência entre uma visão sociológica do que seria a oposição entre o mundo moderno e o mundo arcaico. Do mesmo modo, o melhor romance entre aqueles que analisa, Iaiá Garcia (1878), no qual está presente uma ideologia "civilizatória, antes que crítica" (SCHWARZ, 1977, p. 161), será elogiado, já que permitirá a ruptura posterior do próprio Machado de Assis quanto à "dignificação dos dependentes e [à] crítica moderna do arbitrário paternalista" (SCHWARZ, 1977, p. 148), ao mesmo tempo que fazendo "progressos [...] à elaboração realista de nossa ordem social" (SCHWARZ, 1977, p.117). Como se pode ver, o valor literário aqui se mistura com o valor cultural, já que eles se unem segundo o critério de estabelecimento de "acervo comum" da literatura brasileira, numa espécie de jogo, no caso, menos relativo ao primeiro do que ao segundo.

\section{Verso universo em Drummond}

Antes de entrar na análise que Merquior fará da obra de Drummond do ponto de vista do valor literário, façamos algumas comparações com o estudo de Silviano Santiago que elege o mesmo objeto de estudo, como vimos, nesse sentido superficial. O primeiro apontamento a fazer, e já de saída evidente, é que os poemas mais elogiados são aqueles que mais confirmam a perspectiva crítica dos críticos - ainda quando analisam o mesmo poema. Assim, por exemplo, no livro José (1942), enquanto Silviano Santiago destaca "Viagem de Família", Merquior também o faz, mas sua leitura caminha para uma valorização maior de "Lutador", já que o aspecto metalírico dos poemas é tido em alta conta. Relembremos parte do poema:

O ciclo do dia 


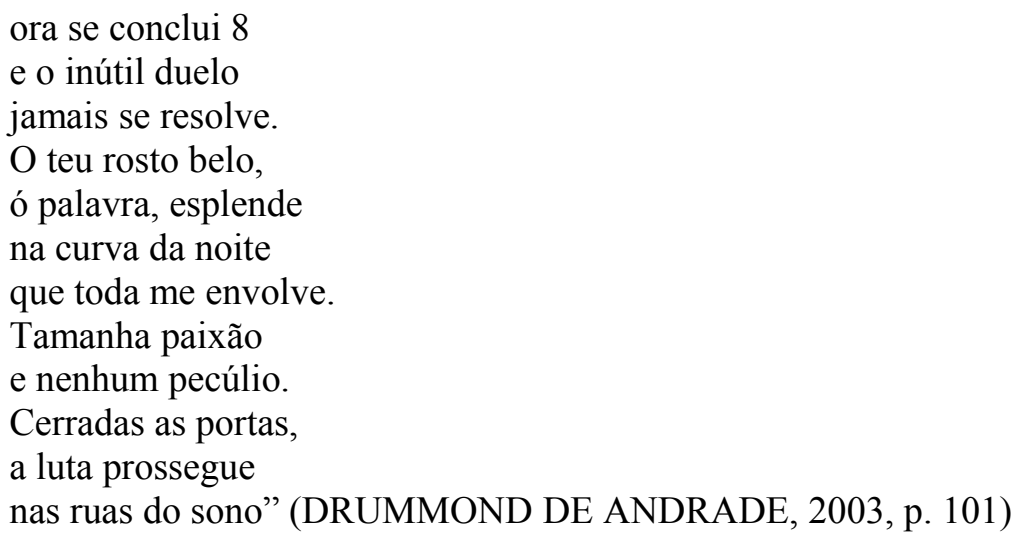

Para Merquior (1975c, p. 69), essa última estrofe marcaria uma idealização das palavras por meio dessa metáfora que chama de "palavras-mulheres". Essa idealização, contudo, não dá a última palavra e, na intimidade (“cerradas a portas"), a luta continuaria. Aqui, é interessante notar um aspecto relativo ao valor literário, no qual melhor nos ateremos na análise de Silviano Santiago, e que toca a capacidade de um poema em figurar modos de relações sexuais, carnais, sensuais, amorosas, etc. Aqui, parece que temos um valor negativo atribuído a esse aspecto e isso podemos perceber no fato de que o poema como um todo carrega um forte sentido sexual e que é dissociado desse problema metalírico. Sobre o que identificou como a terceira fase de Drummond, o crítico elogia poemas como "Destruição" ou "Mineração de Outro", de Lição de coisas (1962), em que a "poesia erótica [ganhou] a profundidade intelectual que se sabe" (MERQUIOR, 1975c, p. 207), ou seja, condiciona o elogio da poesia erótica a um traço fundamentalmente antierótico.

Como comentador, Merquior explicita claramente que o modo como compreende o valor literário está vinculado à emancipação do homem por meio de uma verdade que, reconduziria o leitor a si próprio, à sua condição histórica e existencial. Segundo ele, a obra de qualidade se salva à "penúria semântica", ao mesmo tempo que "o homem se salva com ela, para aí redescobrir, de maneira intermitente e fugaz, a verdade do mundo e de sua própria condição" (MERQUIOR, 1975a, p. 57-58). Na análise dos textos, essa ideia se dá por meio da mediação de uma de conciliação entre a valorização de uma espécie de realismo na poesia, que aqui aparece como valorização do verossímil e da figuração de elementos concretos, e o que seria a valorização de algo a ele oposto, marcado principalmente pela valorização da metalinguagem e dos temas filosóficos.

Apesar de ter em alta conta o que chamou de lirismo filosófico, Merquior elogia a obra de Drummond por ser "reflexo do mundo sociológico e reflexão crítica sobre esse mesmo mundo - ainda que o reflexo não se degrade em documento ou ilustração, e que a reflexão jamais se apresente de forma abstrata e intelectualista." (MERQUIOR, 1975c, p. 72). 
Notemos, nesse sentido, que o crítico quer construir um meio termo entre o que parece ser, no fundo, uma divisão entre concreto e abstrato. Como exemplo, poderíamos lembrar o tratamento que o crítico dá ao poema "A flor e a náusea", de A rosa do povo (1945). Ali o crítico compara o último verso com as estrofes anteriores. Para melhor entender seu modo de valorização, relembremos a estrofe que o antecede:

Sento-me no chão da capital do país às cinco horas da tarde e lentamente passo a mão nessa forma insegura.

Do lado das montanhas, nuvens maciças avolumam-se.

Pequenos pontos brancos movem-se no mar, galinhas em pânico.

É feia. Mas é uma flor. Furou o asfalto, o tédio, o nojo e o ódio.

(DRUMMOND DE ANDRADE, 2003, p.119)

Merquior elogia o poema, mas afirma que seu último verso tenta um valor absolutamente negativo: "o simbolismo fácil, as imagens inorgânicas, esses grandes nomes abstratos (tédio, nojo, ódio) enfraquecem o poema", e haveria uma inibição do patetismo que "prejudica o efeito, torna o verso pouco seguro, a expressão desajeitada." (MERQUIOR, 1975c, p. 105). Aqui, claramente há, opostamente ao como isso em geral aparece, uma valorização positiva da figuração de elementos concretos, e que poderíamos ler como elogio da presença do que é entendido como figuração de uma experiência supostamente comum e cotidiana.

Junto com a oposição entre concreto e abstrato, opera aquela entre o individual e o coletivo e, embora presente nos outros trabalhos, aqui ela é estruturadora. Assim, sobre o livro de estreia de Drummond, Alguma Poesia (1930), Merquior diz que ali se afirma uma "teoria da poesia acontecimento", onde há um progresso em relação à "egologia romântica"; à "sacrossanta subjetividade", a "ilusões do cogito narcisista"; à poesia como "psicofania"; ao "individualismo narcisista"; à fidelidade à "metafísica da subjetividade" (MERQUIOR, 1975c, p. 26-27). Junto com Brejo das almas (1934) e Sentimento do mundo (1940), tais livros marcariam o vínculo inicial da obra de Drummond com o modernismo e a negação de um individualismo romântico, o que garantiria de imediato sua entrada nesse cânone.

Pois bem, dentro do modernismo, vejamos que Merquior ressalta o que seriam procedimentos tidos como surreais, fora do que seria o registro individualista de um neorromantismo inspirado na questão social (cf. MERQUIOR, 1975c, p.45), irmão do neonaturalismo, no qual pintores e escritores como Neruda, Jorge Amado e Portinari são agrupados. Assim é que, para o crítico, os melhores poemas de Drummond seriam aqueles que estão fora de um "páthos engajado", deslizando para o humor surrealizante ${ }^{53}$. Seriam eles,

${ }^{53}$ Notemos que, no que toca o valor literário, há uma oposição entre o cômico, o humor, e essa ideia de problemático: "com efeito, suspendendo momentaneamente a perspectiva problemática, o lado cômico da 
"Elegia 1938", "Tristeza do império" e "Dentaduras Duplas", todos publicados em Sentimento do mundo, sendo este último poema anunciador de uma intensa prospecção psicológica, também de caráter surrealista (cf. MERQUIOR, 1975c, p. 47), o que possibilitaria ao poeta uma grande liberdade de imagens e associações consideradas insólitas: “força expressiva bem superior à da adjetivação mais tradicional” (MERQUIOR, 1975c, p. $58)^{54}$.

Ora, lendo os três poemas, é difícil reconhecer o que eles parecem ter em comum, em especial "Elegia 1938", e percebe-se que o que o crítico entende por "associação insólita" e "liberdade de imagens" aparenta ser a mistura de termos do gênero baixo como "dentaduras" ou "telefone". Esses substantivos figurariam, entre muitas outras imagens, um eu lírico que só poderia se ater ao irreal, já que os termos são entendidos no sentido realista: dentaduras, império, sujeito desejoso de ser capaz de dinamitar Manhattan. Esses elementos considerados insólitos, porque não convencionais a uma visão clássica da poesia, estão sempre compondo um sujeito moderno (em seu eu lírico ou se dirigindo a ele) que se debate com a humanidade de sua condição posta diante de um mundo mecanizado.

Essa valorização das poesias com traços tidos como surreais era acompanhada de outro traço julgado positivo, qual seja, o da ruptura com uma "poética do vivido" em detrimento de uma "poética fundada na experiência da linguagem" (MERQUIOR, 1975c, p. 72). Esta última alcançaria a "alta tradição da poesia sobre-a-poesia no lirismo pós-romântico no Ocidente" (MERQUIOR, 1975c, p. 72), de Valéry, Pound, Mallarmé etc., e inauguraria essa dimensão na poesia de língua portuguesa. Contudo, não deve se enganar quem pensa que aqui teríamos alguma espécie de valorização de uma ideia da "arte pela arte", ou seja, de autonomia radical do ficcional. Não podemos esquecer que a valorização do metapoético convive com a valorização da ética do engajamento que denuncia o evasionismo ligado ao individualismo.

Assim também é que temos aqui o elogio a uma "literatura de experiência", termo construído por Blanchot e distinto da "poética do vivido", por se tratar de um "romantismo

poesia da memória de Boitempo tende a frear automaticamente o processo de reafirmação do estilo mesclado iniciado em Lição das coisas. O estilo mesclado se alimenta da visão problemática; com o desaparecimento desta em benefício de uma ótica bufa ou gaia, só pode esmorecer.” (MERQUIOR, 1975c, p.234)

${ }^{54}$ Retomamos um trecho de cada um dos poemas mencionados acima para que se torne mais evidente a leitura do crítico. De "Dentaduras duplas", poderíamos retirar o trecho: "Resovin! Hecolite! / Nomes de países? / Fantasmas femininos? / Nunca: dentaduras, / engenhos modernos, / práticos, higiênicos, / a vida habitável: / ... / A serra mecânica / não tritura amor." (DRUMMOND DE ANDRADE, 2003, p. 81)"; de "Elegia 1938”, a passagem: "Caminhas entre mortos e com eles conversas/ sobre coisas do tempo futuro e negócios do espírito./ A literatura estragou tuas melhores horas de amor./ Ao telefone perdeste muito, muitíssimo tempo de semear." (Ibidem, p.86), e de "Triste Império", o trecho: "os conselheiros angustiados / [...]/ a dor cada vez mais forte dos negros / e sorvendo mecânicos / uma pitada de rapé, / sonhavam a futura libertação dos instintos / e ninhos de amor a serem instalados nos arranha-céus de Copacabana, / com rádio e telefone automático. ” (Ibidem, p.71). 
modernizado, isto é, anti-idealista e anti-sentimental” (MERQUIOR, 1975c, p. 74). Para o crítico, o livro A rosa do povo é marcado pelo abandono do narcisismo em prol de "uma ética do arriscar tudo", ubíqua, aberta a tudo, inclusive à realidade social. Assim, o livro é elogiado por historicizar o "sentimento do mundo", chegando o crítico a falar em "historicismo lírico" (MERQUIOR, 1975c, p. 78). Como no trabalho de Roberto Schwarz, também aqui há uma ideia de que a historicização de um texto literário se dá principalmente por meio da suposição do tema, o que acaba por colocá-lo inevitavelmente no centro da valorização literária. Dessa forma é que poemas de A rosa do povo, como "América" ou "Com um russo em Berlim", para o crítico que frequentemente se atém apenas ao título, tratam de assuntos muito amplos no espaço e no tempo e seriam melhores se estivessem dentro da órbita cotidiana, caminhando para a solidão do homem urbano. Ou seja, se por um lado, o surreal é valorizado, por outro, referências tidas como inusitadas são condenadas, preferindo ambientações tidas como mais verossímeis, estando essa verossimilhança também ligada a representações nacionais.

Caberia notar que este surrealismo acanhado, como valor literário, também vem acompanhado do que chama de "lirismo filosófico", que marca a terceira fase do poeta. Merquior separaria o "gongorismo" de Jorge de Lima de um lado, o "soneto eclético" de Bandeira de outro, enquanto Drummond e Murilo Mendes iriam ao encontro da poesia de Rilke, arauto desse gênero de poesia para ele. Haveria, na terceira fase, marcada principalmente por Claro enigma (1962), uma espécie de conversão metafísica dos temas e do próprio realismo. Comentários como “o fim do 'imperialismo' da poesia filosófica não o impede, seguramente, de manter o nível bem elevado" (MERQUIOR, 1975c, p. 202) deixam claro que a presença da suposta representação de problemas filosóficos nos poemas são fundamentais para a atribuição do valor literário. Essa valorização positiva também se dá, mas em segundo plano, no caso das representações de teorias antropológicas e sociológicas, coisa evidente em outra passagem, na qual afirma que os poemas mais importantes são "meditações filosóficas em torno de um herói da cultura brasileira” (MERQUIOR, 1975c, p. 171).

Por fim, Merquior encerra seu livro construindo um lugar de qualidade inigualável para a obra de Drummond, pois o escritor evitaria os três maiores defeitos do que o crítico chama de "literatura acadêmica", anteriores mesmo ao modernismo de 1922: "o servilismo em relação aos modelos europeus; a cegueira no tocante à realidade social concreta; a superficialidade intelectual.” (MERQUIOR, 1975c, p. 243). A obra do poeta conseguiria percorrer a dialética do local e do universal afirmando, como no caso do trabalho de Schwarz, a presença positiva de traços tidos como autenticamente nacionais. Assim, a obra de Drummond é "nacional por sua linguagem e sua inspiração", sem ter nada de exótica ou ser 
regionalista, pois enraizada. Num momento de transição do Brasil, mas também universal, pois essa mudança também é a do homem moderno, qual seja, a da passagem de um modo de vida agrário a outro urbano-industrial. Ou seja, como no trabalho do outro crítico, a leitura alegórica implica que sejam valorizados os elementos do texto ou da obra que a viabilizem.

Pois bem, como mencionamos no capítulo anterior, na terceira fase de Drummond, composta dos livros publicados de 1948 a 1959, Viola de Bolso (1952), Fazendeiro do Ar (1954), A vida passada a limpo (1958), a predominância do estilo da idade mítica de Broch, segundo o crítico, é o que garante que a escrita classicizada seja uma estratégia legítima (cf. MERQUIOR, 1975c, p. 201). Como nos livros anteriores, os valores clássicos também conviverão com aqueles marcados pela ruptura romântica, mas de modo bem mais evidente. Para Merquior (1975c, p. 191), comparando a presença do estilo clássico e mesclado:

é supérfluo observar que nossa distinção entre esses dois tipos de estilo poético não implica nenhum julgamento de valor: Drummond excele nos dois. O que importa, em compensação, é lançar alguma luz sobre o sentido profundo - significação cultural - dessa classicização do modernismo, cujas qualidades se fazem igualmente sentir, nessa mesma época, na poesia de Jorge de Lima, Murilo Mendes ou Joaquim Cardozo.

Logo em seguida, o crítico se retifica e troca "classicização do modernismo" por “modernismo classicizado" (MERQUIOR, 1975c, p. 191). Isso porque tenta pensar o termo clássico não por oposição ao romantismo, como quando é entendido como período artístico, mas como oposição ao naturalismo. Não haveria classicismo sem "certa abstração do real", dado que "toda mímese classicista - seja ela plástica ou literária - se despoja deliberadamente do desejo de representação 'realista', concreto, da natureza e da sociedade." (MERQUIOR, 1975c, p. 192). Desta forma, em seu trabalho, os valores clássicos seriam semelhantes aos anteriores - coesão, coerência e unidade estilística - com o acréscimo do que entenderia por temas clássicos, quais sejam, filosóficos e metapoéticos, bem como das formas poéticas fixas (cf. MERQUIOR, 1975c, p. 191-2).

Mais do que no trabalho de Schwarz, aqui vemos preponderar os valores clássicos, ainda que não de modo absoluto, como apontamos operar a própria ideia de modernismo classicizado. A forma soneto claramente apresenta um mérito em si mesma, na medida em que, a priori, deve ser praticada e bem praticada:

Drummond participou com brio da renascença do soneto no modernismo classicizado dos anos 40 e 50, quando um Manuel Bandeira [...], um Jorge de Lima [...], um Murilo Mendes [...] asseguraram a essa forma a densidade poética que ela corria o risco de perder nas mãos dos medíocres parnasianos da "geração de 45". (MERQUIOR, 1975c, p. 150)

Contudo, isso que é um valor estritamente literário não afirmaria de modo geral a autonomia do ficcional, dado que, como vimos na introdução do capítulo, também aqui ele 
tende a limitar a autonomia do ficcional às técnicas de versificação, sendo a maior parte das análises do crítico voltadas para a dedução dos poemas segundo o estabelecimento de fases e unidades de estilo que são identificadas, em geral, pelo reconhecimento de diferentes tipos de temas e vocábulos.

\section{A perversão do trapezista}

Assim como no trabalho de Schwarz e Merquior, o trabalho de Costa Lima se debruça sobre uma obra que terá uma evolução que é fundamentalmente positiva. O parâmetro dessa evolução, contudo, se dá a partir do que construirá como variante forte, o romance $A$ menina morta (1954), de Cornélio Penna. Assim, se a segunda fase da obra de Machado será o parâmetro valorativo para a primeira fase e para o romance Senhora (1875), de Alencar, no caso do trabalho de Schwarz, aqui o parâmetro se limita a ser estabelecido dentro de uma única obra em que o último romance publicado pelo autor é o melhor de todos. Em ambos os casos, portanto, há um ou mais romances que estabelecem o parâmetro de compreensão e julgamento daqueles publicados anteriormente, o que é surpreendente no caso do trabalho de Costa Lima, já que sua proposta é a de uma análise sistêmica, ou seja, uma análise horizontal dos romances sem diretamente integrá-los a qualquer tipo de história literária.

Pois bem, no caso do livro de Costa Lima sobre Cornélio Penna, também podemos apontar o convívio de valores clássicos e marcados pela ruptura romântica, bem como o predomínio do primeiro como no caso dos outros dois trabalhos analisados. Uma das primeiras observações que encontramos sobre os romances, no caso, Fronteira (1935), romance de estreia do autor, é que os elementos estão "dispersos e desarticulados", portanto, sem força. (cf. COSTA LIMA, 1976, p. 68). Ora, se o adjetivo é "desarticulado", então o valor literário pressuposto também é o da coesão. Não seria o caso de comentar os romances aqui, mas apenas assinalar que não é difícil notar que o romance eleito como o melhor tem uma linguagem e um enredo que fazem mais concessões ao naturalismo. Fronteira, nesse sentido, é bem mais experimentalista, uma vez que é muito mais difícil identificar nele um tempo, espaço, passado e, principalmente, um enredo ou uma narrativa de acontecimentos.

Contudo, como vimos estar justificada a permanência de Alencar no cânone por sua contribuição para um "acervo comum” por parte de Schwarz, aqui também os romances anteriores a A menina morta (1954) são "salvos", mas por criar um acervo comum interno a uma obra e uma assinatura. Assim, se por um lado Costa Lima concorda com as críticas de Sérgio Milliet em relação a Repouso (1948), no que toca o defeito dos personagens em não 
tomarem decisões, e o "excesso de cláusulas", "palavras convertidas em clichês", "descrição arrastada", "falta de inventividade", "monótono vácuo repetitivo" que isso trazia para a narrativa, por outro lado, seria desta "argamassa" que surgiria o "estilo minucioso" (cf. COSTA LIMA, 1976, p. 89) de A menina morta.

A menina morta apresentaria uma busca por um objeto de desejo que começa em Fronteira, mas passa a ser escrita só em Repouso. Essa busca não é uma origem, mas modos mais ou menos completos de como os níveis paradigmático e sintagmático se relacionam, em que apenas um romance conseguiria conter os elementos de outras variantes de modo a questionar até mesmo o próprio gênero em que está inscrito, como em sua comparação com os romances de Daniel Defoe e Georges Bataille. No fim do seu livro, o crítico compara a obra do autor com outros textos cujas diferenças fariam com que, numa espécie de reação química, fizessem vir à tona os traços dos romances de Cornélio Penna. Esta é, grosso modo, a função das comparações entre o que seria uma unidade de estilo de "Cornélio Penna" com aquelas de Daniel Defoe e Bataille. Retomamos aqui o ponto 5 do último capítulo de $A$ perversão do trapezista (1977), “Coda”, excluído na segunda edição, mas presente na edição do período que nos interessa e no qual o crítico retorna a essa comparação inicial para dar uma amarração final para a sua análise.

Para o crítico, haveria uma espécie de dilema narrativo que o estilo de Cornélio Penna estabeleceria e que se situaria entre o tempo da ascese protestante de Robinson Crusoé e o tempo do que seria seu oposto, o excesso da carne em sua dimensão do corpo, da sexualidade etc., encontrado nas narrativas de Bataille. As narrativas de Cornélio Penna, em especial $A$ menina morta (1954), se constituiriam justamente entre uma tensão repressiva, atemporal e mítica e outra libertadora, romanesca, temporal. Como Roberto Schwarz pensou o "causo", que pressupõe outra racionalidade, traria algum tipo de contribuição ao gênero romance, Costa Lima constrói o discurso mítico como tal, pretendendo provar como ele "pode coexistir, sob a forma de filão, com a corrente mais propriamente reflexiva do discurso poético" (COSTA LIMA, 1977, p. 57). De todo modo, a própria possibilidade de colocação dessa dualidade já é apontada como mérito geral do estilo de Cornélio Penna.

Nesse sentido, outro ponto em comum entre o modo como Costa Lima e Schwarz estabelecem valor literário para as obras é a valorização positiva dos romances que analisam e julgam de acordo com a capacidade que eles têm de romper e questionar o gênero romance. Mesmo que no caso do segundo ele esteja numa nota de rodapé, toda a estrutura do seu estudo sobre Machado tem a possibilidade de subversão do romance realista de um Balzac, tal como entenderia Auerbach, Carpeaux, Anatol Rosenfeld ou o Lukács de Teoria do romance (1916), 
mas que só ocorreria em Memórias Póstumas de Brás Cubas (1881). No trabalho de Costa Lima, essa preocupação com o romance enquanto gênero literário se faz presente, mas por outra via. Aqui, o dito "romance europeu" aparece na comparação feita com Robinson Crusoé (1719), de Daniel Defoe, e História do olho (1928) e Madame Eduarda (1937) de Georges Bataille. No caso do estudo de Costa Lima, Defoe e Bataille são propositalmente autores fora do intertexto dos romances de Cornélio Penna, para que fique claro que comparações ali não são feitas dentro de um registro historiográfico - que opera com uma lógica de busca da origem -, mas de um sistema no qual os autores teriam uma obra que comporia um conjunto de variantes, as quais, essas sim, seriam comparáveis entre si.

As narrativas romanescas de Defoe e Bataille, assim entendidas por oposição às narrativas mutuamente míticas e romanescas de Cornélio Penna, comporiam uma "entranhada percepção da realidade cultural brasileira" (COSTA LIMA, 1976, p. 192), por meio, principalmente do que descreverá como marcas da "suspensão do tempo" em seus romances. Ora, essa suspensão do tempo seria originalmente, segundo Auerbach, do discurso mítico, no qual "o tempo é suspenso porque a seriedade dele exigida e a crença nele depositada supõem uma estabilidade social que anula a preocupação com a dinâmica temporal" (COSTA LIMA, 1976, p. 53). O narrador de um romance como Fronteira (1935), por exemplo, é muito mais um "cronista da suspensão do tempo" do que um observador, e Costa Lima critica esse traço, responsabilizando-o também pela excessiva semelhança das personagens entre si, a ponto de combiná-las, nesse caso, de modo inconsistente (cf. COSTA LIMA, 1976, p. 63). Já no caso de $A$ menina morta, em que temos um início de opulência e um fim de decadência, bem como a repetição de um tempo mítico que deixa advir o segredo, o acontecimento que detona as obscuras transformações das personagens, há a convivência desse tempo suspenso com um tempo em que há transformação, afirmando assim, também, sua superioridade em relação a Fronteira. Deste modo, fica assim insinuada a integração específica de A menina morta no cânone universal, já que sua universalidade está garantida nessa capacidade mesma de construir outra temporalidades.

Pois bem, a qualidade dos romances de Cornélio Penna varia de acordo com a capacidade que têm de, na "superfície do estilo", deixar entrever a presença de uma matriz estabelecida internamente à obra do autor, mas que também leva em conta sua capacidade de representar uma realidade antropológica. No primeiro caso, a presença de uma ideia de funcionalidade acaba por tender a operar com valores literários mais ligados à autonomia literária, na medida em que é interna ao problema literário que estabeleceu o parâmetro valorativo a partir do qual foi considerado como o melhor romance. Assim, no caso de $A$ 
menina morta, a fazenda já está fenecendo economicamente e essa insegurança não explica o clima de medo da narrativa, mas sim a relação que as personagens mantêm entre si. Seus lugares são fixados de forma que os personagens se sujeitam a sua posição só quando não podem rivalizar com outra superior (cf. COSTA LIMA, 1976, p. 113-4).

Para Costa Lima (1976), a presença do sema "fantasma", por exemplo, crescente junto com a função disjuntiva ao longo da publicação dos romances de Cornélio Penna, não é discursivamente significativa, apenas índice de algo, de um elemento que faz parte da "linguagem da ficção", em que o "uso funcional de peças" remete, por sua qualidade, a outra coisa. (cf. COSTA LIMA, 1976, p. 76). Aqui, o termo "funcionalidade" se junta ao termo "articulação" nas passagens em que se valoriza de modo mais diretamente positivo os romances, opondo estes termos ao "modismo da assombração", no qual a língua ainda não estaria formada, sendo ainda mera representação da teatralidade e não re-presentação, linguagem. Referindo-se aos romances como variáveis, afirma que "a qualidade literária de uma obra dependa da articulação de seus elementos, desde a dimensão nuclear - matricial - e de superfície - estilística” (COSTA LIMA, 1976, p. 74).

Nesse sentido, negando um cientificismo mais ingênuo, mas reafirmando a objetividade científica, Costa Lima (1976, p. 88) então se pergunta se "seria a análise algo mais que a racionalização do gosto?" Ao afirmar que a questão do valor literário "predetermina" o trabalho do analista, Costa Lima coloca a questão como se isso ameaçasse a objetividade de sua análise - pois ela se constituiria, no limite, de justificativas pessoais legitimadas por uma tradição, sendo, no fundo, arbitrária. Buscando uma terceira via que marca, podemos dizer, seu trabalho posterior, o crítico buscará o que poderíamos chamar de legitimação epistemológica do juízo do gosto, chegando mesmo a falar aqui que "a demonstração a que temos submetido a proposição sobre a diferença entre a variante forte e as fracas, bem como a solidariedade destas entre si, poderá talvez servir de caminho para a explicação do valor ou não valor literário de obras em prosa.” (COSTA LIMA, 1976, p. 88, grifo nosso). Podemos perceber então que mesmo no caso da afirmação de valores literários autônomos, a maneira como ela se dá é marcada pela heteronomia, dada essa preocupação com a objetividade científica.

Pois bem, passemos ao modo de valorização propriamente heterônomo, pois marcado pelo valor positivo atribuído à representação de contradições sociais, e segundo o qual chama particular atenção a passagem que aponta a obra de Cornélio Penna como uma sequência de romances sobre a decadência das fazendas como unidade produtiva: 
a ficção corneliana é um trajeto na memória. As datas de suas publicações $(1935,1939,1949,1954)$ correspondem a um progressivo recuo cronológico, que é paralelo à visão da pobreza (Fronteira), da decadência mais acentuada (Dois romances), da decadência disfarçada (Repouso) até a opulência material de A menina morta, cujo fim - a fazenda paralisada, os escravos libertos e aterrorizados, os cofres vazios, a casa reduzida a um navio deserto e sem governo - abre para o ciclo que "começará" a ser composto pelos personagens dos romances anteriores. (COSTA LIMA, 1977, p. 85)

Aqui, a hierarquia dos romances dada pela convivência dos tempos mítico e romanesco também acompanha a capacidade de representação dos romances, e ambos são elogiados. Deste modo, algumas representações são mais valorizadas que outras e aqui, mais uma vez, destaca-se o calor dado às figurações da sexualidade. Isso porque a hierarquia presente entre os romances de Cornélio Penna passa de modo crucial pelo afastamento da prosa de Bataille. Segundo sua hipótese, Fronteira (1935) é o único romance em que há uma figuração violenta da sexualidade, ao passo que, nos romances posteriores, o autor optou pelo que seria a acentuação de uma "função disjuntiva" interna aos próprios personagens e fundamental para suas complexidades:

cada parceiro [...] entra em um processo de divisão interna, [...] avesso ao da conjunção sexual. Enquanto essa origina a possibilidade de fecundação de uma terceira unidade, na conjunção disjuntiva, pelo menos um dos pares se torna genitor em si mesmo, sua bipartição. (COSTA LIMA, 1976, p. 91)

Claramente a presença da figuração de uma sexualidade ativa é desvalorizada, aliás, junto com a figuração de outro elemento carnal, a violência, em detrimento do que seriam sentimentos e assuntos mais nobres, como a angústia e a culpa, responsáveis por associar, nos outros romances, a sexualidade ao sema "fantasma". (cf. COSTA LIMA, 1976, p. 65).

\section{Carlos Drummond de Andrade}

Pois bem, passemos então ao modo como Silviano Santiago constrói o valor literário da obra de Drummond em sua publicação Carlos Drummond de Andrade (1976). Primeiramente, é importante notar que, em sua tese, os valores literários talvez tenham sido mais difíceis de serem identificados do que, por exemplo, nas teses de Schwarz ou de Merquior, nos quais as pontes feitas com uma história da literatura brasileira e ocidental são fundamentais para identificarmos o modo como aparecem os posicionamentos no âmbito do valor literário. No trabalho de Santiago, a ideia de escritura é central e implica a valorização de termos que marcariam Drummond como poeta da re-presentação, bem como a valorização de sua poesia como exemplo de fala sujeita à análise psicanalítica. No caso da primeira, ela resulta em chamar a atenção e elogiar os poemas em que há a figuração do ato ou de 
elementos ligados à leitura e à escrita, como o vimos no caso do poema "Infância", e que o crítico tem como um dos mais ricos da obra de Drummond. No caso da segunda, ela resulta em destacar os poemas que mais fortemente figuram a memória da terra natal, a relação com os empregados, a família, a sexualidade etc.

Ambos os procedimentos de valoração são orquestrados de modo a se submeterem ainda a outro, que leria o eu lírico como análogo a uma pessoa na qual poderíamos apontar uma estruturação do sujeito dentro de uma dialética de amor e de morte com o outro, com a lei, com a diferença. Assim é que, quando o eu lírico volta para o espaço de inclusão da família, no poema "Infância", ele o faz como "um Super-Robinson que aproveita a experiência do imaginário alheio, assimila-a, faz do texto alheio o seu contexto, o soma finalmente à sua própria vivência de menino brasileiro, de "criança entre mangueiras"” (SANTIAGO, 1976, p. 53). Ele estaria cheio de sentidos que permitem a reconstrução de uma experiência, no caso, coletiva e objetiva, e subjetiva e individual. Essa experiência compartilhada tem uma dupla função no âmbito do valor literário. Ela é tanto compartilhamento da experiência de constituir-se como sujeito desejante como de um imaginário que integra essa constituição. Em ambos os casos, o valor literário parece ser atribuído, nesse sentido, de acordo com a confirmação ou não da perspectiva psicanalítica lacaniana.

Daí que, nesse sentido, se, por um lado, integrar a obra e a assinatura numa história nacional e mundial da literatura não é prioridade no trabalho de Silviano Santiago, por outro lado, alguns termos dessa compreensão do literário se manterão, como o par opositivo particular e universal. Ora, como a literatura é pensada aqui fundamentalmente a partir de categorias psicanalíticas, fica subentendido que os poemas teriam valor universal, já que todo sujeito se estruturaria assim. No caso do compartilhamento de um imaginário comum, a valorização se dá no que se refere à figuração fundamentalmente da família patriarcal e da sociedade escravocrata. Essas presenças não estão numa relação progressiva entre si, na qual seriam tratadas de modo cada vez mais "completo" ao longo de sua obra. Ao contrário, como aponta em uma nota de rodapé, o conceito empregado aqui será o de "descentramento", de 
Derrida $^{55}$, o que permitiria avaliar um poema como "Infância", de seu livro de estreia, como um dos mais ricos de sua obra.

Vejamos que, nesse último modo de valorização, podemos aproximar o trabalho crítico a outros. Assim, é fundamental apontar que a maior parte dos poemas analisados em comum com aqueles examinados por Merquior são poemas que, de modo mais evidente, ajudam a identificar na obra do poeta, ainda que de formas diferentes, a relação com a família patriarcal e a sociedade escravocrata: "Iniciação amorosa", "Canto Negro", "Viagem na família", "Retrato de família", "Os bens e o sangue", "A palavra e a terra", "Como um presente", etc.

Para ficarmos num pequeno exemplo, vejamos brevemente o caso de uma poesia como "Canto negro", publicada em Claro Enigma (1951), cuja primeira quadra de versos já apresenta um eu lírico que se refere à infância: “À beira do negro poço/ debruço-me, nada alcanço./ Decerto perdi os olhos/ que tinha quando criança.” (DRUMMOND DE ANDRADE, 2003, p. 280). O poema de 12 estrofes, sem número de versos ou métrica definida, é tido como um bom poema por Merquior (1975c, p. 165) pela "síntese de evocação históricorealista e tendência filosófica [...] em que a extrema docilidade dos negros, no quadro da sociedade patriarcal, inspira o poeta através de amores ancilares". Referindo-se à estrofe "Bacia negra, o clarão/ que súbito entremostravas/ ilumina toda a vida/ e por sobre a vida entreabre/ um coalho fixo lunar,/ neste amarelo descor/ das posses de todo dia,/ sol preto sobre água fria" (DRUMMOND DE ANDRADE, 2003, p. 282), o crítico afirma que o seu "cromatismo cultista [...] intensifica o movimento conceitual do poema, que vai da pintura da sensualidade submissa das negras [...] às questões existenciais” (MERQUIOR, 1975c, p. 165).

A mesma estrofe citada acima será analisada por Silviano Santiago, mas antes de comentá-la, é importante lembrar que, se "Canto Negro" será um poema absolutamente secundário no livro de Merquior, neste outro estudo ele é estratégico. Isso porque ele reúne várias imagens que o crítico desdobrou também de outros poemas e que dizem respeito a essa figuração de um sujeito que faz do negro poço um espelho cuja imagem compõe o imaginário com o qual se constitui como ser desejante. Assim, temos o negro, da tinta de escrever, do escravo, da mulher, do padre etc., o passarinho (como símbolo da efemeridade do amor

\footnotetext{
${ }^{55}$ Este conceito foi empregado por Derrida em A escritura e a diferença (1995), ao tratar da abordagem que Lévi-Strauss faz da etnologia e do que aí seria "o abandono declarado de toda referência a um centro, a um sujeito, a uma referência privilegiada, a uma origem ou a uma anarquia absoluta" (DERRIDA, 1995, p.240), a renúncia "ao discurso científico ou filosófico, à episteme que tem como exigência absoluta, que é a exigência absoluta de procurar a origem, o centro, o fundamento, o princípio etc. Por oposição ao discurso epistêmico, o discurso estrutural sobre os mitos, o discurso mito-lógico deve ser ele mito-morfo" (Ibidem, p.241), ou seja, um jogo.
} 
moderno), o poço (como lugar da inscrição, da carne), etc. Nesta estrofe em particular, segundo Silviano Santiago (1976, p. 87),

do antigo sol [...] que irradiava "clarão" lá da "bacia negra" que era onde o adolescente o tinha descoberto, paira agora sobre a água fria do texto sua reminiscência, sua representação, isto é, pálida sombra, negra imagem do fundo poço. Este [...] não deixa que seja entregue com clareza o enigma da incorporação do branco no preto, do preto no branco. Resta ao poema deixar que o enigma se inscreva no fundo do poço, que se escreva e repita, sempre, a mesma cantilena do desejo e do passarinho, sendo este agora de canto negro $[\ldots]$.

Ora, a valorização da figuração das tensões sexuais também é uma distinção importante, de modo oposto aos trabalhos de Merquior e Costa Lima. Isso podemos ver no fato de que o crítico sutilmente sugere a última fase do poeta como a fase que seria mais conservadora, portanto pior, mas não pode explicitá-lo diretamente, primeiro por soar normativo; segundo, porque não pode dizer abertamente que, dentro de sua apropriação, este outro é tendencialmente uma Lei castradora. Como vimos, Drummond teria uma espécie de última fase, na qual o olhar do outro, do patriarca, já estaria incorporado ao dele, diminuindo, "com esse gesto de absorção, a distância entre ele, enquanto outro, e o espaço do mesmo onde circula a figura autoritária do pai e dos antigos é que o fascina mais e mais na idade madura.". (SANTIAGO, 1976, p. 96)

Silviano Santiago se detém no poema "Escritório", de Boitempo (1968): "furtam-se as pratas de dois mil réis / riqueza infinita de uma semana" (DRUMMOND DE ANDRADE, 2003, p. 113) e afirma que, se no gesto do roubo está o desejo de ruptura com o pai, este acabava, de certa forma, esvaindo-se com a indistinção entre o pai proprietário, o pai que institui o tabernáculo e o pai padre na figura da "mão" que é fonte de amor e violência. Quando encerra seu livro falando da metonímia da "mão" como diferentes formas de Leis, de pais, de autoridades etc. presentes nos poemas de Drummond, Silviano Santiago claramente privilegia o tema da autoridade junto com o da tensão sexual. Assim, essa "mão" seria “indiferenciada, pois guarda ela tanto uma mensagem de carinho, quanto de castigo; serve tanto como símbolo de doçura como de vingança. [...] O tapa é apenas uma 'maneira mais dura de beijar"”. (SANTIAGO, 1976, p. 114)

Apesar de, como vimos, o estudo de Silviano Santiago resvalar no mesmo interesse dos outros trabalhos de nosso corpus ao buscar, no texto literário, as representações das contradições sociais, há uma diferença importante entre o trabalho de Silviano Santiago e os de Costa Lima e Schwarz, e que diz respeito às figurações da sexualidade. Silviano Santiago não valoriza essa tensão em si mesma, mas como figuração desse sujeito que se aliena e se separa do grande outro. Nesse sentido, essa maturidade concebida dentro do tempo da 
escritura também tem o seu valor positivo, já que o crítico chega a afirmar que "mais rico é o poema quanto maior for a dívida" (SANTIAGO, 1976, p. 105), sendo a dívida definida como “dívida contraída para com a origem, para com o Pai”, contudo,

se a palavra-da-origem é dívida contraída pelo "ser", é ela ao mesmo tempo crédito seguro para o poema e só para ele. [...] Assumir plenamente a palavra originária é o desejo de apagar (englobando) todo resquício da palavracomeço. (SANTIAGO, 1976, p. 105)

Em posse desse crédito seguro, depois chamado pelo crítico de "crédito puro", o poema se constitui como escritura. Com isso, o crítico parece querer conciliar tanto a valorização da novidade, da ruptura com a palavra do pai gerada no que chama de "espaços de exclusão", tal como vemos valorizar o poema "Infância", quanto o que chama de palavra herdada e que aparece mais fortemente em "Escritório". Nesse sentido, se por um lado há uma afirmação de autonomia da literatura, pois sua leitura se dá a partir de imagens dos próprios poemas, por outro lado, essas imagens são articuladas entre si ao longo de sua obra e valorizadas ou não a partir de elementos heterônomos, quais sejam, a partir de sua capacidade em se constituir como analogia da fala sujeita à análise psicanalítica.

\section{Fundamentos da investigação literária}

Passemos agora ao problema do valor literário no trabalho de Eduardo Portella, em Fundamentos da investigação literária (1974). Aqui, ele é fundamentalmente atribuído dentro de uma lógica segundo a qual o texto será bom conforme ele se constitua como entre-texto, oposto à linguagem comercial do jingle e dotado de uma "ambigüidade estrutural" que só a leitura qualitativa permitiria ver. Ou seja, aquilo que chama de entre-texto e define como texto literário é um conceito que pressupõe o juízo valorativo sobre os objetos literários e isso porque apenas são assim classificados textos e obras que construiriam uma gramática e uma linguagem próprias, distantes daquelas convencionais, do cotidiano. Nesse sentido, se Portella assina o único trabalho que não passa por obras completas, elas estão nele pressupostas, na medida em que um autor estreante dificilmente assinaria um texto que já fosse considerado com um "estilo próprio", com uma linguagem capaz de construir uma obra. Nesse sentido, esse estudo é aquele em que menos a análise literária está presente e que, portanto, a reflexão do valor literário também.

Do ponto de vista do valor literário, poderíamos dizer que Portella seria, sem dúvida nenhuma, o maior defensor, dentre os trabalhos de nosso corpus, dos valores literários que afirmam a autonomia do objeto literário. Isso se dá porque, apesar da brevidade de suas 
análises, o crítico será o único que o irá afirmar como valor literário central, e não periférico como nos outros estudos. Ora, todos os trabalhos vão defender de alguma forma critérios específicos de compreensão e julgamento do objeto literário. Contudo, na prática, vimos que essa especificidade tende a ficar em segundo plano, dando lugar a valores heterônimos, em especial ligados à representação das contradições sociais. Nesse sentido, apesar de a análise de Portella não exibir operadores de leitura da estilística, da linguística, de teorias literárias, etc., o eixo de sua análise e valoração é a identificação do entre-texto como linguagem capaz de engendrar a língua, de romper e produzir ideologias, de modo que ele acaba sendo sua própria referência de produtividade, não afirmando sua qualidade por algo externo a ele (leitura do país, da casa grande, de uma cultura nacional, etc.).

Pois bem, essa forma de afirmação de valores ligados à autonomia do objeto literário coincide, como comentamos anteriormente, com a escolha por falar sobre poesia e/ou prosa, com o fato de que Portella será o único crítico a escolher, dentro de nosso corpus, a poesia do século XIX - época marcada por despertar interesse principalmente por seus prosadores - e o que seriam prosas tidas como poéticas no século XX, tal como a de Guimarães Rosa e Clarice Lispector. Essa valorização da constituição de uma linguagem capaz de se autorreferenciar se dá em "Navio negreiro", "Buriti” e Uma aprendizagem ou livro dos prazeres (1969), além disso, essa autorreferência, por sua vez, sempre está vinculada ao pré-texto, ou seja, a elementos heterônomos. É justamente essa tensão que estará presente na atribuição de valor literário. Todos os três textos são avaliados por aquilo que não realizam, vamos dizer assim, e por aquilo que realizam. Como disse a respeito da sobredeterminação presente na poesia abolicionista de Castro Alves: "tudo isso Castro Alves ordenou em torno de antigas palavras (liberdade, humanidade, esperança), que agora recebiam a carga nova de sobredeterminação" (PORTELLA, 1974, p. 77).

O poema "Navio Negreiro", de Castro Alves, é elogiado por apresentar oposições que desmontam a "ideologia escravocrata", a "ideologia da submissão" (PORTELLA, 1974, p. 92), e instaurariam uma nova ideologia. Na primeira parte do poema, a imagem do albatroz já marcaria a presença da liberdade e, na segunda, "o nauta representa a oposição ao imobilismo, ao lugar fixado, ao sistema limitado" (PORTELLA, 1974, p. 85). Neste início, já prepararia a subversão do "sistema de signos escravocratas", que começa a ocorrer na terceira parte e segue até a última, a sexta, na qual chega-se ao ápice da negação num verso como "Colombo! Fecha a porta dos teus mares" (ALVES apud PORTELLA, 1974, p. 93), em que temos a derrocada do descobrimento como projeto civilizacional positivo. Assim, segundo Portella (1974), ao reter a realidade brasileira ao nível do fatual, aumentando esse repertório e 
produzindo novos sentidos para esses fatos (cf. PORTELLA, 1974, p. 108), Castro Alves superaria limites institucionais, submetendo esse nível fatual, da língua, a uma ação reveladora da linguagem, que imporia sua verdade de modo a ser transtemporal, instaurando e rompendo ideologias com um "traçado metafórico-metonímico" que permitiu integrá-la à “estrutura unitária do tempo" (PORTELLA, 1974, p. 130): passado, presente e futuro, cuja integração é a ideologia que define o que o crítico deve encontrar.

A novela "Buriti", de Guimarães Rosa, também seria de qualidade, pois cria outras gramáticas e não é só engendrada por elas. Segundo Portella (1974), nessa novela, a dissolução das "estruturas sintáticas convencionais" serve de mecanismo "desrealizador ou alegorizante" (PORTELLA, 1974, p. 94), em especial dos locativos, como Buriti, para ele, termo central da dinâmica narrativa da novela:

A função adverbial enquanto mecanismo lingüístico se quebra, transforma, para apropriar-se de uma dimensão criadora que não está refletida na mera funcionalidade do idioma [...]. A dinâmica narrativa se vê no espelho do locativo; que constrói sistema em torno do Buriti. (PORTELLA, 1974, p. 95)

Já o romance Uma aprendizagem ou livro dos prazeres (1969), de Clarice Lispector, também é elogiado por meio de uma passagem em que a locução "apesar de" sofre uma desestruturação sintática e é revitalizada pela linguagem (cf. PORTELLA, 1974, p. 98): “Lóri: uma das coisas que aprendi é que se deve viver apesar de. Apesar de, se deve comer. Apesar de, se deve amar. Apesar de, se deve morrer. Inclusive, muitas vezes é o próprio apesar de que nos empurra para frente" (LISPECTOR apud PORTELLA, 1974, p. 93).

No âmbito do valor literário, a produção e o acontecimento da Semana de 1922 aparecem em alta conta no cânone de Portella, aliás, como exemplo de originariedade. Nela, o novo passaria a ser a "forma como a linguagem engendra temporalização originária", dando "mais autonomia às forças determinantes da própria sociedade". Assim, a novidade não pode ser um valor positivo em si mesma, pois é sempre uma renovação (cf. PORTELLA, 1974, p.16). Nesse sentido, o bom poema tem uma "trama originária", no caso da "retórica da ideologia castroalviana", um movimento que é "metalinguagem ativa", bifurcada em dois eixos que se comunicam: o da linguagem, em que é afirmado o valor positivo da representação da liberdade dos escravos, e o da língua, na qual essa afirmação se dá em relação aos elementos da sociedade escravocrata (cf. PORTELLA, 1974, p. 82).

Sem sombra de dúvida, o trabalho de Portella é aquele que mais profundamente opera com valores literários marcados pela ruptura romântica, pois não estão pautados pelas ideias de coesão, clareza, adequação, naturalidade etc., e seria aquele que mais defende a autonomia da arte. Contudo, ele é justamente o que menos espaço dá ao problema do valor literário e isto 
também se dá porque, sendo o fundamento da investigação literária ao mesmo tempo o fundamento da investigação do entre-texto, eleger um objeto literário de análise já é afirmá-lo com bom. A análise não problematiza o valor, senão o pressupõe dado pelo senso comum em torno daquelas obras e assinaturas.

Por fim, também é importante frisar que, do ponto de vista do valor literário, há a afirmação de autonomia do ficcional na exigência da arte como figura de verdade. $\mathrm{Na}$ perspectiva do crítico, num contexto em que haveria uma suposta vitória da cultura de massa, seria necessário notar que o homem é o núcleo irradiador de todos os valores e um texto literário só pode ser julgado como bom se conseguir fazer frente à ciência como única figura de verdade. Para tanto, o texto literário deve também apresentar um tempo absolutamente antagônico ao da alienação, da máquina, do não humano, enfim, de todas as manifestações da cultura de massa e da propaganda. Como vimos no capítulo anterior, também no âmbito do valor literário, sua reflexão passa por um alto grau de indeterminação histórica, sendo a capacidade de um texto literário de transcender a sua época o que define sua maior ou menor força libertadora como linguagem, definida por ser "o mais concentrado modo de ser da realidade”, "ilimitada liberdade”, "poder libertário" (PORTELLA, 1974, p. 72-75). 


\subsection{Observações gerais}

No capítulo anterior, investigamos diferentes compreensões do objeto literário e, quando o fizemos, sem dúvida o problema do valor literário se colocou na própria tessitura daquelas construções analíticas. Pudemos notar, primeiramente, que o valor literário já era evidentemente central nos trabalhos dos críticos do nossos corpus, a saber: na construção da historiografia dialética de Schwarz, na medida em que a segunda fase de Machado só é síntese enquanto é tida como literariamente superior; para Costa Lima, na ideia de que apenas o romance A Menina Morta (1954), de Cornélio Penna, realizaria, por sua qualidade, o maior número de possibilidades do nível paradigmático; para Merquior, no papel que os "poemas filosófico-existenciais" teriam na inserção da obra de Drummond no cânone ocidental; na ideia de escritura de Silviano Santiago, que pressupõe uma relação íntima com um juízo de valor no que diz respeito aos poemas que conseguiam ou não se constituir como tais; e, por fim, no caso do trabalho de Portella, na ideia de que a fenomenologia do literário só tem existência se o objeto analisado se constitui como linguagem, entre-texto, ou seja, se é tido como de qualidade.

Ora, é óbvio que todo crítico submete o texto às suas categorias de compreensão do mundo, valores literários, percepções de escrita etc. No entanto, não é nem um pouco óbvia a coincidência que encontramos entre eles no que toca a certa tendência ao respeito do cânone literário da época, evidenciado pela escolha dos objetos literários analisados nos ensaios e teses. Dessa forma, há uma certa obediência à relevância a priori da literatura do século XIX e do modernismo e, como observamos na primeira parte do capítulo, a valorização desses dois períodos é acompanhada da valorização dos objetos literários assinados por Machado de Assis, Guimarães Rosa, Clarice Lispector, Drummond e Cabral.

Nesse sentido, demos especial destaque ao período tido por contemporâneo, cujo breve panorama tornou clara a precariedade ou a ausência do tratamento desses objetos literários em detrimento da pluralidade e profundidade daquele reservado aos objetos literários pertencentes aos períodos ao quais nos referimos acima. Fala-se em literatura sem qualidade após o modernismo, mas poderíamos também pensar que, entre tantos elementos envolvidos nisso, um deles seria que os critérios empregados para valorizar Guimarães ou Drummond não serviriam de parâmetro para julgar as poesias concretista e marginal, hipótese levantada em discursos autocríticos da crítica ${ }^{56}$. Assim, foi de particular importância para este

56 “Agora, evidentemente, a gente também faz parte desta tradição e quando você lê um poeta hoje, você tem na cabeça um Drummond, Mallarmé, uma tradição longuíssima, você tem Virgílio e Homero na cabeça. Então 
capítulo o trabalho de Lucius Provase, "Da experiência de escrever ao ato de escrita: vida e arte na poética de Cacaso" (2010), que propõe categorias de análise particulares à poesia marginal, particularmente a de Cacaso, como a de "vida" ou de "deslocamento enunciativo". Tal como o ensaio de Silviano Santiago, ainda que não faça comparações com os concretistas, o autor aponta marcas importantes da construção da radicalidade dessas poesias dentro do seu próprio projeto. Independentemente do valor literário que se possa atribuir a elas, não se dispor a entendê-las nos seus próprios tempos ou projetos é relegá-las injustamente ao não existente, à antipoesia, antiliteratura ou antiarte, ou seja, a um valor literário negativo a priori, pois inviabiliza, a longo prazo, a discussão desses objetos, já que foram, no fundo, deslegitimados como tais.

Por fim, caberia notar que, tanto a predominância de objetos literários tidos por nacionais como a divisão entre os períodos literários apontam uma tendência a uma afirmação geral de um cânone historiográfico nacional. Nesse sentido, chamou a atenção, como no segundo capítulo, o papel da concepção da literatura como representação. Tanto nos trabalhos em que isso está presente em seus projetos como naqueles em que isso escapa, a representação das contradições sociais é valorizada positivamente. Essa característica não pode ser relacionada diretamente a outras, por exemplo, a predominância de valores clássicos como a coerência, a coesão, a unidade, a naturalidade etc. bem como uma tendência a evitar temas baixos como a sexualidade, com exceção do trabalho de Silviano Santiago. No entanto, sua presença, junto com elementos como esses e a concepção historiográfica romântica, deixariam entrever uma espécie propensão mais geral, no que toca à atribuição de valor literário, à conservação de pontos cruciais também para a crítica literária anterior às décadas de 1960 e 1970.

quando você vai ler, você fala: o que esse cara tá propondo? A gente tem muito uma idéia modernista, moderna, de que a poesia deveria ser o novo, a cada momento o novo. Num mundo administrado como o nosso e que vive um presente contínuo da troca, a gente deveria perguntar se existe condição de aparecer o novo. Ou se a própria idéia de novo não é a reposição contínua da própria estrutura de troca mercantil que a gente vive. Se o novo já não tá controlado previamente pela estrutura do capital." (HANSEN, 2005) 


\section{Considerações finais}

De modo geral, conclusões e introduções costumam dar margem a mal-entendidos, assim, aqui faremos apenas uma reflexão mais geral sobre a ligação entre os capítulos, bem como um breve esforço de retomada do que dissemos anteriormente. Inicialmente, é importante ressaltar que a separação entre as reflexões gerais sobre o conceito de campo literário e $\mathrm{o}$ apontamento de perspectivas teóricas e valores literários responde fundamentalmente à necessidade de organização da exposição da pesquisa. A ideia era menos colocar um "contexto" para a construção das teses que analisamos do que uma tentativa de especular, a partir da trajetória das assinaturas do nosso corpus principal, sobre o modo de funcionamento do campo literário naquele momento. Nesse sentido, nosso interesse não era avaliar a qualidade desses trabalhos e criar uma hierarquia entre eles, muito menos pôr suas supostas inserções numa história sem fronteiras nacionais da teoria e da crítica literária. A ideia aqui era tentar suspender ao máximo o juízo sobre esses trabalhos para focar na descrição de traços comuns e diferenças entre eles.

Outra ressalva a ser feita sobre o vínculo do primeiro capítulo com os outros é que seria um contrassenso pensá-lo como elemento que determinaria a produção dos trabalhos, pois foi justamente a comparação entre eles que nos permitiu, por indução, imaginar um campo literário. De todo modo, se esse primeiro capítulo ressoa ao longo deste trabalho é porque a oposição entre autonomia e heteronomia do literário está em seu cerne. Tanto no âmbito teórico como valorativo, notamos sua presença, indicando, inclusive, uma frequência maior dos elementos do polo da heteronomia literária do que aquela descrita por Bourdieu.

Os trabalhos de Costa Lima, Silviano Santiago e Portella foram tidos como aqueles que mais afirmam a autonomia do ficcional, justamente por seus projetos apresentarem diferentes formas de recusa da literatura como representação das contradições sociais. Nessa direção, Costa Lima se atém a definir o paradigma interno da obra de Cornélio Penna; Silviano Santiago se dedica à escritura drummondiana; e Portella se detém no que entendem serem as linguagens de Castro Alves, Guimarães Rosa e Clarice Lispector . Em todos os três casos, o entendimento da literatura ganha sentido e valor por constituir o paradigma, uma escritura e uma linguagem, respectivamente, e não por representar contradições sociais, ainda que essa concepção do objeto literário esteja presente.

Dado isso que lhes "escapa", contudo, os cinco estudos que compõem o nosso corpus principal, ainda que com intensidades e funções diferentes, apresentam uma concepção da literatura como representação de contradições sociais que estão dadas, sem produzir outro tipo 
de saber ou de saber sobre si própria. Dentro dessa perspectiva, a literatura é instrumento de compreensão de uma verdade estabelecida por outra discursividade e o discurso ficcional é, no fundo, sempre colocado em segundo plano, tendendo à indisposição analítica e/ou ao destaque do tema e certa tendência ao conteudismo nas análises. O trabalho de Silviano Santiago é aquele que mais eleva o discurso ficcional, dada a incorporação de imagens literárias na construção da autoridade da sua linguagem analítica, entre outros elementos; e, saindo do recorte temporal que propusemos, também destacamos todo o esforço posterior de Costa Lima, que permanece até os dias de hoje, de pensar as ideias de mimesis, representação, controle do imaginário, sujeito fraturado etc.

De todo modo, no caso das teorias, as semelhanças foram identificadas muitas vezes pontualmente e à revelia dos projetos dos autores. Contudo, no capítulo sobre o valor literário, as semelhanças saltavam à vista. Sem dúvida, isso tem relação com outro elemento comum aos trabalhos, que é a manutenção da ideia de obra como unidade (ainda que subdividida em partes e em diferentes estilos, dado que a busca por um fio que as liga se mantém), e mesmo no caso do trabalho de Portella, que não analisa obras, ela esteve presumida de modo crucial. Em todo o caso, a preocupação com o estudo de uma obra ou pressuposição dela é um indício de que esses trabalhos se viam contribuindo, no fundo, para uma história da literatura nacional - como se estudar uma obra fosse já legitimar seu estudo como o de um objeto sério, bem como o objeto só ganha seriedade apenas enquanto se constitui como obra.

Nesse sentido, parece que ainda na década de 1970, assim como no século anterior, era mais importante divergir em relação ao que o texto literário representaria e menos à maneira com que representaria. $\mathrm{O}$ crescente prestígio da tese acadêmica naquele período talvez tenha implicado uma centralidade desse gênero discursivo em detrimento da crítica literária e do procedimento de explicitação da atribuição do valor literário que também a caracteriza. Com isso, queremos dizer que a crítica literária é menos um gênero textual particular do que uma "postura" em relação ao texto literário, que se preocupa quanto à atribuição e aos critérios de reconhecimento de valor literário, e que independe da forma que se adota para escrevê-la, seja uma tese acadêmica, um artigo, uma resenha, um ensaio etc. No limite, inclusive, teríamos teses mais próximas de uma crítica literária, pois deixam escapar seus juízos pela dissertação, do que críticas, por exemplo, parafrásticas (frequentemente confundidas com resenhas) e que têm a convicção de que seu dever é informar o leitor de modo neutro sobre o conteúdo do livro.

Ao longo de nossa pesquisa, a impressão que tivemos é que a valorização da literatura e a disposição para a discussão do valor literário parece se dar em proporções semelhantes, dado que a literatura aparenta perder prestígio dentro e fora do campo literário justamente 
numa época em que nunca havia se produzido um número tão grande de teses sobre literatura. O problema do valor literário parece implicar, nesse sentido, mais diretamente uma visão da teoria literária que ultrapasse a racionalidade técnica de modo a fazê-la dialogar com as outras discursividades do seu tempo. Com isso, queremos dizer que esse problema se liga, na modernidade, não ao cumprimento de uma regra institucionalizada em preceptivas retóricas, mas a uma ideia geral de negatividade, no sentido de construção retórica da negação das ordens estabelecidas. É pensando nessa ideia geral de modernidade que devemos lembrar que um capítulo sobre valor literário é necessariamente um capítulo sobre o valor da literatura, já que a relevância e a pertinência deste pressupõe a relevância e a pertinência da própria literatura.

O problema do valor literário também está relacionado a uma ideia de literatura como atividade cultural entre outras e não particular e autorreferenciada a partir de sua própria história e cuja versão oficial está sob o domínio universitário. Todos os críticos aqui entendem seu trabalho de crítica literária como sendo de crítica cultural mais ampla, ainda que haja disputa em torno do interesse e da relevância em se falar de uma cultura nacional ou planetária. Essa concepção parece destacar a arte literária e, de alguma forma, tanto a visão desta como instrumento de educação revolucionário, como desabafo, como denúncia etc. quanto a visão da literatura como sistema, fundadora de uma ciência da literatura, etc. Enfim, todas essas finalidades que parecem ir contra os interesses da autonomia da arte, ou seja, "propriamente literários", eram fundamentais para dar sentido e pertinência ao objeto literário. O que parecia externo aos seus interesses, poderia ser, visto de outro ângulo, tanto aquilo que afirma sua pertinência, ao ser exemplo de uma tese não literária, quanto aquilo que afirma sua completa dispensabilidade, já que seria só um meio para se chegar na discursividade que interessa: uma teoria sociológica, psicanalítica, antropológica, etc.

Contudo, no caso em que a literatura é exemplo de uma tese não literária, a pertinência é cultural e só existe referenciada a outra discursividade e, no caso em que justamente isso a torna dispensável, a "dispensabilidade" parece ser mais propriamente artística, já que é a qualidade do ficcional e a história de suas técnicas próprias de cada gênero e subgênero que são negligenciadas para servirem de documento histórico, discurso mítico, fala a ser analisada psicanaliticamente ou um exemplo de uma teoria literária. Há então, no que parece ser uma balança equilibrada, como se pode ver, um peso muito mais leve sobre o prato da valorização artística do literário e que pode ser entrevista tanto na pouca presença de elementos que valorizam a autonomia do ficcional nos trabalhos como na tendência a negligenciar o problema do valor literário. 


\section{Bibliografia}

ACADEMIA BRASILEIRA DE LETRAS. Rio de Janeiro: Academia Brasileira de Letras, 2012. José Veríssimo: Biografia. Disponível em: $<$ http://www.academia.org.br/abl/cgi/cgilua.exe/sys/start.htm?infoid=780\&sid=203>. Acesso em: 17 out. 2012.

ADORNO, T. W. Notas de literatura I. São Paulo: Duas Cidades; Ed. 34, 2003. (Coleção Espírito Crítico)

AGUIAR, F.; VASCONCELOS, E. G. Ángel rama: literatura e cultura na América Latina. Tradução de Raquel La Corte dos Santos e Elza Gasparotto. São Paulo: Edusp, 2001 .

ALVES, C.; VARELA, F. Vozes d'África. Navio Negreiro. Cântico do Calvário. Rio de Janeiro: Livraria Acadêmica de J. G. de Azevedo, [s.d.] Disponível em: $<$ http://www.brasiliana.usp.br/bbd/handle/1918/01814300\#page/13/mode/1up $>$. Acesso em: 17 out. 2012.

ANDRADE, M. Obra Imatura. 3. ed. São Paulo: Livraria Martins Editora S.A.; Belo Horizonte: Editora Itatiaia Limitada, 1980.

ASSIS, M. Machado de Assis: obra completa. Rio de Janeiro: Editora José Aguilar, 2004.

ASSOCIAÇÃO DOS DOCENTES DA USP. O controle ideológico na USP (1964-1978). São Paulo: Adusp, 2004.

BARBOSA, J. A. A tradição do impasse. São Paulo: Ática, 1974.

BARROS, E. M. C. Política de Pós-graduação no Brasil (1975-1990): um estudo da participação da comunidade científica. São Carlos: Edufscar, 1998.

BARTHES, R. Crítica e verdade. Tradução de Leyla Perrone-Moisés, São Paulo: Perspectiva, 2007.

BOSI, A. Os estudos literários na era dos extremos. Rodapé. São Paulo, n. 1, p. 170-5, nov. 2001.

BOURDIEU, P. O poder simbólico. Lisboa: Diefel, 1989. 2001

Meditações pascalinas. Tradução de Sérgio Miceli. Rio de Janeiro: Bertrand Brasil,

. A Economia das Trocas Simbólicas. São Paulo: Perspectiva, 2004.

As regras da arte. 2. ed. São Paulo: Companhia das Letras, 2005a.

Razões práticas: sobre a teoria da ação. 7. ed. Campinas: Papirus, 2005 b.

Distinção-crítica social do julgamento. São Paulo: Edusp, 2008.

BRITO, A. C. Bota na conta de Galileu se ele não pagar nem eu. Opinião, São Paulo, p. 20-1, 28 de nov. de 1975.

Beijo na boca e outros poemas. São Paulo: Duas Cidades, 1985. 

1997.

CAMPOS, A.; CAMPOS, H.; PIGNATARI, D. Teoria da poesia concreta: textos críticos e manifestos 1950-1960. São Paulo: Livraria Duas cidades, 1975.

CANDIDO, A. A formação da literatura brasileira. São Paulo: Itatiaia, 1981.

. O método crítico de Silvio Romero. São Paulo: Edusp, 1988.

. Vários escritos. 3. ed. revista e ampliada. São Paulo: Duas Cidades, 1995.

A educação pela noite. São Paulo: Ouro Sobre Azul, 2006.

CARDOSO, I. Universidade da comunhão paulista. Coleção Educação Contemporânea, Série Memória da Educação, São Paulo: Cortez Editora / Editora Autores Associados, 1982.

A geração dos anos de 1960: o peso de uma herança. Tempo Social. São Paulo, vol. 17, n. 2, p. 93-107, nov. 2005.

CÉSAR, A. C. Os professores contra a parede. Opinião, São Paulo, p. 20-1, 12 de dez. de 1975.

CHARTIER, R.; LOPES, J. S. L. Pierre Bourdieu e a história. Debate com José Sérgio Leite Lopes. Topoi. Rio de Janeiro, p. 139-182, mar. 2002.

COSTA LIMA, L. Por que literatura. Petrópolis: Vozes, 1966.

Estruturalismo e teoria da literatura: introdução às problemáticas estética e sistêmica. Petrópolis: Vozes, 1973.

. Lira e antilira: Mário, Drummond, Cabral. Rio de Janeiro: Civilização Brasileira, 1968.

. Metamorfose do silêncio (análise do discurso literário). Rio de Janeiro: Editora Eldorado, 1974.

Bloco do eu sozinho. Opinião, São Paulo, p. 20-1, 12 de dez. de 1975.

. A perversão do trapezista. Rio de Janeiro: Imago Editora, 1976.

.Dispersa demanda. Rio de Janeiro: Francisco Alves, 1981.

Sobre a questão da mímesis: carta a Roberto Schwarz. Novos Estudos - CEBRAP, n. 33, jul. de 1992.

Vida e mímesis. Rio de Janeiro: 34 Letras, 1995.

O que chamamos crítica literária?. Veredas - Revista Cultural do Banco do Brasil, n. 90 , jun. de 2003 .

Questões sobre uma cultura periférica. In: LOPES, A. H.; CALABRE, L. (Org.), Diversidade cultural brasileira. Rio de Janeiro: Edições Casa Rui Barbosa, 2005.

COUTINHO, C. N. Literatura e humanismo. Rio de Janeiro: Paz e Terra, 1967. 
O estruturalismo e a miséria da razão. Rio de Janeiro: Paz e Terra, 1972.

. Há alguma teoria com medo da prática. Opinião, São Paulo, p. 20-1, 28 de nov. de 1975.

DANTAS, V; SIMON, I. M. Poesia ruim, sociedade pior. Novos estudos CEBRAP. São Paulo, n. 12, p. 48-61, jun. 1985.

DERRIDA, J. A escritura e a diferença. São Paulo: Perspectiva, 1995.

DRUMMOND DE ANDRADE, C. Carlos Drummond de Andrade: obra completa. Rio de Janeiro: Nova Aguilar, 2003.

EAGLETON, T. A função da crítica. São Paulo: Martins Fontes, 1991.

Depois da teoria: um olhar sobre os Estudos Culturais e o pós-modernismo. Tradução: Maria Lucia Oliveira. Rio de Janeiro: Civilização Brasileira, 2005.

FOUCAULT, M. O que é um autor? Tradução de António Fernando Casais e Edmundo Cordeiro, 2. ed., Coleção Passagens, Lisboa: Vega, 1992.

- A arqueologia do saber. Tradução de Luiz Felipe Baeta Neves, Petrópolis: Vozes, 1972.

FRANCO, M. S. C., As idéias estão no lugar. Cadernos de Debate, n. 1, São Paulo: Brasiliense, 1976.

FRYE, N. Anatomia da crítica. São Paulo: Editora Cultrix, 1957.

GALVÃO, W. N. Desconversa. Rio de Janeiro: UFRJ, 1998.

GUMBRECHT, H. U. A tarefa das ciências humanas hoje. Floema, ano 1, n. 1, p. 63-87, out. 2005. Tradução de Flávia Aninger de Barros Rocha e Márcio Roberto Soares Dias.

HALLEWELL, L. O livro no Brasil. São Paulo: Edusp, 2005.

HANSEN, J. A. Barroco, neobarroco e outras ruínas. Tereza, n. 2, São Paulo, Editora 34, p. 10-66, 2001.

. O espanador de múmias. Entrevista feita por Edson Cruz e Oliveira Barbosa, portal Cronópios, 05 de jul. de 2005, Disponível em: $<$ http://www.cronopios.com.br/site/artigos.asp?id=316>. Acesso em: 23 set. 2012.

HEIDEGGER, M. Ser e tempo. Tradução de Márcia Sá Cavalcante Schuback. 2. ed. Petrópolis: Vozes; Bragança Paulista: Editora Universitária São Francisco, 2007.

HOLANDA, S. B. Raízes do Brasil. 26. ed. São Paulo: Companhia das Letras, 2004.

IVO, L. A morte da literatura brasileira. O Globo, 23 jun. 1975. (Suplemento literário)

JACOBY, R. Os últimos intelectuais: a cultura americana na era da academia. São Paulo: Trajetória Cultural/EDUSP, 1990.

KOSELLECK, R. Crítica e crise. Rio de Janeiro: Eduerj/Contraponto, 1999.

LAFETÁ, J. L. 1930: a crítica e o modernismo. 2. ed. São Paulo: Duas Cidades; Ed.34, 2000. 
LÉVI-STRAUSS, C. Introdução à obra de Marcel Mauss. In: . Sociologia e antropologia. São Paulo: Cosac Naify, 2003.

. Origem dos modos à mesa. São Paulo: Cosac Naify, 2004.

. Antropologia estrutural. São Paulo: Cosac Naify, 2008.

. O pensamento selvagem. Campinas: Papirus, 2007.

. Tristes trópicos. São Paulo: Companhia das Letras, 2010.

LIMA, R. E. O ensaio na crítica literária contemporânea. Revista de Estudos de Literatura, Belo Horizonte, v.3, p. 35-42, out. 1995.

. A crítica literária na universidade brasileira. 1997. 340f. Dissertação (Literatura comparada). 340f. Tese (Literatura comparada) - Universidade Federal de Minas Gerais, Belo Horizonte, 1997.

LISPECTOR, C. Uma aprendizagem ou livro dos prazeres. Rio de Janeiro: Rocco, 1998.

MARTINS, W. A crítica literária no Brasil. 2. ed. São Paulo: Francisco Alves, 2003.

MERQuior, J. G. M. Arte e sociedade em Marcuse, Adorno e Benjamin: ensaio crítico sobre a escola neohegeliana de Frankfurt. Rio de Janeiro: Tempo Brasileiro, 1969.

. A estética de Lévi-Strauss. Rio de Janeiro: Tempo Brasileiro, 1975a.

. O estruturalismo dos pobres e outras questões. Rio de Janeiro: Tempo Brasileiro, $1975 b$.

. Verso universo em Drummond. Tradução de Marly de Oliveira, Rio de Janeiro: José Olympio; Secretaria de Estado de Cultura, Ciência e Tecnologia, 1975c.

MICELI, S. Intelectuais à brasileira. São Paulo: Cia das Letras, 2001.

MIRANDA, W. M (Org.). Navegar é preciso, viver. Belo Horizonte: UFMG, 1997.

MOTTA, L. T. Sobre a crítica literária brasileira no último meio século. Rio de Janeiro: Imago, 2002.

NITRINI, S. Departamento de Teoria Literária e Literatura Comparada. In: Informativo da Faculdade de Filosofia, Letras e Ciências Humanas - USP. Informe. N. 10. São Paulo: Faculdade de Filosofia Letras e Ciências Humanas, abril/2004. P.15-21.

NUNES, B. Critica literária no Brasil, ontem e hoje. In: MARTINS, M. H. (Org.), Rumos da Crítica. São Paulo: Editora SENAC; Itaú Cultural, 2000.

A clave do poético. São Paulo: Cia. das Letras, 2009.

PASTA Jr., J. A. Enquete: José Antonio Pasta Junior. Rodapé. São Paulo, n. 2, p.16-19, ago. 2002.

PENNA, C. Cornélio Penna: romances completos. Rio de Janeiro: Editora José Aguilar, 1958. 
PEREIRA, J. M. O fenômeno Merquior. 2001. Homepage de Olavo de Carvalho. Disponível em: <http://www.olavodecarvalho.org/convidados/0122.htm>. Acesso em: 16 out. 2010.

PERELMAN, C.; OBBRECHTS-TYTECA, L. Tratado de argumentação: a nova retórica, Trad. Maria Ermantina Galvão G. Pereira. São Paulo: Martins Fontes, 1996.

PERRONE-MOISÉS, L. Texto, crítica, escritura. São Paulo: Ática, 1978. (Ensaios, 45)

. História literária e julgamento de valor. Colóquio Letras. Lisboa, n. 77, p.24-41, jan. 1984.

A crítica literária hoje. In: Cânones e contextos $-5^{\circ}$ Congresso Abralic - Anais. Rio de Janeiro: ABRALIC, 1997, p.86.

. Que fim levou a crítica literária? Folha de S. Paulo, São Paulo, 25 ago. 1996. Caderno Mais!, p. 9.

PIGNATARI, D. Poesia pois é poesia: 1950-2000. São Paulo: Ateliê Editorial; Campinas: Editora da Unicamp, 2004a.

. Semiótica e literatura. Cotia: Ateliê Editorial, 2004b.

PONTES, H. Destinos mistos. São Paulo: Cia. das Letras, 1998.

PORTELLA, E. Dimensões III. Rio de Janeiro: Tempo Brasileiro, 1965.

. Literatura e realidade nacional. 2. ed. Rio de Janeiro: Tempo Brasileiro, 1971.

. Fundamentos da investigação literária. Rio de Janeiro: Tempo Brasileiro, 1974.

. Teoria da comunicação literária. Rio de Janeiro: Tempo Brasileiro, 1976.

. Vanguarda e Cultura de Massa. Rio de Janeiro: Tempo Brasileiro, 1978.

. Política de Educação e Cultura. Rio de Janeiro: Escola Superior de Guerra, 1979.

. Sede de saber - Eduardo Portella (Parte I). Entrevista a Sebastião Amoêdo. Rio

de Janeiro: Universidade do Brasil, 2011. Vídeo. Disponível em:

$<$ http://www.youtube.com/watch?

$\mathrm{v}=\mathrm{u} 44 \mathrm{cSBUPp} 8 \&$ list=FLJQAikBXab7tOi3QVnlagbw\&index $=1 \&$ feature=plpp_video $>$ Acesso em: 9 mai. 2012.

PROVASE, L. Da experiência de escrever ao ato de escrita: vida e arte na poética de Cacaso. 2010. Dissertação (Mestrado em Teoria Literária e Literatura Comparada) Faculdade de Filosofia, Letras e Ciências Humanas, Universidade de São Paulo, São Paulo, 2010.

PUGLIESI F $F^{o}$, M. T. Presente invenção: lendo romances brasileiros contemporâneos. 2011. (Mestrado em Teoria Literária e Literatura Comparada) - Faculdade de Filosofia, Letras e Ciências Humanas, Universidade de São Paulo, São Paulo, 2011.

ROCHA, J. C. C. Crítica Literária: em busca do tempo perdido? Chapecó: Argos, 2011. 
RODAS, J. A crítica literária na imprensa diária: de 1985 a 2010. In: OLIVEIRA, A. et. al. Deslocamentos críticos. São Paulo: Babel / Itaú Cultural, 2011. p. 159-173.

ROMERO, S. História da Literatura brasileira. v. 6, 6. ed., Rio de Janeiro: Livraria José Olympio Editora, 1960.

- Machado de Assis: estudo comparativo de literatura brasileira, Rio de Janeiro: Laemmert C. $1897 . \quad$ Ditores, Disponível em: $<$ http://www.brasiliana.usp.br/bbd/handle/1918/01615800\#page/1/mode/1up $>$. Acesso em: 17 out. 2012.

ROSA, G. Noites do sertão (corpo de baile). Rio de Janeiro; São Paulo: Editora Record, 1988.

SANTIAGO, S. Carlos Drummond de Andrade. Petrópolis: Vozes, 1976.

. Vale quanto pesa (Ensaios sobre questões político-culturais). Rio de Janeiro: Paz e Terra, 1982.

. Uma literatura nos trópicos. Rio de Janeiro: Roxo, 2000.

. Entrevista concedida a Helena Boleny e Lúcia Lippi Oliveira. In: Estudos Históricos, Rio de Janeiro, n. 30, p. 147-173, 2002.

. O intelectual Silviano Santiago. Entrevista concedida a Eneida Leal Cunha e Wander Melo Miranda. In: CUNHA, Eneida Leal (org). Leituras críticas sobre Silviano Santiago. Belo Horizonte: Editora UFMG; São Paulo: Fundação Perseu Abramo, 2008.

SCHWARZ, R. Ao vencedor as batatas. São Paulo: 1977.

. Entrevista concedida a Gildo Marçal e O. C. Louzada Filho Brandão. 1979. In:

$<$ http://antivalor.vilabol.uol.com.br>. Acesso em: 18 out. 2010.

. Pai de família e outros estudos. 2. ed. Rio de Janeiro: Paz e Terra, 1992a.

. Seqüências brasileiras. São Paulo: Cia. das Letras, 1999.

SEVCENKO, N. Literatura como missão: tensões sociais e criação cultural na Primeira República. São Paulo: Brasiliense, 1985.

SILVA, A.V. A Paraliteratura. In: Teoria Literária, Rio de Janeiro, Tempo Brasileiro, 1979

SOUZA, E. M. Crítica cult. Belo Horizonte, UFMG, 2002.

.Traço crítico: ensaios. Rio de Janeiro: Editora da UFRJ; Belo Horizonte: Editora da UFMG, 1993.

SÜSSEKIND, F. Papéis colados. 2. ed. Rio de Janeiro: UFRJ, 2002.

Literatura e vida literária. Polêmicas, diários e relatos. 2. ed. Belo Horizonte: Editora UFMG, 2004.

VENTURA, R. Estilo tropical - história e polêmicas literárias no Brasil. São Paulo: Cia. das Letras, 1991. 
VERÍSSIMO, J. Estudos de literatura brasileira. $3^{\text {a }}$ série. Belo Horizonte: Itatiaia; São Paulo: Editora da Universidade de São Paulo, 1977.

José Veríssimo: crítica e história literária (seleção e apresentação de João Alexandre Barbosa). Rio de Janeiro: Livros Técnicos e Científicos; São Paulo: Editora da Universidade de São Paulo, 1978.

. História da Literatura Brasileira, 7. ed. Rio de Janeiro: Topbooks, 1998.

WITTGENSTEIN, L. Investigações filosóficas. Tradução de José Carlos Bruni. 3. ed. São Paulo: Abril Cultural, 1984. 